\title{
FIELD STUDY OF DISPOSED WASTES FROM ADVANCED COAL PROCESSES
}

DOE Quarterly Technical

Progress Report

February 1992 to April, 1992

\author{
Prepared by: \\ Radian Corporation \\ 8501 Mo-Pac Boulevard \\ P.O. Box 201088 \\ Austin, Texas 78720-1088 \\ Prepared for: \\ Jerry L. Harness \\ Department of Energy \\ Morgantown Energy Technology Center \\ 3610 Collins Ferry Road \\ P.O. Box 880 \\ Morgantown, West Virginia 26505
}

Distribution:

Report Receipt (Mail Stop F07), DOE/METC (3)

Ray Butler, EERC

Andrew Covar/4

Larry Holcombe/4

Andy Weirherg/4

Tôm Dỡ: PRI

Jerry Walker, Colorado Ute

Wayne Bahr IL/ENR 


\title{
FIELD STUDY OF DISPOSED WASTES FROM ADVANCED COAL PROCESSES
}

DOE Quarterly Technical

Progress Report

February 1992 to April, 1992

\author{
Prepared by: \\ Radian Corporation \\ 8501 Mo-Pac Boulevard \\ P.O. Box 201088 \\ Austin, Texas 78720-1088 \\ Prepared for: \\ Jerry L. Harness \\ Department of Energy \\ Morgantown Energy Technology Center \\ 3610 Collins Ferry Road \\ P.O. Box 880 \\ Morgantown, West Virginia 26505
}

Distribution:

Report Receipt (Mail Stop F07), DOE/METC (3)

Ray Butler, EERC

Andrew Covar $/ 4$

Larry Holcombe/4

Andy Weinberg/4

Tom Boyd, EPRI

Jerry Walker, Colorado Ute

Wayne Bahr IL/ENR 
TABLE OF CONTENTS

Page

1.0

OBJECTIVES

1

2.0

SUMMARY OF PREVIOUS WORK $\ldots \ldots \ldots \ldots \ldots \ldots \ldots \ldots$

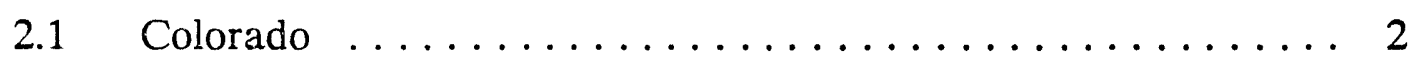

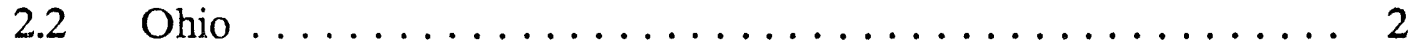

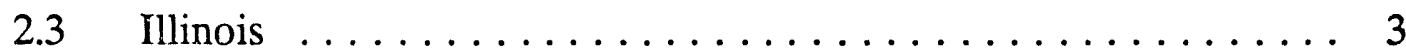

3.0 OBJECTIVES FOR THE CURRENT REPORTING PERIOD . . . . . 4

4.0 ACTIVITIES FOR THE REPORTING PERIOD $\ldots \ldots \ldots \ldots \ldots 6$

$4.1 \quad$ Colorado Ute Site $\ldots \ldots \ldots \ldots \ldots \ldots \ldots \ldots \ldots \ldots$

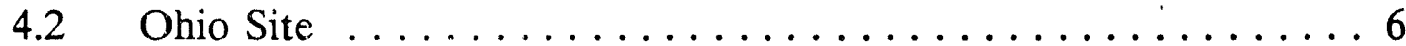

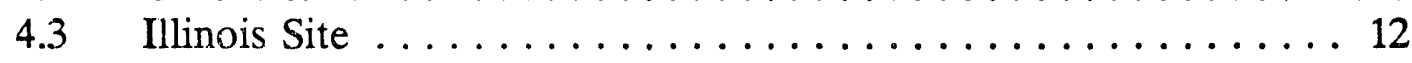

$5.0 \quad$ PROBLEMS ENCOUNTERED $\ldots \ldots \ldots \ldots \ldots \ldots \ldots \ldots \ldots$

6.0 ACTIVITIES PLANNED FOR THE NEXT QUARTER $\ldots \ldots \ldots 27$ 


\section{LIST OF FIGURES}

Page

Major Element Concentrations in Groundwater Samples from Wells Downgradient of the Ohio North Cell for All Sampling Events . . . . . 7

Major Element Concentrations in Groundwater Samples from Wells Downgradient of the Ohio South Cell for All Sampling Events . . . . . 8

Major Element Concentrations in Groundwater Samples from Wells Upgradient of the Ohio Test Cells for All Sampling Events . . . . . . 9

Major Element Concentrations in Porewater Samples from Lysimeters Within the Ohio South Cell

Major Element Concentrations in Groundwater Samples from Wells Upgradient and Downgradient of the Illinois Test Ceil for All

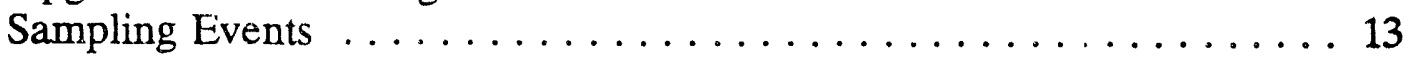

Major Element Concentrations in ASTM Leachate of Ash from the

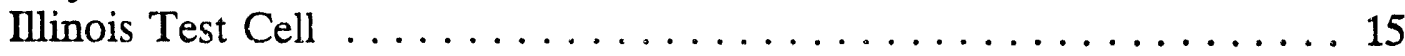

Illinois Test Cell In-Situ Permeability Measuiements $\ldots \ldots \ldots \ldots \ldots 17$

Effects of Fly Ash Addition to Midwest Grains FBC Waste . . . . . . 19

Strength and Permeability of Midwest Grain BFBC Waste/Fly Ash Mixtures After 28 Days Moist Curing . . . . . . . . . . . 20

Results of Thermogravimetric Analysis (TGA) on a Sample of FBC Waste

Results of Thermogravimetric Analysis (TGA) on a Mixture of 75\% FBC Waste and 25\% Fly Ash

Results of Thermogravimetric Analysis (TGA) on a Mixture of 50\% FBC Waste and 50\% Fly Ash

Effects of Increased Initial Water on 14 Day Strength of FBC/Fly Ash Mixtures

Bulk Density and Dry Density of Prepared Samples of FBC/Fly Ash Mixtures 


\section{LIST OF TABLES}

Page

Field Testing - Solid Waste Disposal, X-Ray Diffraction Mineralogy - Ash

Field Testing - Solid Waste Disposal, In-Situ Hydraulic Conductivity Data

Field Testing - Solid Waste Disposal, Physical Testing Data Chemical Characteristics of Liquid From Ohio, Event $10 \ldots \ldots \ldots 35$

Field Testing - Solid Waste Disposal, Physical Testing Data 45

Field Testing - Solid Waste Disposal, In-Situ Hydraulic Conductivity . . 33

Chemical Characteristics of Liquid From Illinois, Event 3

52

Chemical Characteristics of Solid From Illinois, Event $3 \ldots \ldots \ldots 60$

Field Testing - Solid Waste Disposal, X-Ray Diffraction

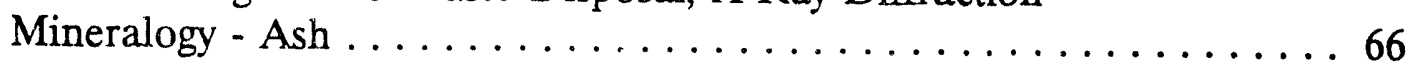

Field Testing - Solid Waste Disposal, In-Situ Hydraulic Conductivity .. 67 
The Department of Energy/Morgantown Energy Technology Center (DOE/METC) has initiated research on the disposal of solid wastes from advanced coal processes. The objective of this research is to develop information to be used by private industry and government agencies for planning waste disposal practices associated with advanced coal processes. To accomplish this objective, DOE has contracted Radian Corporation and the North Dakota Energy \& Environmental Research Center (EERC) to design, construct, and monitor a limited number of field disposal tests with advanced coal process wastes. These field tests will be monitored over a three year period with the emphasis on collecting data on the field disposal of these wastes.

There has been considerable research on the characteristics and laboratory leaching behavior of coal wastes ..- a lesser amount on wastes from advanced coal processes. However, very little information exists on the field disposal behavior of these wastes. Information on field disprisal behavior is needed (a) as input to predictive models being developed, $b$ ) as input to the development of rule of thumb design guidelines for the disposal of these wastes, and c) as evidence of the behavior of these wastes in the natural environment.

\section{SUMMARY OF PREVIOUS WORK}

This study is organized into four major Tasks. Tasks 1 and 2 were devoted to planing the Task 3 field study. Task 4 uses the results of the field testing to produce an Engineering Design Manual for the utilities and industrial users who manage wastes from advanced coal combustion technologies.

Task 1 identified and rated test design options. A Test Design Manual was prepared and submitted to METC in 1988. Specific test procedures suitable for each design option were identified under Task 2 . These test methods were documented in a 
Test Procedures Manual, submitted to METC in 1988. Also under Task 2, test sites were selected and site access was negotiated. Sites in illinois and North Dakota were delayed at this stage, and the North Dakota site was dropped from consideration. Task 2 was completed and Final Test Plans were submitted to METC for three sites in 1988.

Task 3 progress for each of the test sites is summarized below:

2.1

Colorado

The test cell was constructed in June, 1989 with CFBC ash from a low sulfur western coal. The ash has low lime and sulfate content. Core samples were collected in June and December 1989, in March, June and December of 1990, and in June 1991. No groundwater or porewater samples have been recovered.

Cores strength is low to moderate ( 200 psi to $900 \mathrm{psi}$ ), with permeabilities of $2 \times 10^{-3}$ to $3 \times 10^{-4} \mathrm{~cm} / \mathrm{sec}$. Laboratory leachates show moderate concentrations of calcium, sulfate, and other common ions. Trace element concentrations in test leachates are low compared to regulatory limits. No leachate has been generated at the site.

\section{2}

Ohio

Two test cells were constructed, in February and April of 1989, using LIMB ash from an Ohio coal with $2.4 \%$ sulfur. The ash has a high lime and sulfate content. Test case 1 (north cell) was constructed with 25\% moisture; test case 2 was constructed with $38 \%$ moisture to optimize compaction. The wastes expanded, heaved, and fractured during the first year, particularly in the south cell. Mineralogical changes in the wastes with hydration and weathering are the primary cause. Core strength is low to moderate ( $<100$ psi to $2000 \mathrm{psi}$ ) and highly variable because of fracturing. Field measurements of permeability vary from $3 \times 10^{-3}$ to $5 \times 10^{-5} \mathrm{~cm} / \mathrm{sec}$. Permeabilities are lowest in the north cell. 
Large amounts of water were bound in the wastes in the first year as the waste saturated and hydrated. In the second year leachate migration from the south cell may have begun to impact the chemistry of one shallow downgradient well. The leachate contains up to several thousand $\mathrm{mg} / \mathrm{L}$ of sulfate, chloride, potassium, and sodium, with somewhat lower concentrations of calcium and silicon. Trace metal concentrations are generally low compared to regulatory limits, but a few samples show mobilization of metals.

Core samples were first collected in June, 1989, and quarterly and annual core sampling events have taken place according to schedule since that time. Water samples have been collected on a quarterly basis since October, 1989.

\section{$2.3 \quad$ Illinois}

The first Illinois test cell was completed in April, 1991, with BFBC ash from a Illinois coal with $3.1 \%$ sulfur. A large excess of limestone is used in the combustor; the ash is high in lime relative to most $\mathrm{FBC}$ wastes, containing up to $30 \% \mathrm{CaO}$. The ash also contains abundant sulfate, but has relatively low concentrations of typical coal ash constituents compared to other wastes included in this study. The two test cells planned for the second Illinois test case will evaluate the effects of added coal ash on cementitious reactions in the waste. Laboratory studies to define the optimum mix of FBC waste and coal fly ash are in progress.

The initial cell was instrumented and sampled in June 1991. Water samples and additional cores were collected in August and November, 1991. No expansion has been noted at the site. The wastes are solidified with unconfined compressive strength between approximately 150 and 550 psi, although some fracture zones may be present in the waste and may reduce overall strength. The permeability measured on cores recovered from the test cell ranges from $1 \times 10^{-6}$ to $2 \times 10^{-4} \mathrm{~cm} / \mathrm{sec}$; field permeability 
measurements range from a high of $3 \times 10^{-3}$ near the surface to a low of $2 \times 10^{-5}$ at depth in the test cell.

\subsection{OBJECTIVES FOR THE CURRENT REPORTING PERIOD}

The specific objectives for the reporting period of February, 1992 to April, 1992 were as follows:

- $\quad$ Make quarterly measurements at the Colorado site in March, 1992. Measure permeability and neutron absorption moisture content and collect on-site data from the data logger;

- Collect quarterly samples at the Ohio site in February, 1992. Measure permeability and moisture content, and collect water samples from the wells and lysimeters;

- $\quad$ Collect the quarterly core and water samples from the first Illinois test case in February, 1992. Make field measurements and collect data from the data logger;

- Analyze chemistry of all core and water samples collected;

- $\quad$ Continue preliminary laboratory testing for the second Illinois test case;

- Continue production of a video presentation on the project;

- $\quad$ Receive additional EERC data on the second annual cores from Colorado and Ohio and the first two sets of quarterly samples from Illinois and load all data into the project database; and

- Prepare Preliminary Assessment reports on the Ohio and Colorado sites for the DOE. 


\section{Colorado Ute Site}

Results of mineralogical analyses by x-ray diffraction for all Colorado ash samples collected to date are shown in Table 1; 1991 data has not been reported previously. Following the initial mineralogical changes as lime hydrated to portlandite and portlandite reacted with other ash constituents to form ettringite, only minor mineralogical changes have occurred. In the 1991 samples, gypsum is slightly more abundant than in 1990, averaging 6.6\% in 1991 and 3.2\% in 1990. 1991 samples with the highest gypsum content have the lowest anhydrite concentration, suggesting that hydration of the anhydrite is continuing slowly. Mullite and hematite are not reported for the 1991 samples, but are expected to persist in the test cell as they are essentially unreactive phases. Some deeper portions of the test cell appear to have remained very dry over the last two years; sample 91JUNCO1-17 (from a depth of 7.5 feet) still contains unreacted portlandite and has not hydrated to form any ettringite since the test cell was constructed.

The results of in situ permeability measurements at the Colorado test cell are shown in Table 2. Before December 1991, in situ permeability tests were made only on the top 2 feet of the wastes in the test cell; in 1991 the Guelph permeameter was modified to allow permeability testing of the entire thickness of the test cell. There does not appear to be any depth trend to the in situ permeability data for the Colorado test cell, although the 1991 permeability value for the near-surface wastes is lower than earlier measurements.

Updiated physical properties data for all samples collected from the Colorado test cell are shown ir Table 3. A few newly reported values for compressive strength and permeability of 1991 ann al cores are included here along with previously reported data. The new data appear consistent with earlier measurements. 
Quarterly water samples were collected from the Ohio site in February, 1992. Analytical results for these samples are presented in Table 4. The upgradient and downgradient groundwater compositions over the last two and three-quarters years are shown in Figures 1 through 3. In each Figure, separate graphs are shown, each providing data for groundwater from a different depth interval. Figures 1 through 3 illustrate the strong dependence of the groundwater chemistry at the Ohio site on the depth of sampling.

Major element concentrations in groundwater samples from the shallow well downgradient of the south cell (OHMW-06) appear to be leveling off or even decreasing following a generally increasing trend from approximately the eighteenth month after construction of the test cell. Since the concentrations of most major analytes in the porewater leachate, including sulfate and chloride, have declined o er time, and since the volume of leachate appears to have been reduced once the soil cover was constructed, the peak concentrations of the most mobile ash-derived contaminants may have already reached this well. Hydrological data and leachate production will be evaluated over the next few months to help confirm the chemical data.

The chemistry in the two deeper wells downgradient from the south cell is significantly different than that in the shallow wells. Most notably, in the wells completed 10 feet and 20 feet below the water table, the concentration of sodium is higher and the concentration of sulfate is lower than in the wells located at the water table. The overall trend of most constituents in the deeper wells are fairly constant, with one exception. Sulfate coucentrations in the deepest well (OHMW-04) dropped consistently over the first 22 months following cell construction, then leveled out at less then 100 $\mathrm{mg} / \mathrm{L}$. The deeper wells do not appear to show any effects from leachate derived from the test cells. The differences in chemistry between the shallow and deeper wells are probably due to natural causes. In particular, the elevated background sulfate 
OHMW-01

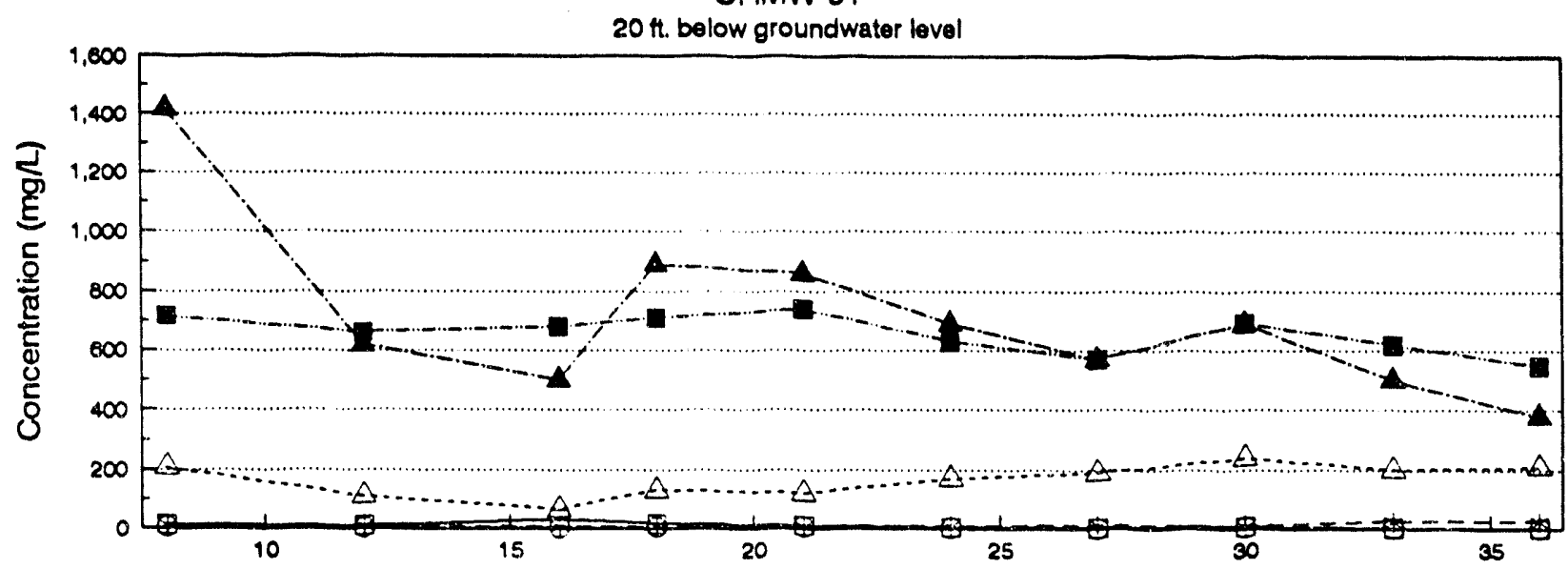

OHMW-02

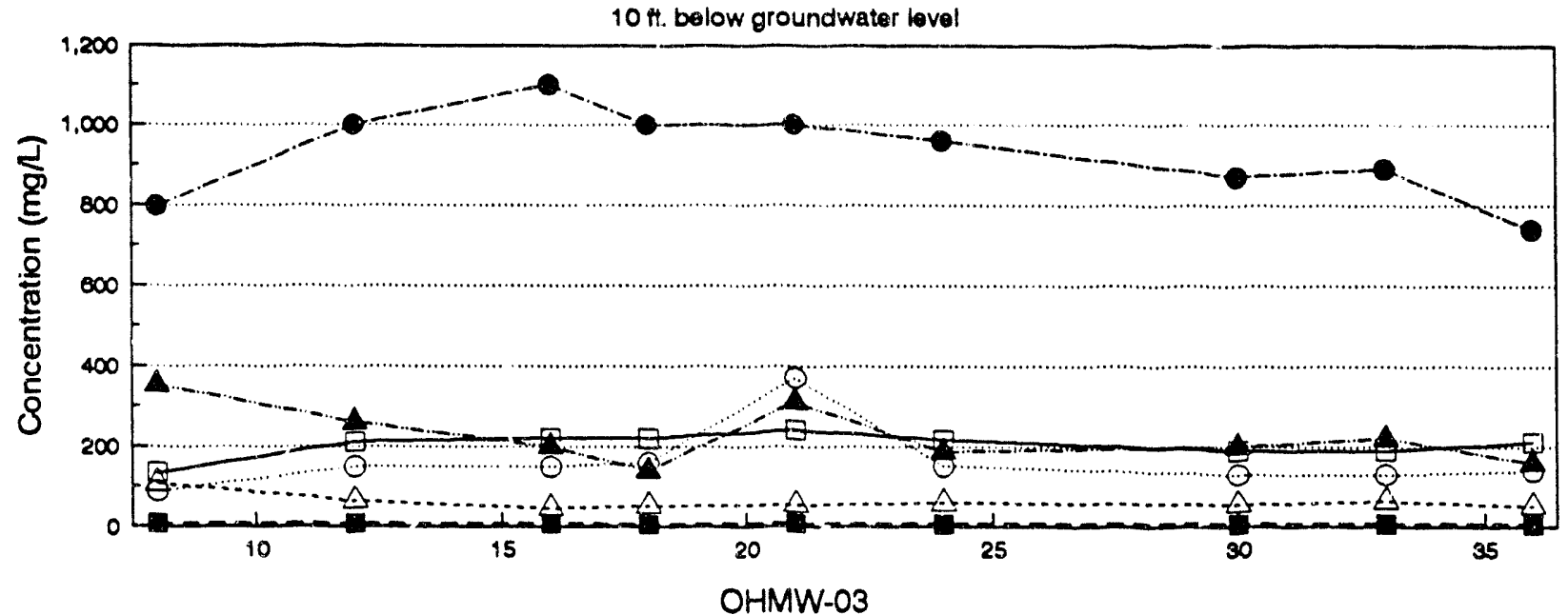

At grounchater lovel

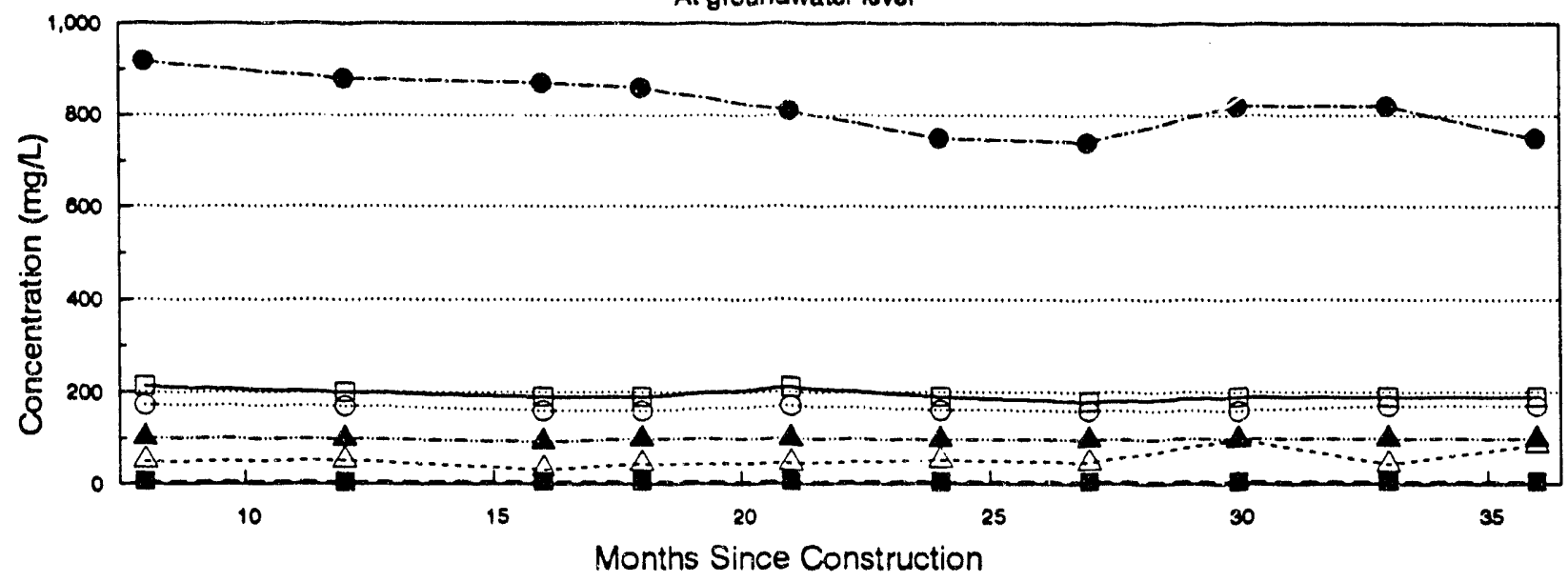

Calcium Chloride Magnesium Potassium Sadium Sulfate

Figure 1. Major Element Concentrations in Groundwater Samples from Wells Downgraident of the Ohio North Cell for All Sampling Events 
OHMW-04
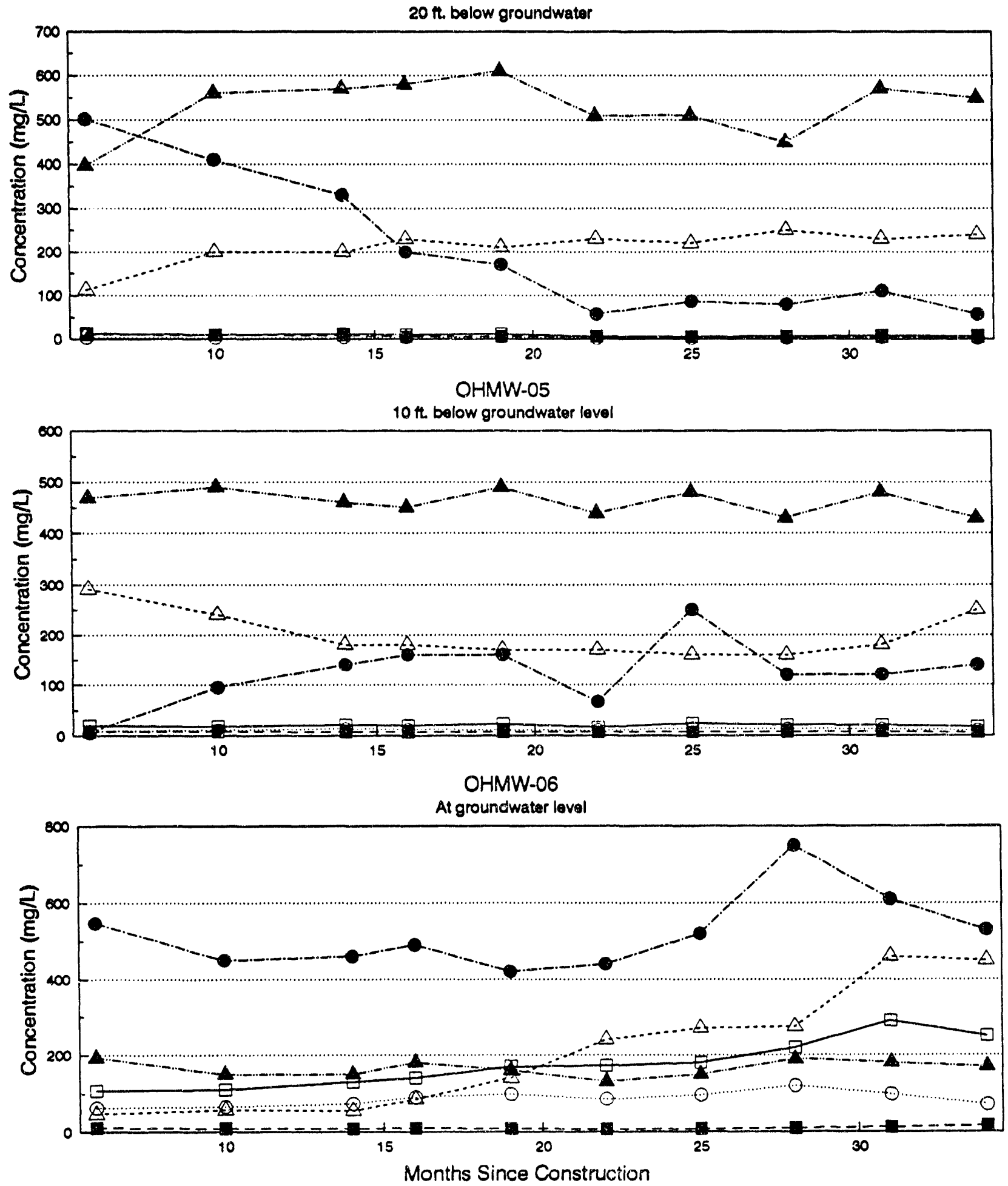

Calcium Chloride Magnesium Potasslum Sodium Sulfate

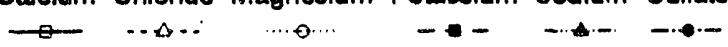

Figure 2. Major Element Concentrations in Groundwater Samples from Wells Downgradient of the Ohio South Cell for All Sampling Events 
OHMW-07

$15 \mathrm{ft}$. below groundwater level

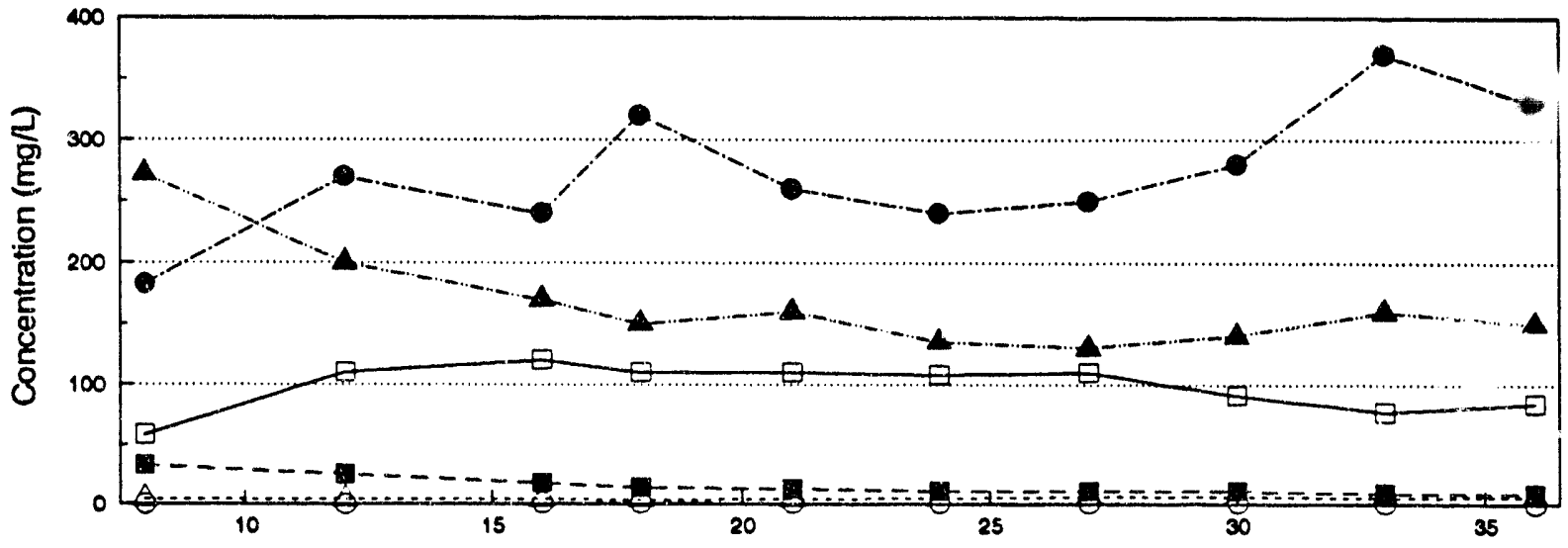

OHMW-08

At Groundwater Lovel

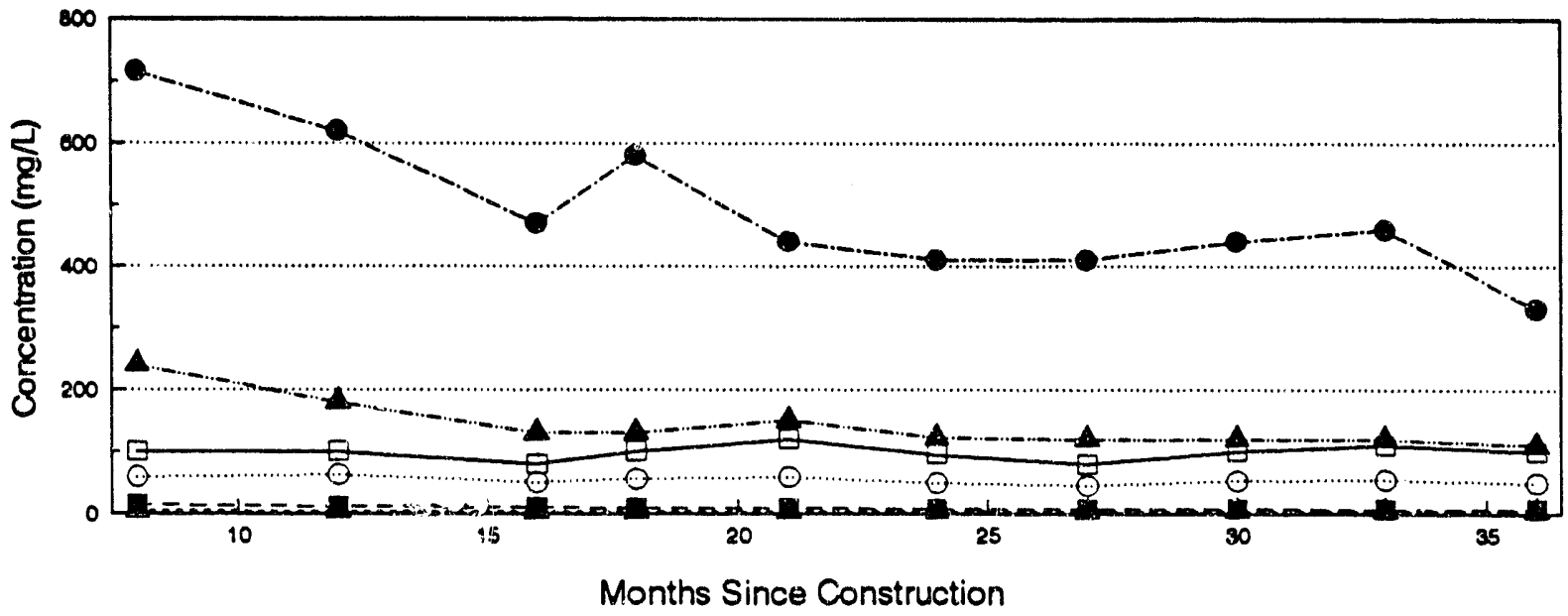

Calcium Chioride Magnesium Potassium Sodium Sulfato

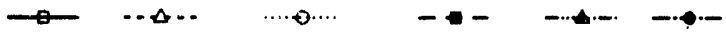

Figure 3. Major Element Concentrations in Groundwater Samples from Wells Upgradient of the Ohio Test Cells for All Sampling Events 
concentrations in the shallow wells may be related to pyrite oxidation in soils immediately above the water table. Pyrite oxidation in these soils was discussed in a previous report, in connection with strongly acidic pH's and elevated trace metal concentrations in leachates of several soil samples from beneath the test cells.

Although all of the wells downgradient from the initially dry north cell contain generally higher concentrations of dissolved solids than the south cell wells, no trends which can be attributed to leachate migration into the groundwater are apparent. The deepest of these wells (OHMW-01) contains an unusually high concentration of potassium, which is not found in significant amounts in any other well at the Ohio site. This well also contains high a level of sodium and little or no sulfate, similar to the deeper south cell wells.

Major element concentrations in some of the lysimeters from the south cell are shown in Figure 4. Although all lysimeters at tie site do not yield a sample every quarter, the overall trend has been towards decreasing corcentrations of major elements over time in both cells and at all depths. Tenth quarter lysimeter samples continue to follow this trend. The data indicate that these elements are being leached out of the test cell or incorporated into less soluble phases as time progresses.

The results of in situ permeability measurements at the Ohio test cell are shown in Table 5. In general, the lowest values correspond to greater depths. Also, most of the higher permeabilities occur at shallower depths during the month of August, which may be due to drying and cracking of the ash closer to the surface. All of the in situ permeability measurements are on the order of $10^{-4}$ or $10^{-5} \mathrm{~cm} / \mathrm{sec}$.

The updated physical properties data for the samples from the two Ohio test cells are shown in Table 6. Most of this data has been previously reported, but several new permeability measurements for the 1991 north cell core samples (91AUGOH6-.. and 91AUGOH8-..) are included here. These data show a wide range of 
OHLY-12, 1 foot below surface Concentration, $\mathrm{mg} / \mathrm{L}$

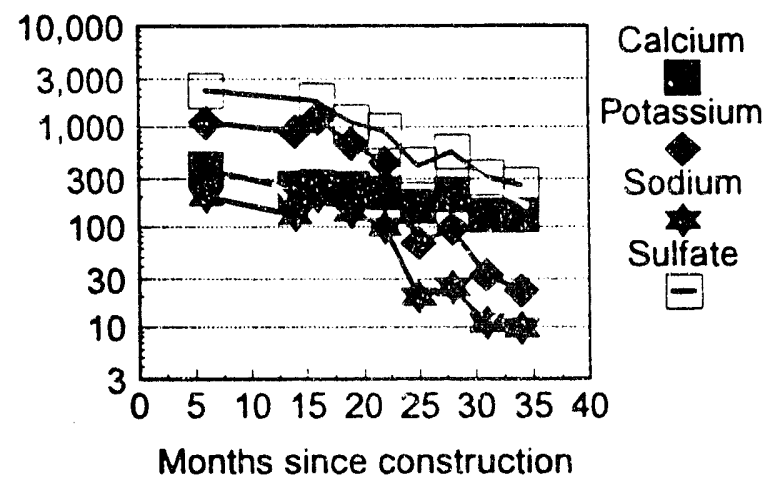

OHLY-10, 6.5 feet below surface Concentration, $\mathrm{mg} / \mathrm{L}$

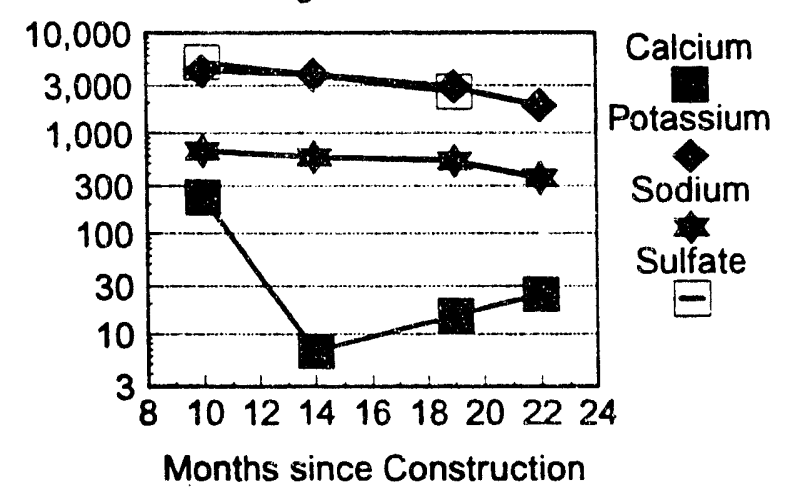

OHLY-11, 3 feet below surface Concentration, $\mathrm{mg} / \mathrm{L}$

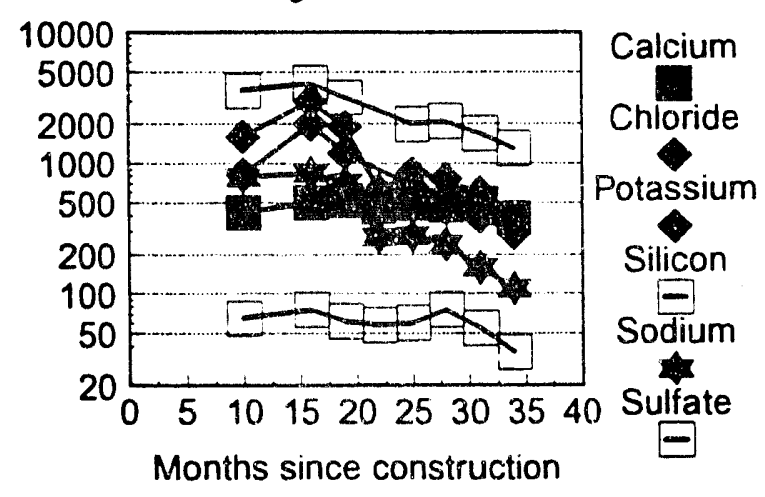

OHLY-16, 8.5 feet below surface Concentration, $\mathrm{mg} / \mathrm{L}$

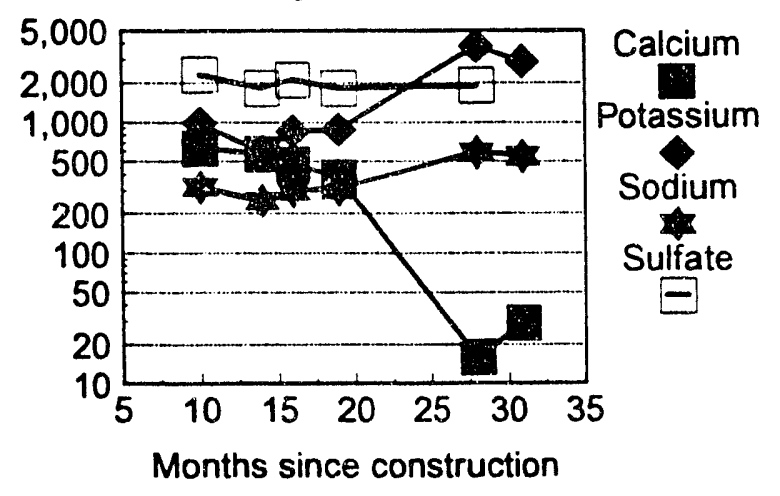

Figure 4. Major Element Concentrations in Porewater Samples from Lysimeters within the Ohio South Cell 
permeabilities in the core samples, from $8 \times 10^{-8}$ to $3 \times 10^{-3} \mathrm{~cm} / \mathrm{sec}$. Preliminary lab results for south cell permeabilities showed core permeabilities over $8 \times 10^{-3} \mathrm{~cm} / \mathrm{sec}$ in south cell cores. Closer examination of these samples showed that they contained small fractures which allowed rapid passage of water during the test; these results are not included in Tatle 6. The most permeable core samples from both of the Ohio test cells contain small fractures. It is not clear which samples were fractured in situ, and thus represent actual conditions in the test cell, and which were broken during the core sampling and recovery or sample preparation and are not representative of the actual field conditions. In general, the field permeability results should be used whenever possible, as these measurements do not necessitate the removal of material from the cell, thus avoiding possible core breakage during sampling and iransport. Also, in situ measurements integrate permeability over a larger area of the waste, and are less biased by the presence of small scale variations in the waste properties.

\section{3}

\section{Illinois Site}

The third set of quarterly water and core samples was collected in February, 1992 and analyzed in March. The analytical results for water samples are shown in Table 7, and those for ASTM leachates of the ash and soil samples are presented in Table 8.

Major element concentrations in groundwater samples from the Illinois site have generally decreased or stayed the same since sampling began. These trends are illustrated in Figure 5. With the exception of samples from the shallowest downgradient well (ILMW-03), calcium, magnesium and sodium levels in the groundwater have stayed essentially constant for all of the sampling events in both upgradient and downgradient wells. Analytical results for these elements in samples from ILMW-03 are variable. Sulfate and chloride concentrations generally decrease with time in the Illinois groundwater samples. Chloride values in samples from the first quarter are almost always significantly higher than in samples from the second and third quarters. There are no real 


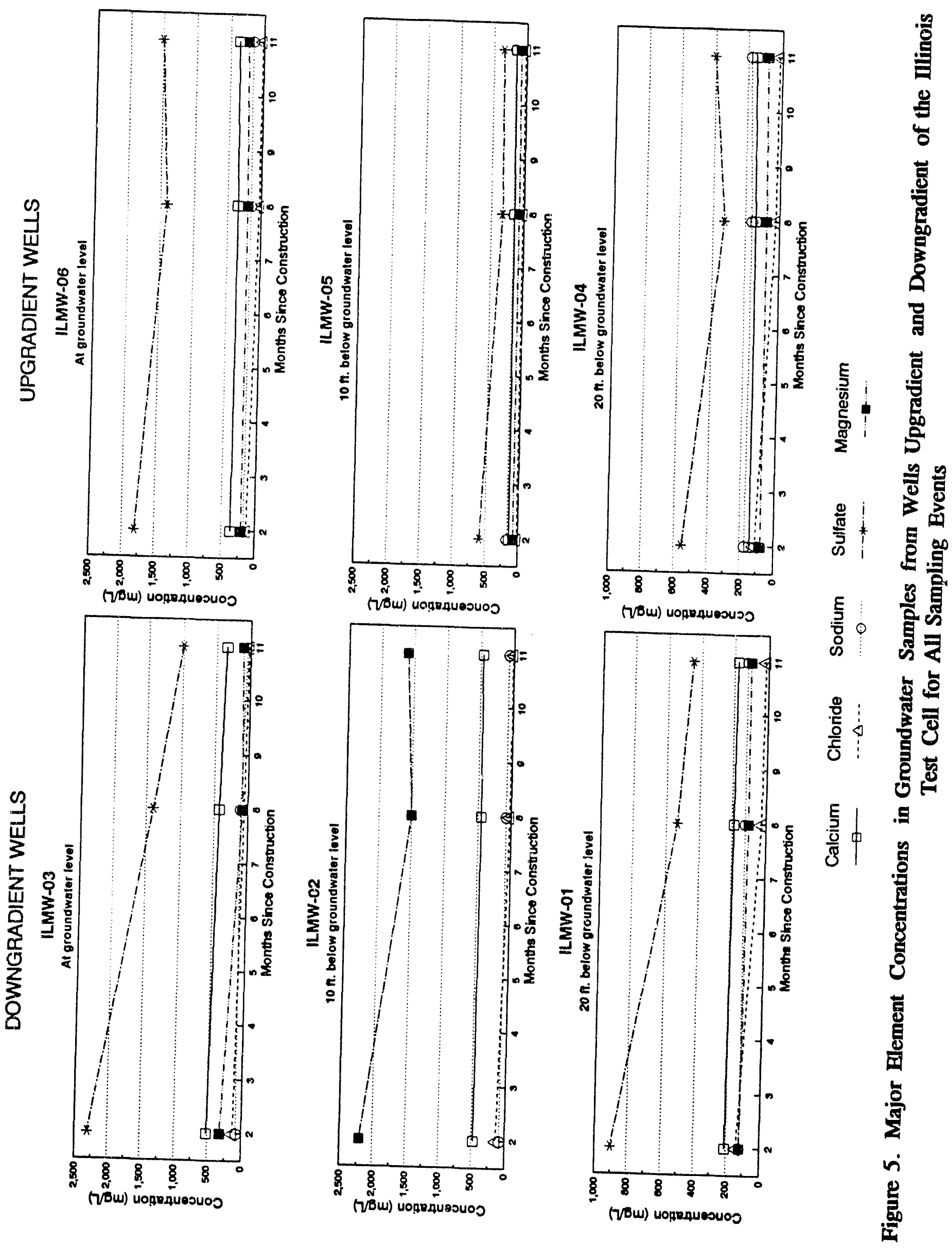


differences in the major element chemistry of the downgradient wells as compared to the upgradient wells. Data from upcoming sampling events will shed light on some of these observed trends. Trace element chemistry of the groundwater will be discussed in a future report.

Most of the lysimeters from the Illinois site have not been sampled more than once, so observations of changes with depth and time are not possible. Sulfate, potassium, sodium, and chloride make up the major dissolved components in the porewater at this site.

The quarterly cor: samples have provided a more consistent record than the lysimeters in the first year of sampling at the Illinois site. Changes in solubility of some of the major elements in the ash are appa:ent when comparing the composition of ASTM leachates from the initial ash and cores collected during the three sampling events. These changes are shown in Figure 6.

Sodium and potassium are both found in generally higher concentrations in the leachates from the core than from the initial ash, indicating that these two elements are becoming more soluble as a result of reactions within the test cell. However, concentrations of sodium and potassium in leachates from the shallowest samples may actually be lower than those from the initial ash, possibly indicating that these elements are being leached from these samples deeper into the cell. The observation that the highest leachate concentrations of sodiurn and potassium occur at increasingly greater depths with time may indicate that these elements are gradually leaching through the test cell. Chloride concentrations in core leachates are also lower than those from the initial ash, possibly indicating leaching from the uppermost foot of the test cell. The depletion of soluble constituents from the upper portions of the test cell is consistent with the pattern of leaching observed in the Ohio test cells. Since no new phases incorporating sodium, potassium, or chloride have been observed, the lower concentrations of these species in 


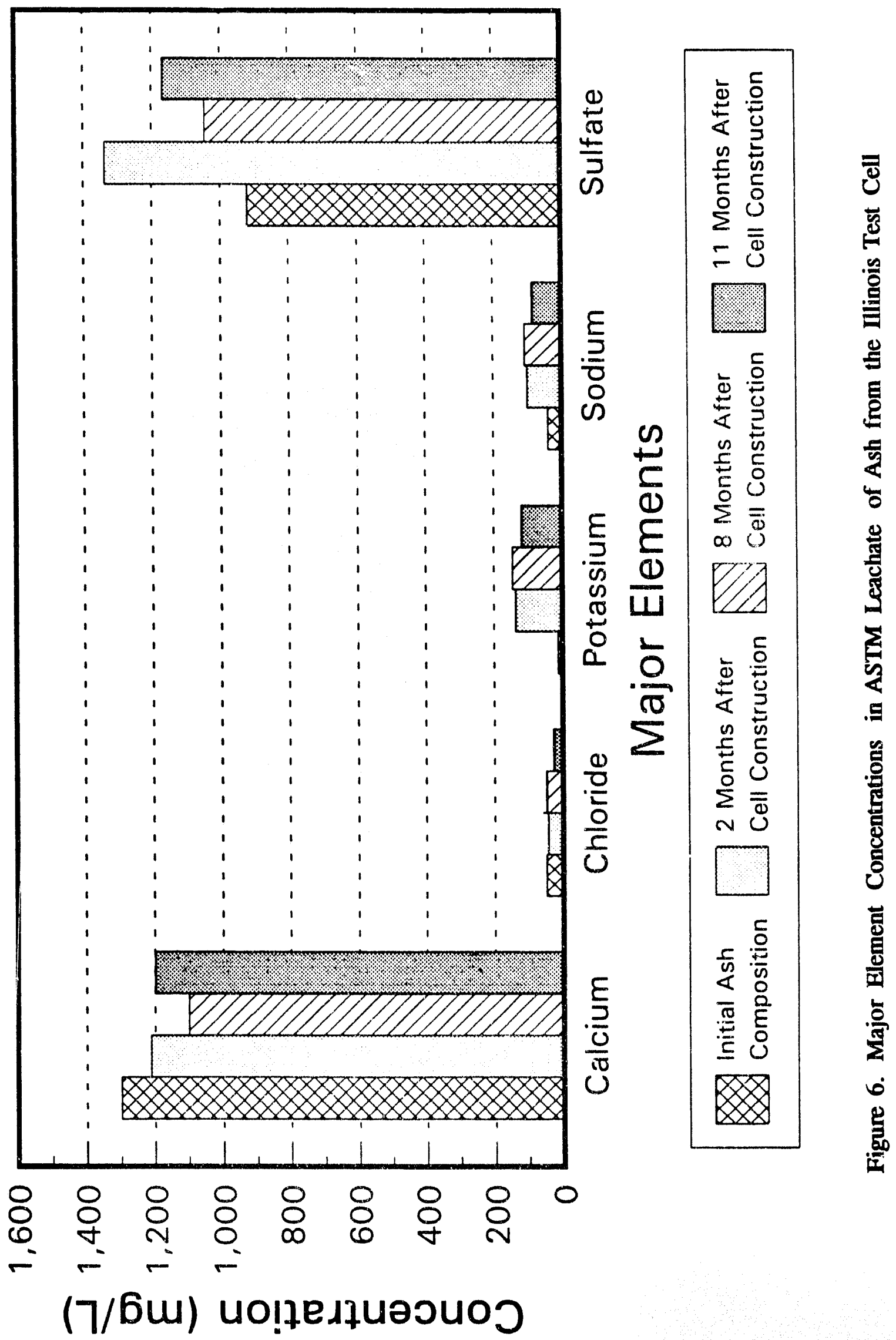


leachates from the core samples does not appear to be a result of incorporation of these constituents into some low solubility phase.

Calcium and sulfate levels in the ASTM leachates from the core do not exhibit significant changes with time or depth. However, sulfate values in leachates from the core are generally higher than those from the initial ash, indicating that some solubilization of sulfate may have occurred inimediately following placement of the ash in the test cell. In contrast, in both the Ohio and Colorado test cases, a sharp decrease in the leachable calcium concentration was observed after the wastes were placed in the landfill. The higher initial lime content of the Illinois ash is probably responsible for this difference.

The results of mineralogical analysis by XRD for the initial (ILASH) and first quarterly (91JUNIL) Illinois samples are shown in Table 9. Portions of this data were reported earlier, as Appendix A to the November, 1991 through January, 1992 Quarterly Technical Progress Report. The primary mineralogical features of the landfilled FBC waste are the formation of $20 \%$ to $30 \%$ ettringite in the landfilled material, and the persistence of $10 \%$ to $20 \%$ calcium hydroxide, or portlandite, in the waste three months after landfill construction was completed. In both the Colorado and Ohio test cases, all the initial lime was quickly consumed in pozzolanic reactions. The Illinois FBC waste has a higher initial lime content, and may continue to react for a longer period of time.

Table 10 shows the results of in situ permeability tests at the Illinois site. Tests in June and August, 1991 measured permeabilities between approximately $1 \times 10^{-3}$ and $3 \times 10^{-3} \mathrm{~cm} / \mathrm{sec}$; tests in November, 1991 and February, 1992 measured substantially lower permeabilities, between $6 \times 10^{-4}$ and $6 \times 10^{-5} \mathrm{~cm} / \mathrm{sec}$. The February, 1992 results also show a trend from higher permeability near the surface $\left(6.5 \times 10^{-4} \mathrm{~cm} / \mathrm{sec}\right.$ at $\left.0^{\prime}-0.5^{\prime}\right)$ to lower permeability at depth $\left(9.8 \times 10^{-5} \mathrm{~cm} / \mathrm{sec}\right.$ at $\left.6^{\prime}-8^{\prime}\right)$. These results are shown in Figure 7. 


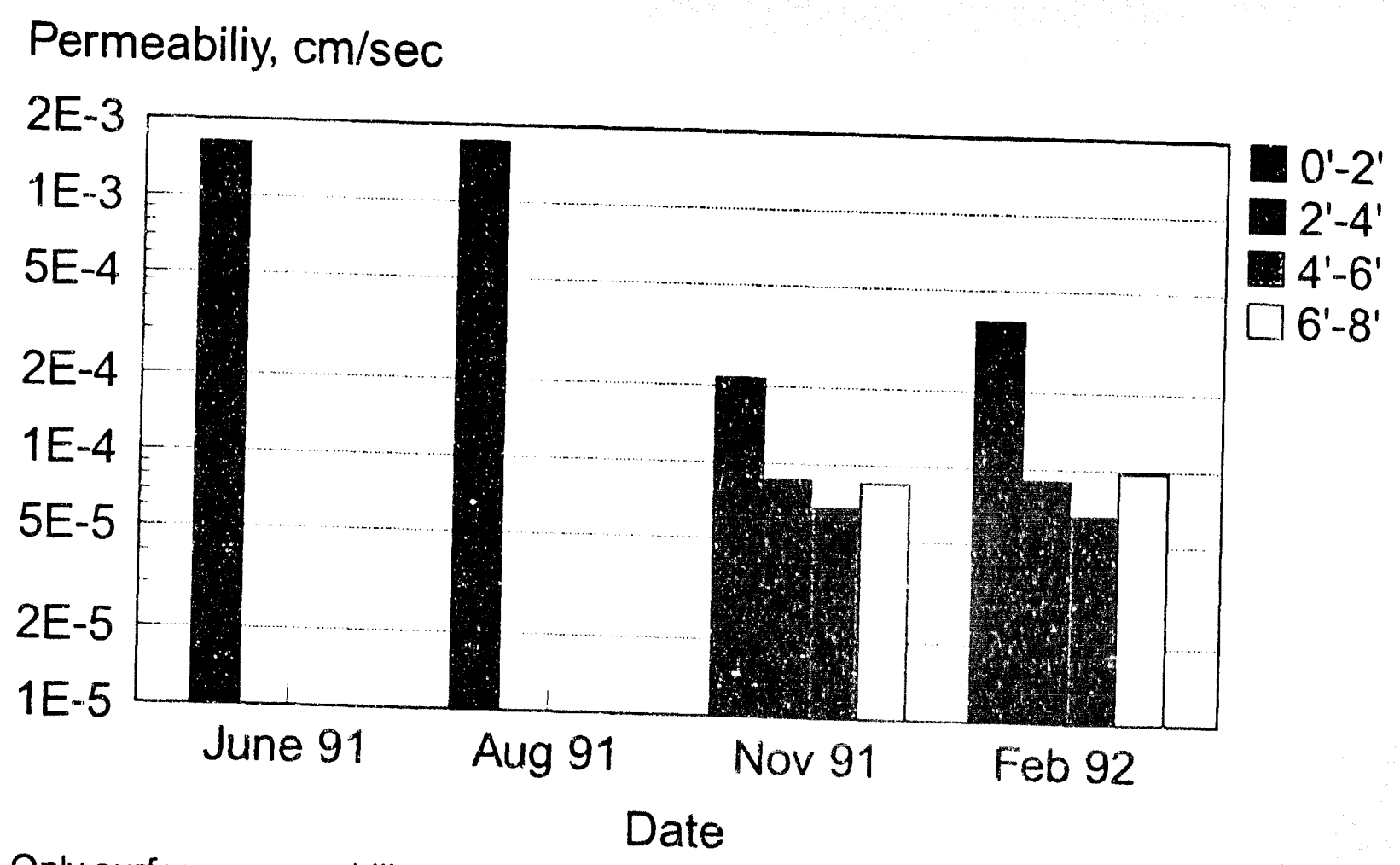

Only surface permeability was measured in Jurie and November, 1991. Where several results are available for a given depth, averages are shown

Figure 7. Illinois Test Cell In-Situ Permeability Measurements 
The results of physical properties tests on Illinois core samples are shown in Table 11. Most of the data shown in Table 11, with the exception of the November, 1991 core data, were presented in the previous Quarterly Report. The wastes in the test cell have an average moisture content of $37 \%$, significantly higher than the surrounding soils, indicating that generally adequate water is available for hydration reactions, although a few pockets of the landfilled waste continue to be extremely dry, as seen in sample 91JUNIL3-5,6. The unconfined compressive strength of the ash core samples is fairiy uniform, ranging from approximately 140 psi to 575 psi, suggesting that dry areas are localized. The average strength of the June cores (356 psi), is nearly the same as for the November cores (332 psi). Core permeabilities in June average $1.8 \times 10^{-5} \mathrm{~cm} / \mathrm{sec}$, and $5.8 \times 10^{-5} \mathrm{~cm} / \mathrm{sec}$ in November; the core permeabilities do not reflect the drop in permeability noted in the field permeameter results.

Initial laboratory testing of mixtures of the Midwest Grain FBC waste and fly ash continues. Initial test results for strength and permeability testing are shown in Table 11. Midwest Grains FBC waste compacted at optimum moisture did not gain strength during 28 days curing in moist conditions, while a 50:50 mixture of the Midwest Grain FBC waste and fly ash from an Illinois \#6 coal gained strength progressively during the curing period and had a 28 day strength approximately 10 times greater than the FBC waste alone, as shown in Figure 8. Figure 9 shows the relationships between the percentage fly ash addition and changes in strength and permeability for mixtures prepared at optimum moisture content. Strength at 28 days increased in a nearly linear fashion as the arnount of fly ash increased, while the permeability initially increased with fly ash addition, then dropped by more than a factor of 10 for a 50:50 mixture.

The results of thermogravimetric analysis (TGA) on samples of several FBC/fly ash mixtures are shown in Figures 10 through 12 . These analyses show that, after 28 days moist curing, a large fraction of the initial calcium hydroxide remains unreacted in each of the mixtures. Sample FA0 (no added fly ash) has $52.1 \%$ calcium hydroxide, FA25 (25\% added fly ash) has $35.6 \%$ calcium hydroxide, and FA50 (50\% 
$0 \%$ Added Fly Ash

Unconfined Compressive Strength, psi

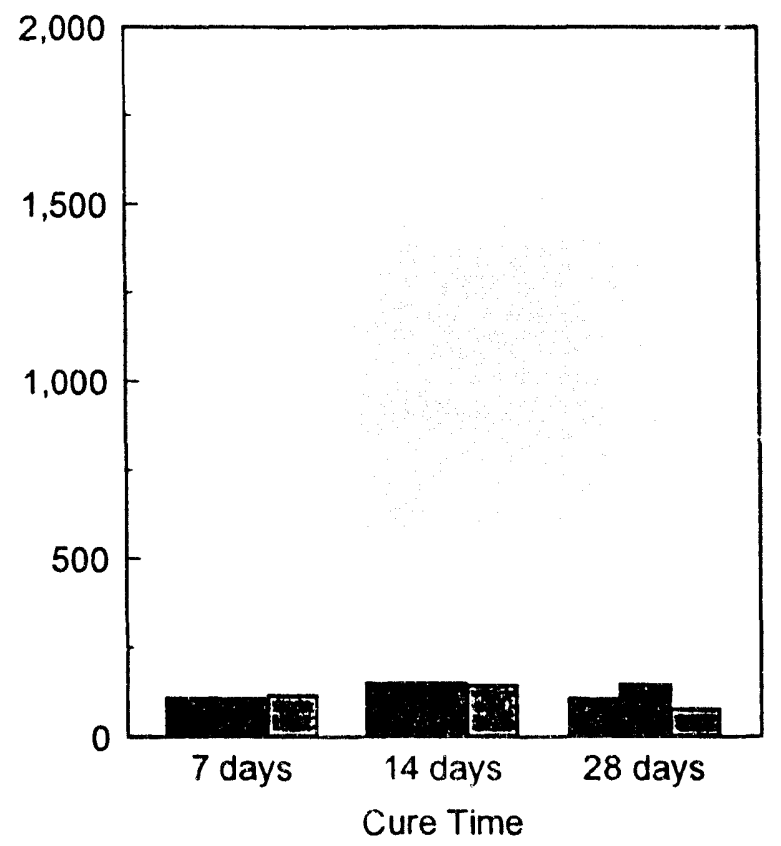

$50 \%$ Added Fly Ash

Unconfined Compressive Strength, psi

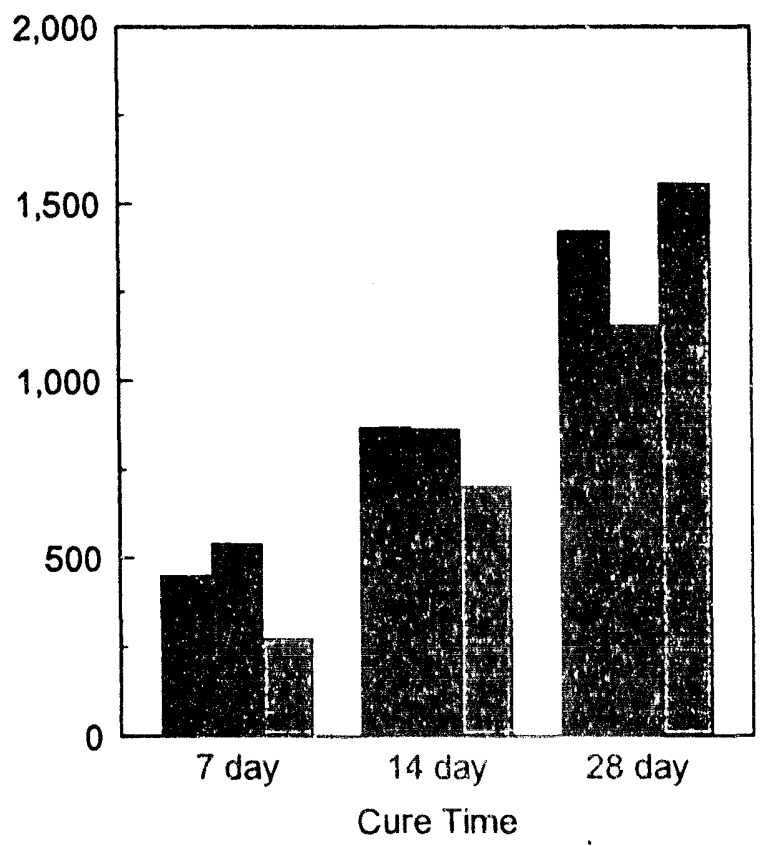

Figure 8. Effects of Fly Ash Addition to Midwest Grains FBC Waste (Fly Ash from Illinois \#6 Coal was Used) 

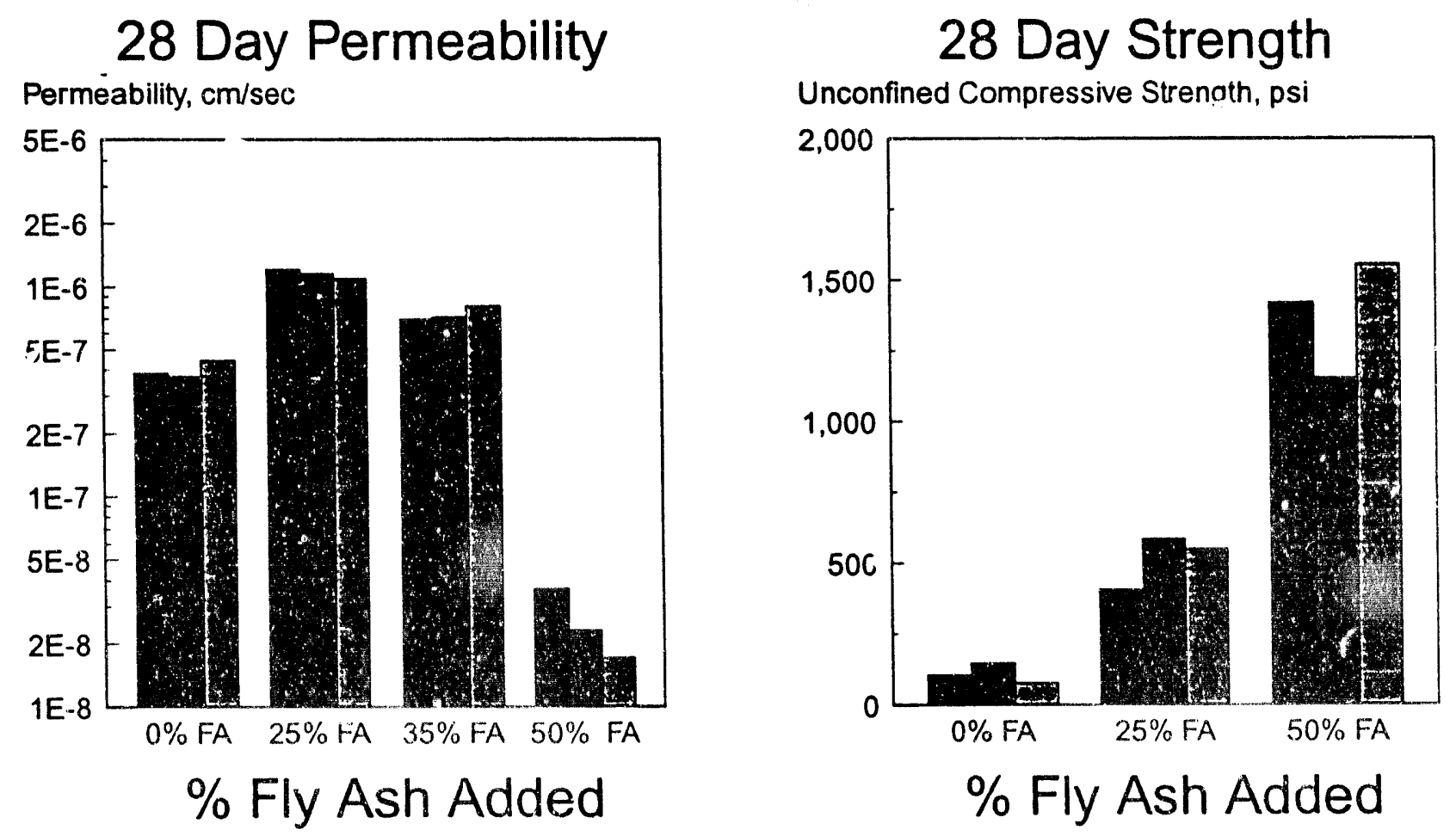

Figure 9. Strength and Permeability of Midwest Grain BFBC Waste/Fly Ash Mixtures After 28 Days Moist Curing 


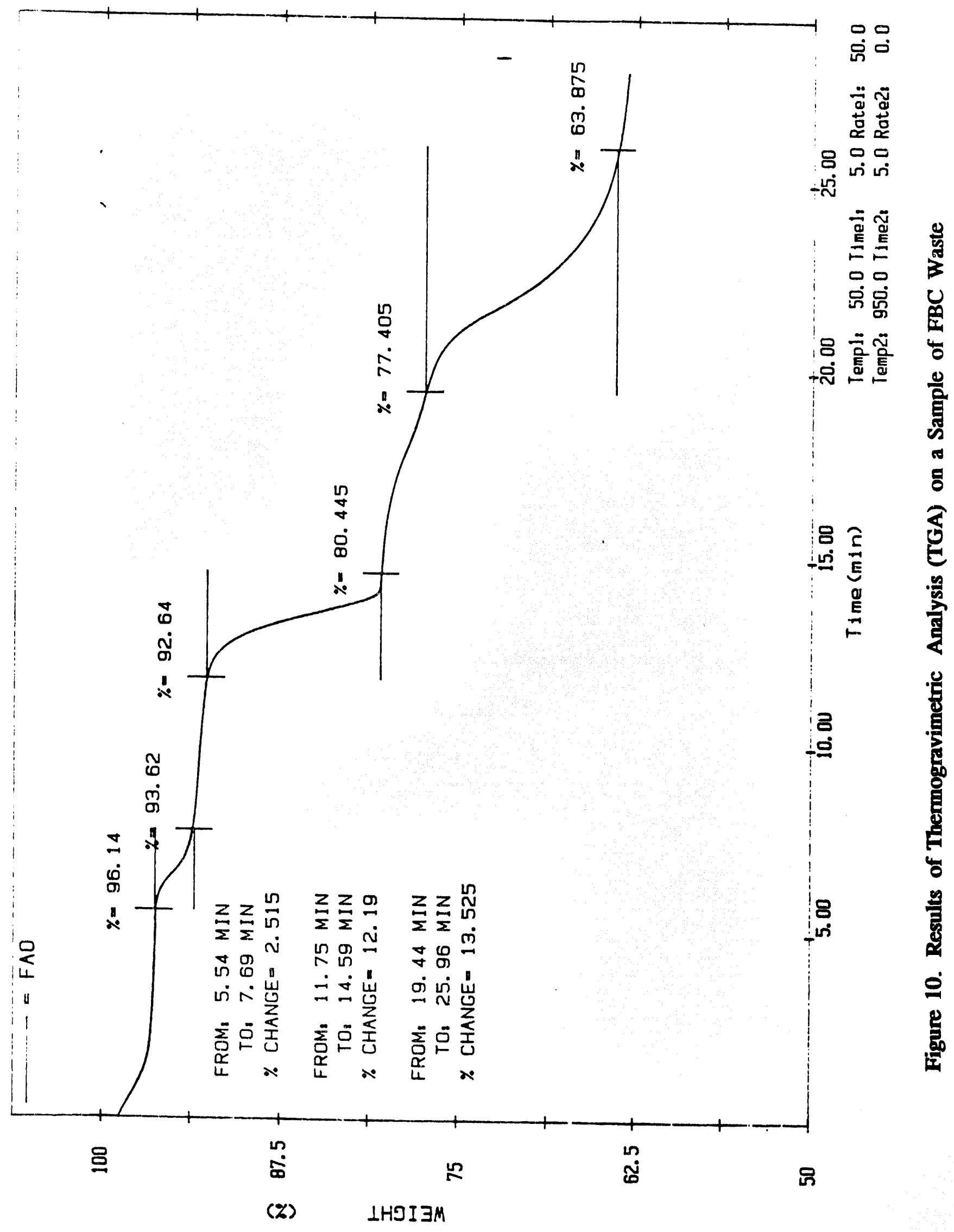




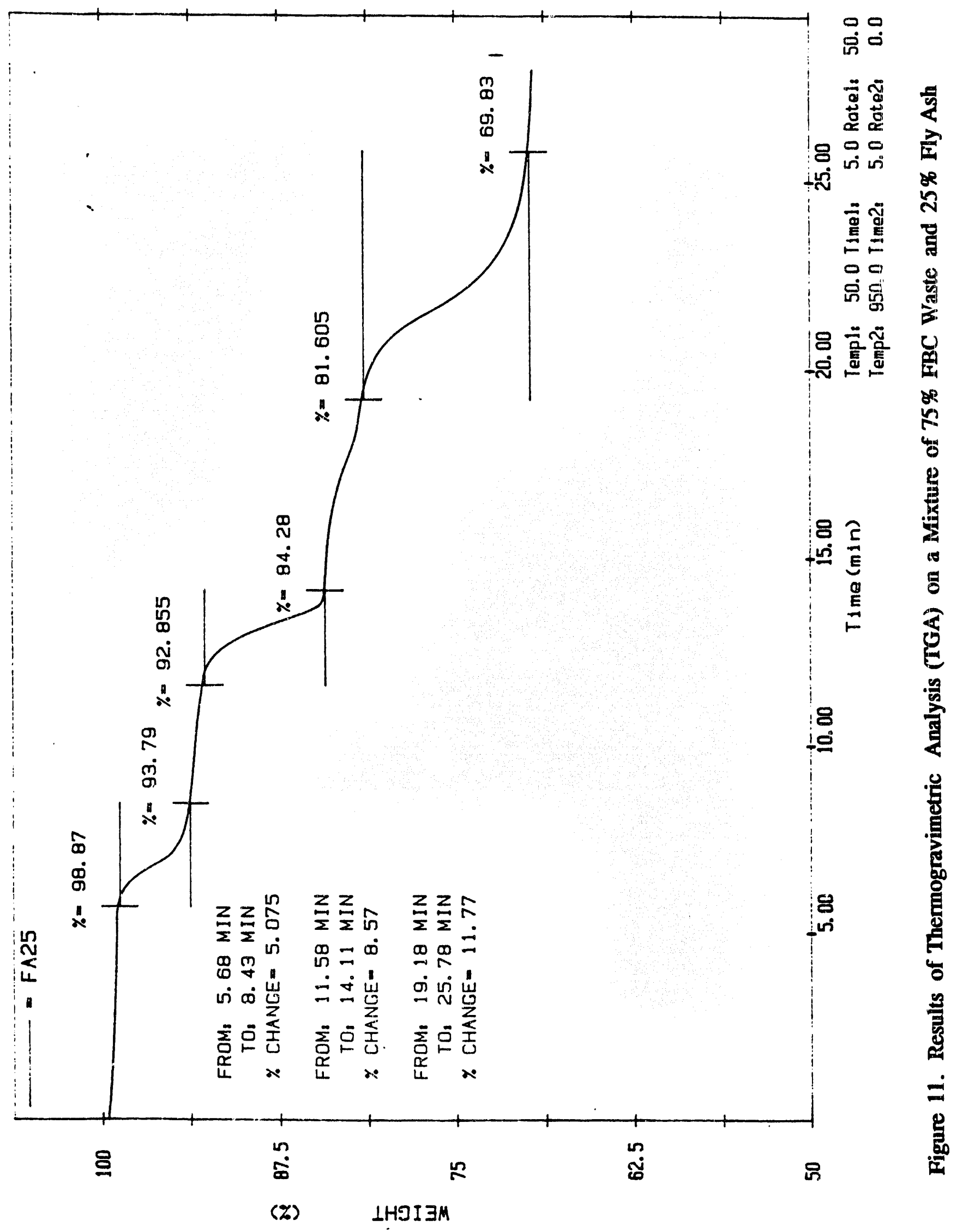




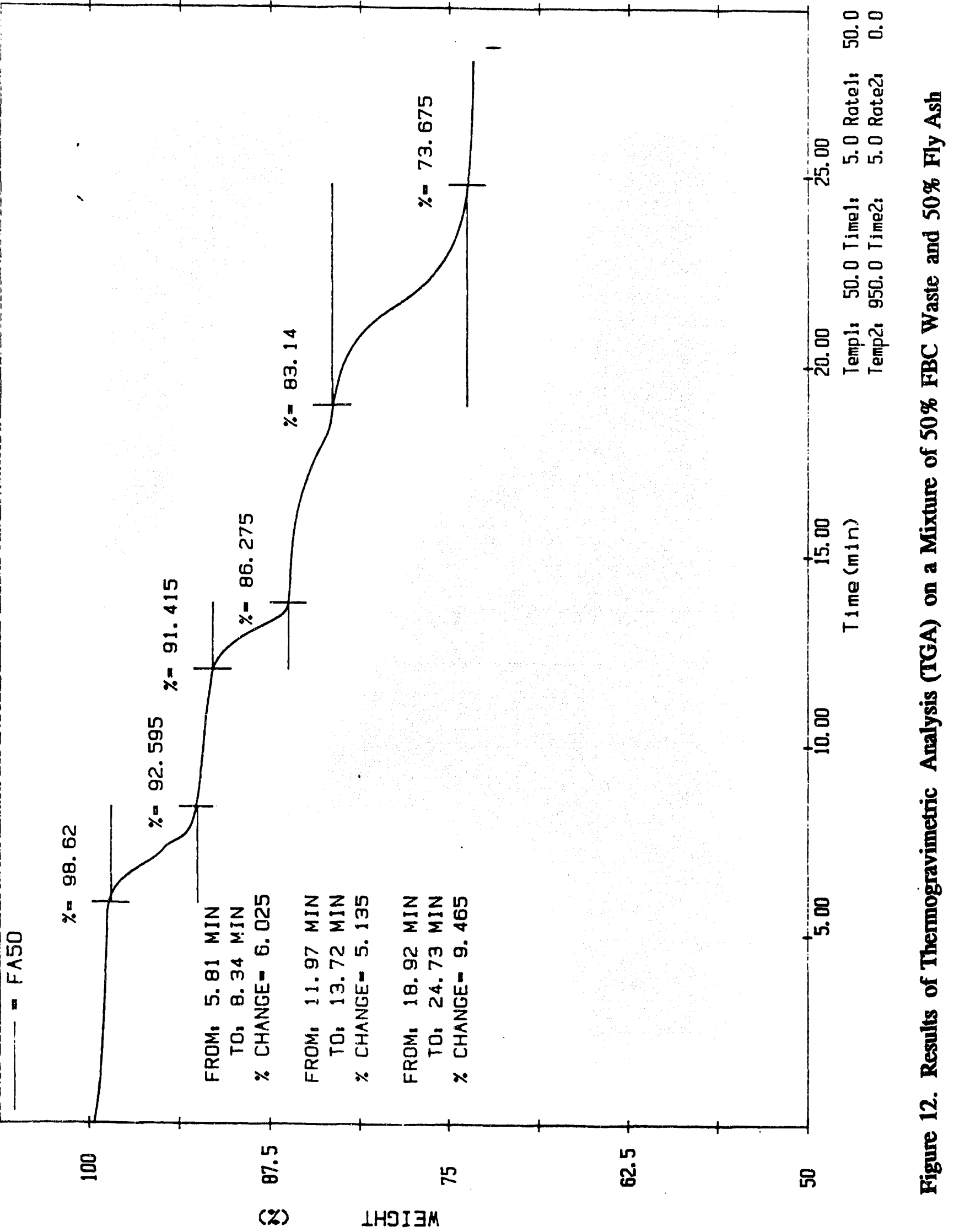


added fly ash) has $21.4 \%$ calcium hydroxide, based on the weight loss measurements between 11 and 14 minutes of the heating cycle (350 to 500 degrees Celsius). The amount of calcium hydroxide in the mixtures decreases during curing. Mixtures with more fly ash lose more calcium hydroxide, suggesting that pozzolanic reactions to form ettringite are more extensive when fly ash is present, consistent with the strength data. However, the TGA results show that most of the lime, even in a 50:50 mix, is not used up during the initial 28 days of curing. Presumably, this lime will continue to react over time and should progressively increase the strength of the mixtures with longer curing times. More detailed analysis of the TGA data will follow after $\mathrm{x}$-ray diffraction analyses of these samples are completed and mineral abundances for all the major phases can be calculated.

Figure 13 shows the effects of increased initial moisture content on the strength development of 50:50 FBC/fly ash mixtures. Mixtures with 3\% more water than the previously determined optimum moisture content had a slightly increased strength, while the wetter mixtures show a progressive decline in unconfined compressive strength after 14 days curing. Mixtures with $12 \%$ and $15 \%$ water over OMC were pumpable slurries which did not require compaction, and which set without release of any free liquids to give 14 day strengths of approximately 300 psi. Preliminary tests suggest that these high-moisture samples may achieve considerably higher strengths ( $>1500 \mathrm{psi}$ ) after longer curing times. The 28 day strengths and permeabilities of all of these mixtures will be tested as soon as the cure period is finished.

The densities of the cured mixtures, shown in Figure 14, generally correlate positively with strength, except for the mixture at $3 \%$ over OMC. Bulk (field moist) density ranges from 1.76 to $1.9 \mathrm{~g} / \mathrm{cm}^{3}$, and dry density ranges from 1.46 to $1.66 \mathrm{~g} / \mathrm{cm}^{3}$. Samples with a lower density generally have lower strength, although samples prepared with an initial water content $3 \%$ over OMC had the highest strength even though their density was lower than samples with more or less initial water. 


\section{Unconfined Compressive Strength, psi}

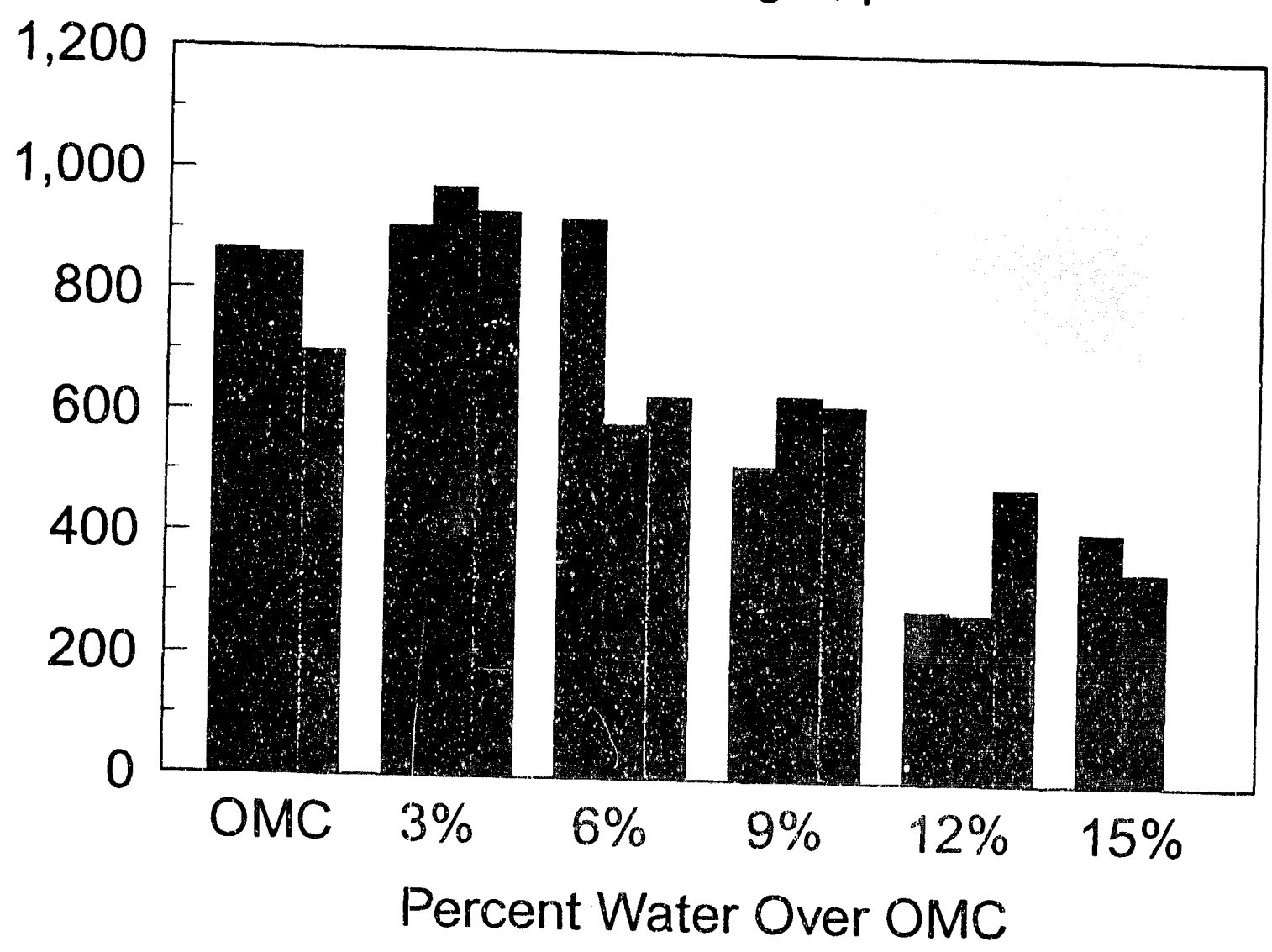

Figure 13. Effects of Increased Initial Water on 14 Day Strength of FBC/Fly Ash Mixtures 
Bulk Density of FBC/Fly Ash Mixes Density, g/cc

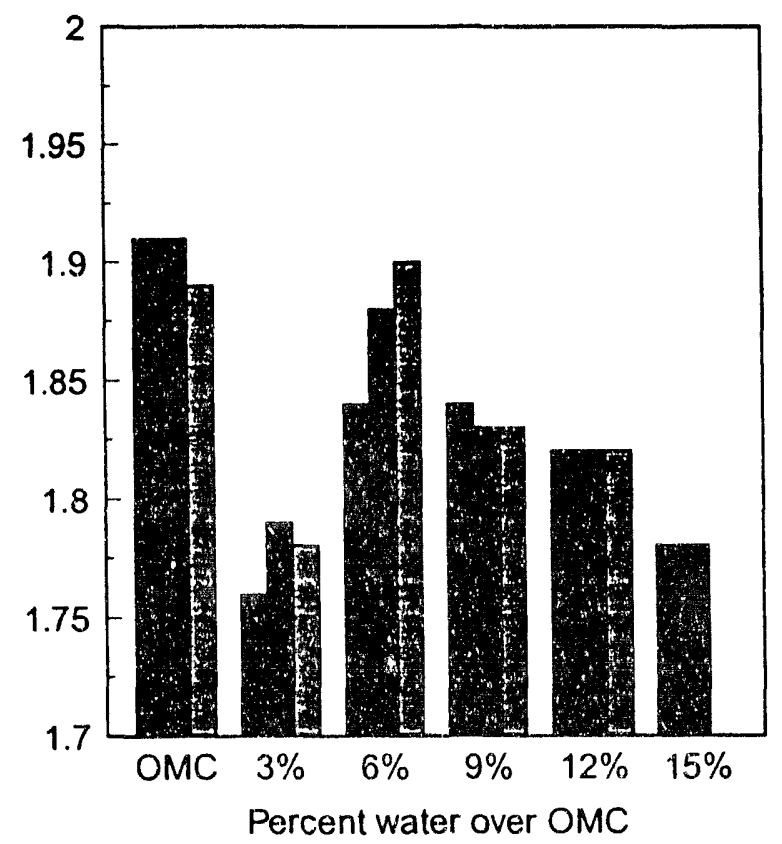

Dry Density of FBC/Fly Ash Mixes Dry density, g/cc

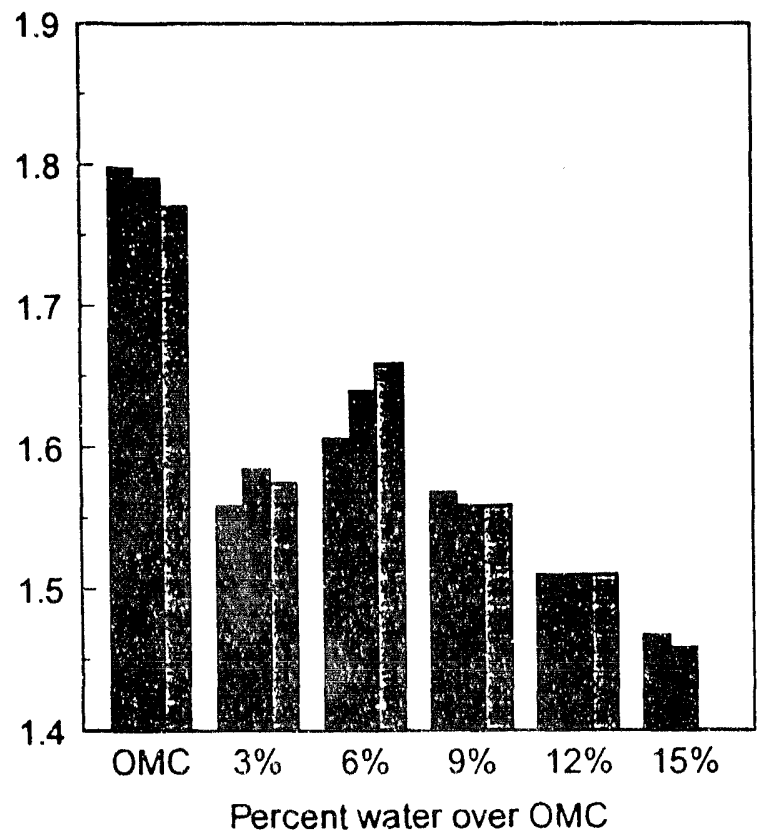

Figure 14. Bulk Density and Dry Density of Prepared Samples of FBC/Fly Ash Mixtures 
No expansion was observed in any of the test specimens of FBC/fly ash mixtures prepared for this program. The only volumetric change noted was a slight shrinkage of the wettest mixtures before setting. Several cylinders were prepared earlier using soluble sources of aluminum (either $\mathrm{Al}(\mathrm{OH})_{3}$ sludge or aluminum sulfate solution) in addition to fly ash to promote rapid ettringite formation and speed initial set. These mixtures did harden somewhat faster, but expanded significantly as they set and still more when exposed to external sources of water, producing extensive fractures in the samples. Testing of these mixtures was discontinued.

Complete data tables for the Colorado and Ohio sites were not included in the Preliminary Assessment reports as planned. Discussion with the Radian Data Management team led to the conclusion that electronic data transfer would be both more efficient and more useful to any potential users. The best format for data transfer will be discussed with METC.

The following activities are planned for the period of May 1992 through July 1992:

- The final or 3 rd annual sampling at the Colorado site is scheduled for June, 1992. Permeability and in situ moisture content measurements will be made and on-site data collected from the data logger;

- Quarterly sampling at the Ohio site is scheduled for May 1992. Permeability and moisture content measurements will be made, and water samples collected;

- Chemical analysis of samples will continue; 
- The first annual core samples and the fourth quarterly water samples from the first Illinois test case will be collected in May; other field measurements will also be made at that time;

- Preliminary testing of waste mixtures for the second Illinois test case will be completed;

- Radian will continue production of a short video presentation on the advanced coal wastes test program;

- $\quad$ EERC data will continue to be loaded onto the project database and reported as available. Complete results for the Colorado and Ohio sites will be provided in electronic form as soon as the format is agreed upon, and

- $\quad$ Preliminary Case Reports on the Colorado and Ohio test cases will be delivered to METC during April. The reports will cover results from the first two and one half years of testing, and include recommendations on tine scope and costs of continued testing. 


\section{Table 1}

\section{Field Testing - Solid Waste Disposal X-Ray Diffraction Mineralogy - Ash}

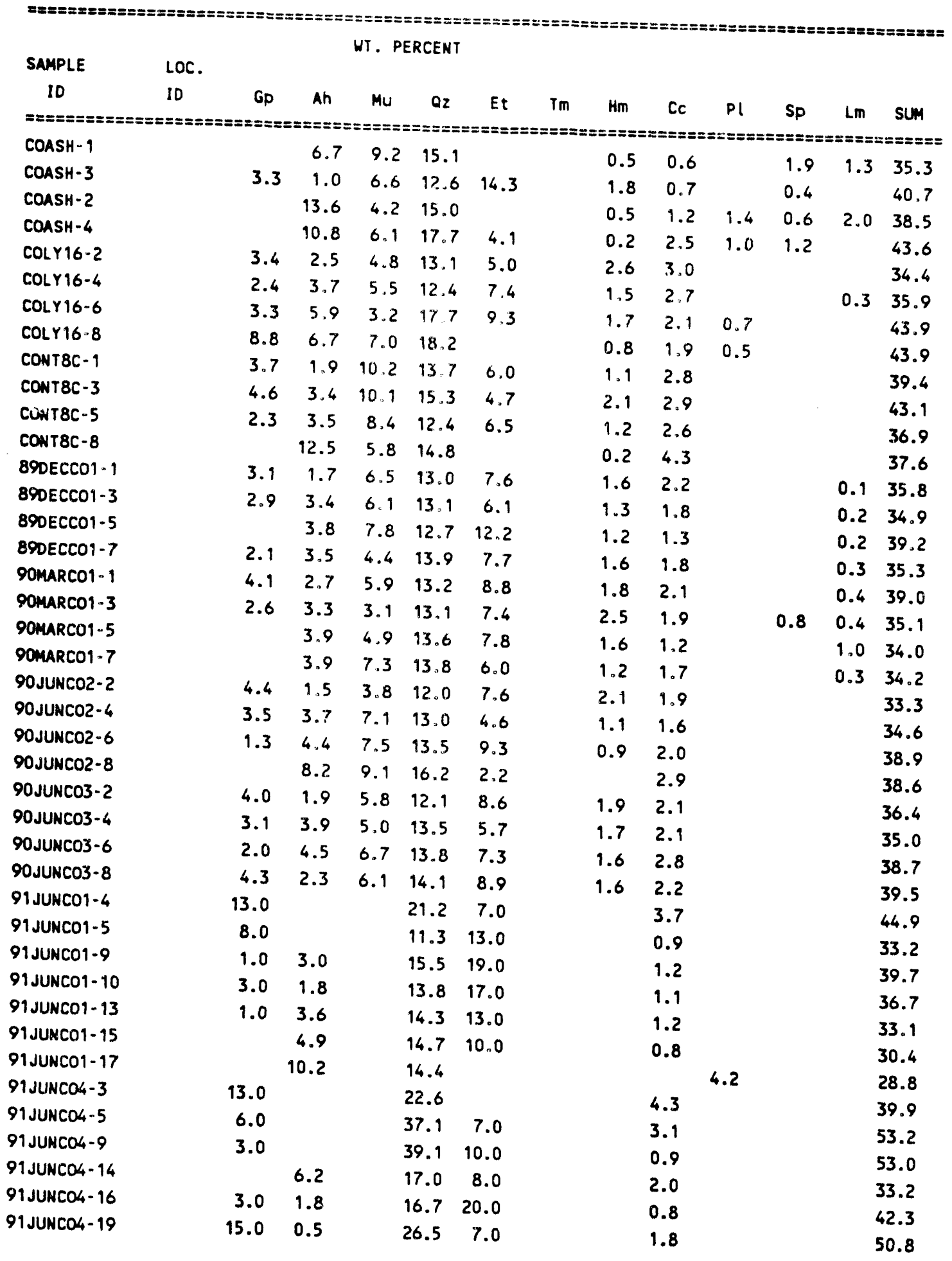


Table 1

(Continued)

\begin{tabular}{|c|c|c|}
\hline Anhydrite & Ah & $\mathrm{CaSO} 4$ \\
\hline Calcite & Cc & $\mathrm{CaCO3}$ \\
\hline Ettringite & Et & $\mathrm{Ca} 6 \mathrm{Al} / 2(\mathrm{SO} 4) 3(\mathrm{OH}) 12.26 \mathrm{H} 2 \mathrm{O}$ \\
\hline Thaumasite & $\operatorname{Tm}$ & Ca6Si2 [( $\left.\left.\mathrm{SO}_{4}\right) 2(\mathrm{CO} 3) 2\right](\mathrm{OH}) 12.26 \mathrm{H} 2 \mathrm{O}$ \\
\hline Fe-Spinel & Sp & $\mathrm{Fe} 304$ \\
\hline Gyosum & Gp & $\mathrm{CaSO}_{4} .2 \mathrm{H} 2 \mathrm{O}$ \\
\hline Hematite & $\mathrm{Hm}$ & $\mathrm{Fe} 203$ \\
\hline Lime & $\operatorname{Lm}$ & $\mathrm{CaO}$ \\
\hline Mullite & Mu & A16Si2013 \\
\hline Portlandite & Pl & $\mathrm{Ca}(\mathrm{OH}) 2$ \\
\hline Quartz & 02 & sio2 \\
\hline
\end{tabular}




\section{Table 2}

Field Testing - Solid Waste Disposal In-Situ Hydraulic Conductivity Data

\begin{tabular}{|c|c|c|c|c|c|c|}
\hline Date & Test \# & $\begin{array}{c}\text { Location } \\
\text { Quad }\end{array}$ & $\begin{array}{c}\text { Interval } \\
\text { Tested } \\
\text { (ft-ref) } \\
\end{array}$ & $\begin{array}{c}\mathrm{Kfs} \\
(\mathrm{cm} / \mathrm{sec}\end{array}$ & $\begin{array}{c}\mathrm{Kfs} \\
(\mathrm{ft} / \mathrm{yr}) \\
\end{array}$ & Comments \\
\hline $06 / 23 / 90$ & COBP-1 & S.E. & $.37-1.5$ TOA & $8.95 \mathrm{E}-04$ & 926 & \\
\hline $06 / 23 / 90$ & CO-BP1a & S.E. & $.12-1.5$, TOA & $6.761 \mathrm{E}-04$ & 694 & \\
\hline $06 / 23 / 90$ & CO-BP2 & N.W. & $.45-1.3^{\prime}$ TOA & $9.70 \mathrm{E}-04$ & 1000 & \\
\hline $06 / 23 / 90$ & CO-BP2a & N.W. & $.7-1.3^{\prime} \mathrm{TOA}$ & 7.33E-04 & 758 & \\
\hline $06 / 23 / 90$ & CO-BP3a & N.E. & 44-1.2' TOA & $1.41 \mathrm{E}-03$ & 1460 & \\
\hline $12 / 14 / 90$ & $\mathrm{CO}-\mathrm{BP} 4$ & N.E. & $.67-15$ TOA & $9.63 \mathrm{E}-04$ & 996 & \\
\hline $12 / 14 / 90$ & $\mathrm{CO}-\mathrm{BP} 4 \mathrm{a}$ & N.E. & $.92-15 \mathrm{TOA}$ & $7.83 \mathrm{E} .04$ & 810 & \\
\hline $12 / 14 / 90$ & CO-BPS & S.W. & $.67-15 \mathrm{TOA}$ & 4.17E-04 & 431 & \\
\hline $12 / 14 / 90$ & CO-BP5a & S.W. & $.92-1 S^{\prime}$ TOA & $3.20 \mathrm{E}-04$ & 331 & \\
\hline $12 / 14 / 90$ & $\mathrm{CO}-\mathrm{BP} 6$ & N.W. & $.67-15$ TOA & $6.99 \mathrm{E}-04$ & 723 & \\
\hline $12 / 14 / 90$ & CO-BPóa & N.W. & $.92-15^{\prime} \mathrm{TOA}$ & $8.56 \mathrm{E}-04$ & 886 & \\
\hline $12 / / 17 / 91$ & CO-BP7a & N.E. & $6.7-8.0^{\prime} \mathrm{TOA}$ & $3.88 \mathrm{E}-04$ & 401 & \\
\hline $12 / 17 / 91$ & CO-BP8 & N.E. & $5.3-6.0^{\prime} \mathrm{TOA}$ & $2.25 \mathrm{E}-03$ & 2330 & \\
\hline $12 / 17 / 91$ & CO-BP9 & N.E. & $2.2-4.0^{\prime}$ TOA & $5.03 \mathrm{E}-04$ & 520 & \\
\hline $12 / 17 / 91$ & CO-BP10 & N.E. & $3.2-4.0^{\prime}$ TOA & $9.36 \mathrm{E}-04$ & 968 & \\
\hline $12 / 17 / 91$ & CO-BP11 & N.E. & $0.3-2.0^{\prime}$ TOA & $1.22 \mathrm{E}-04$ & 126 & \\
\hline
\end{tabular}




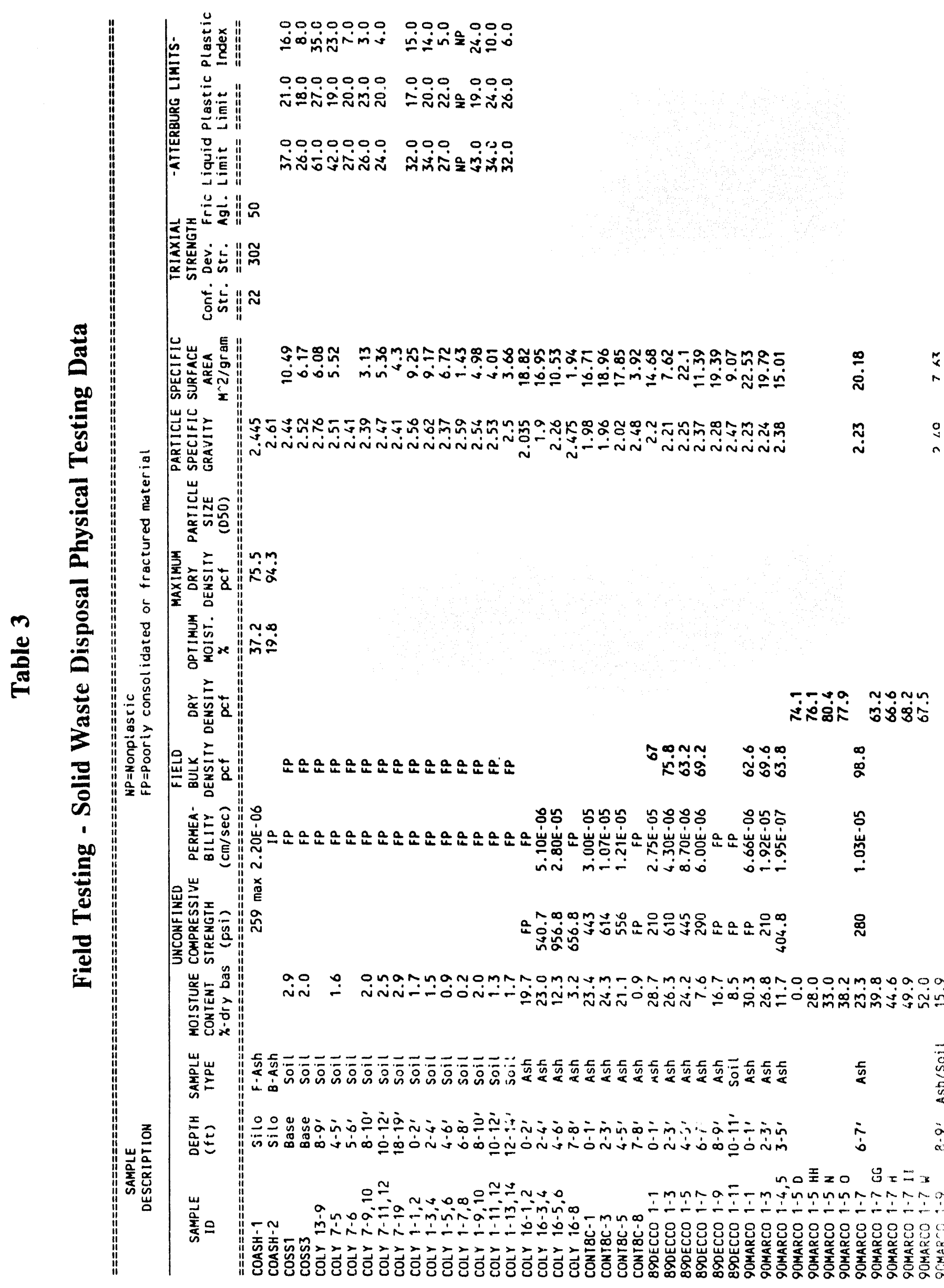




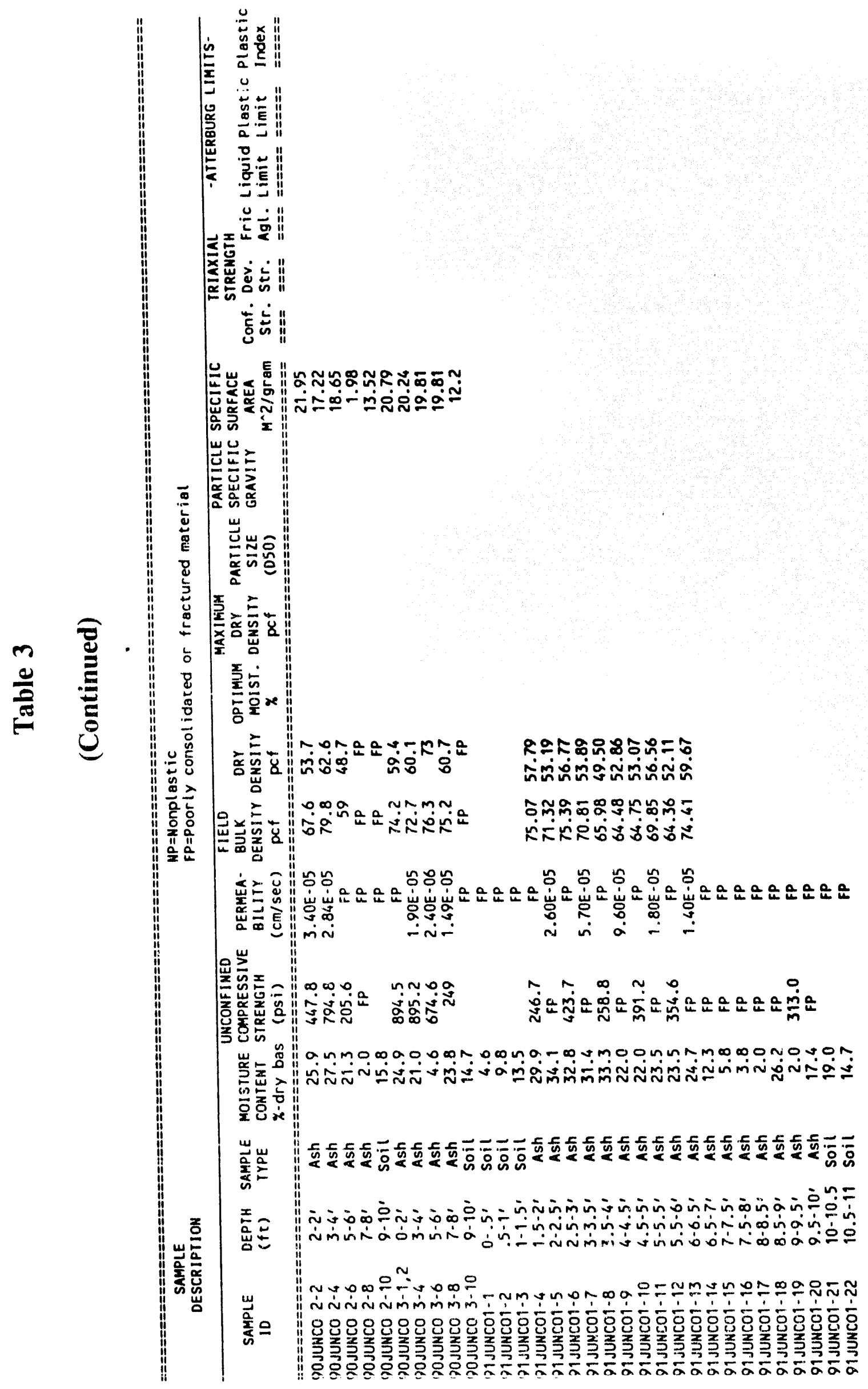




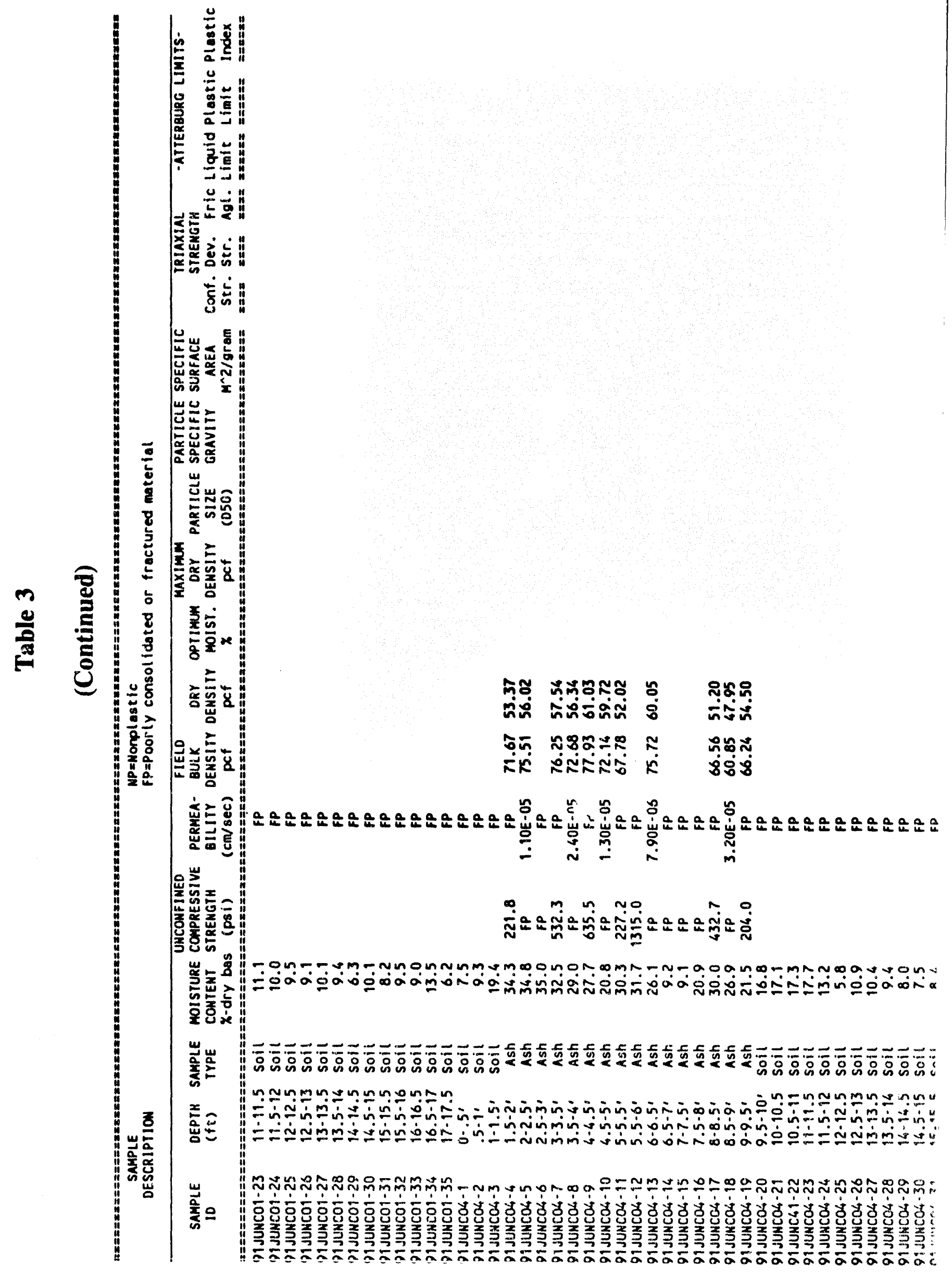




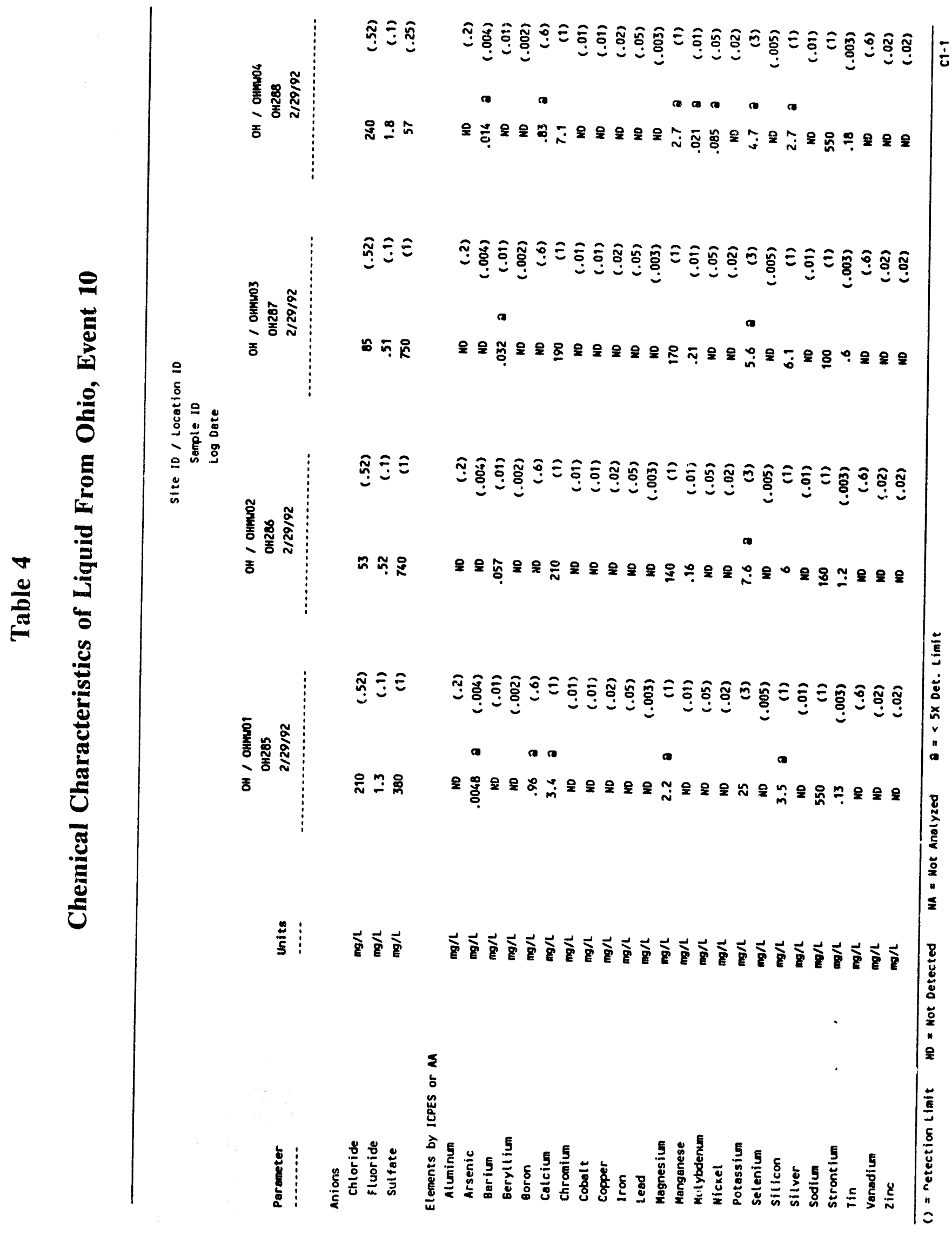



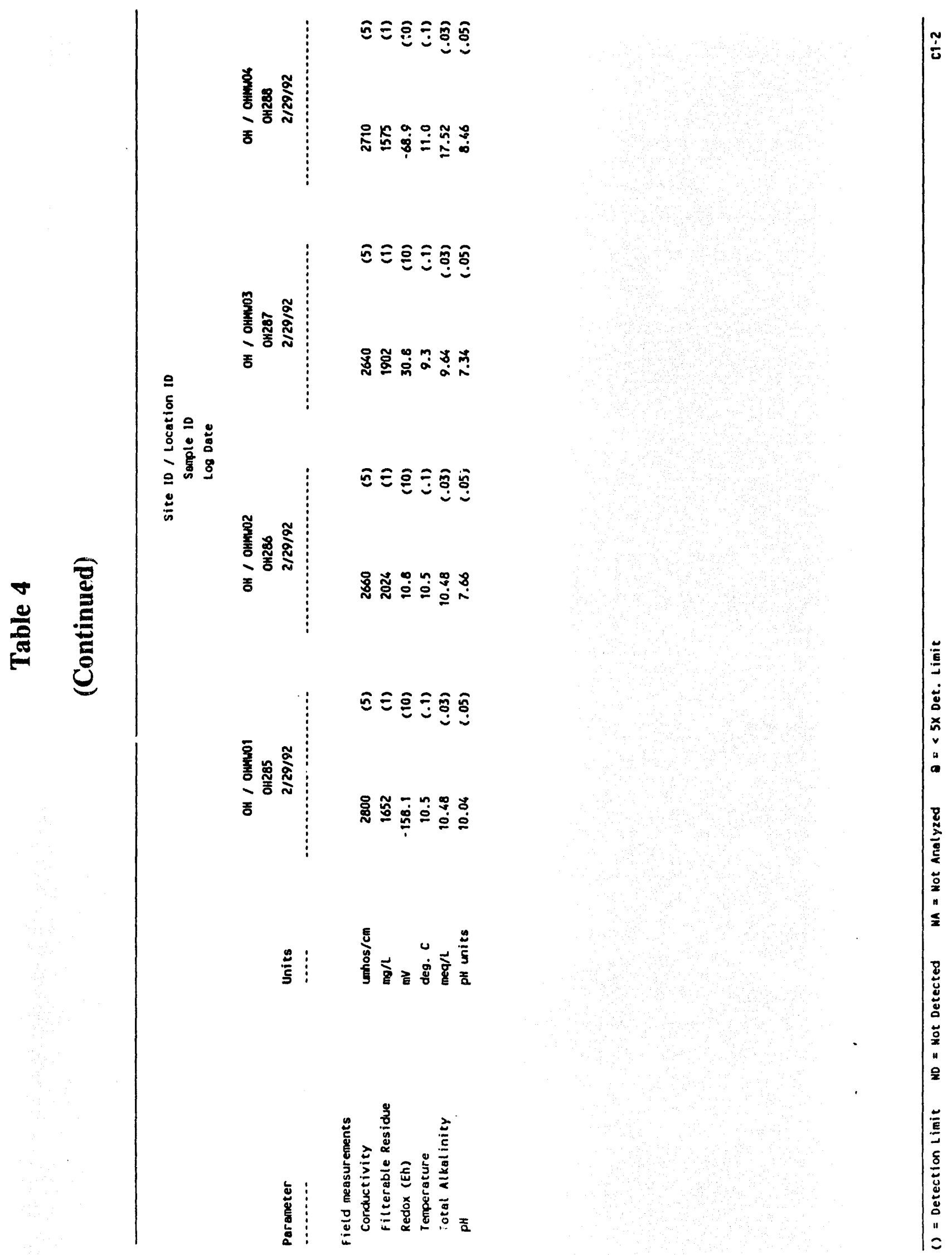


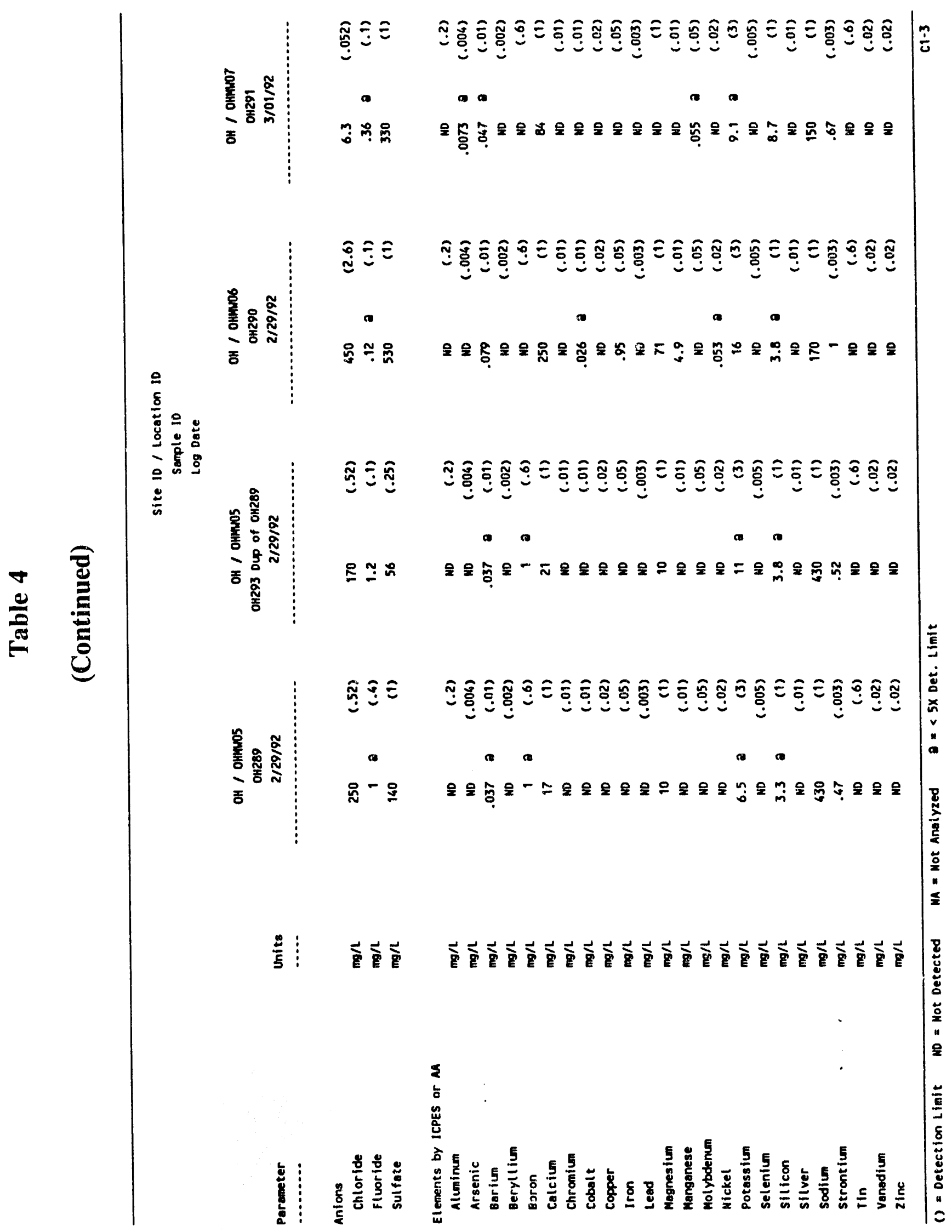




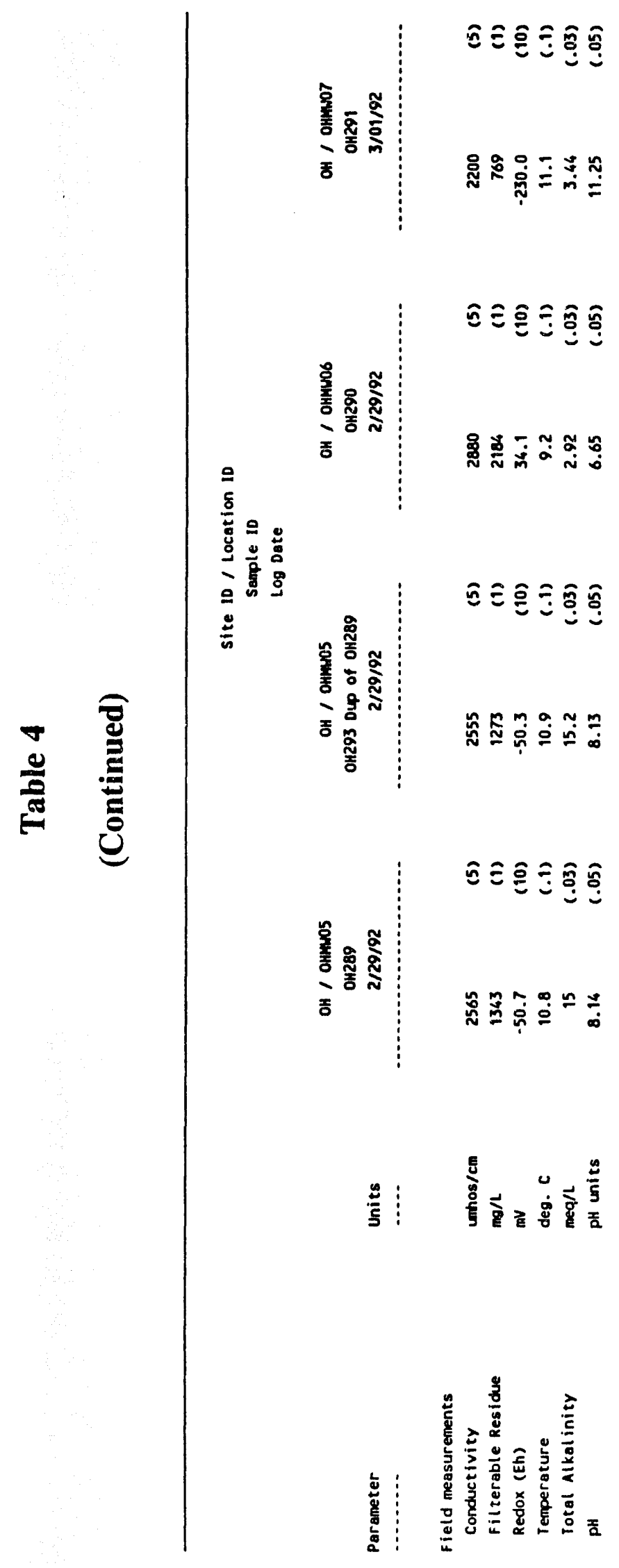




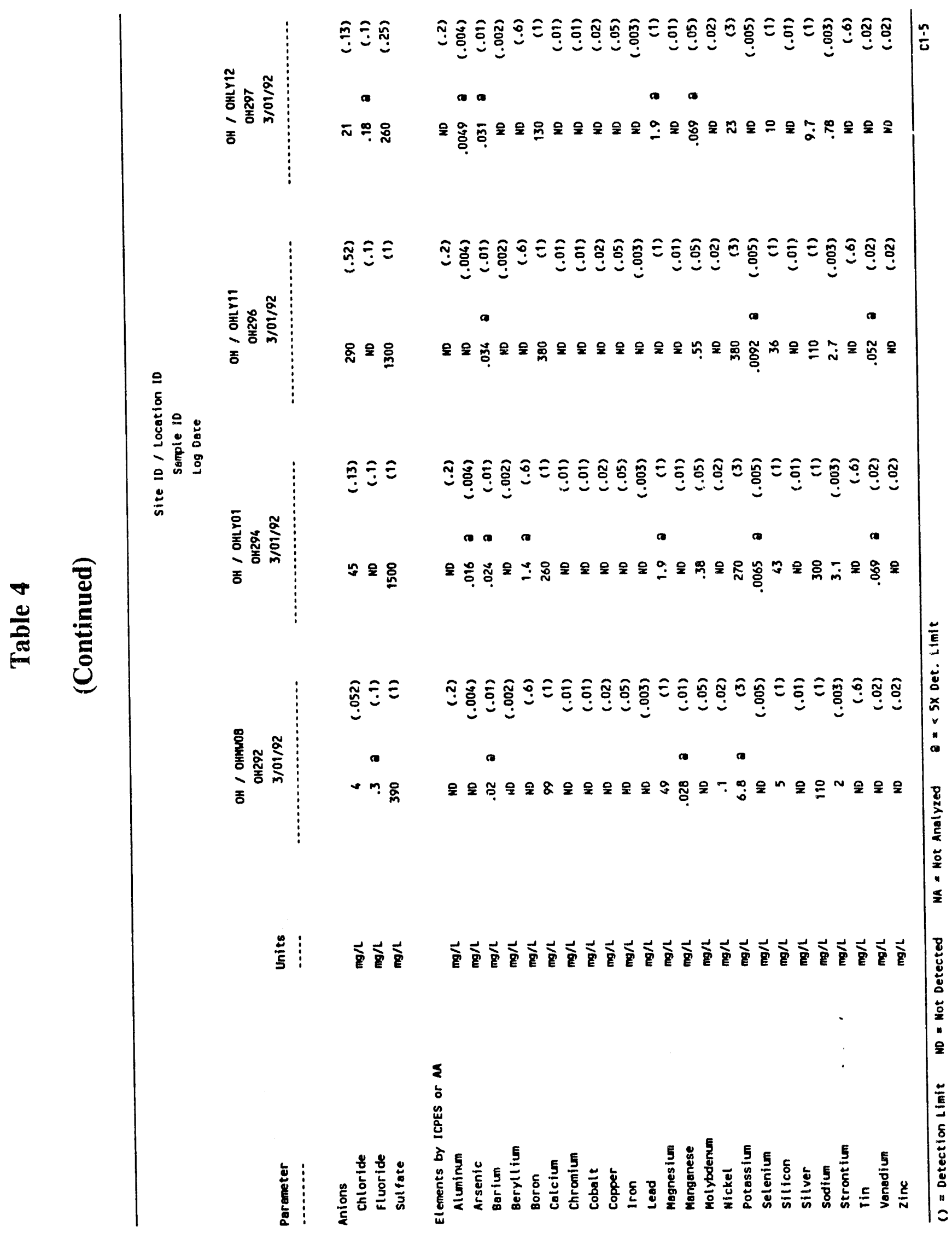




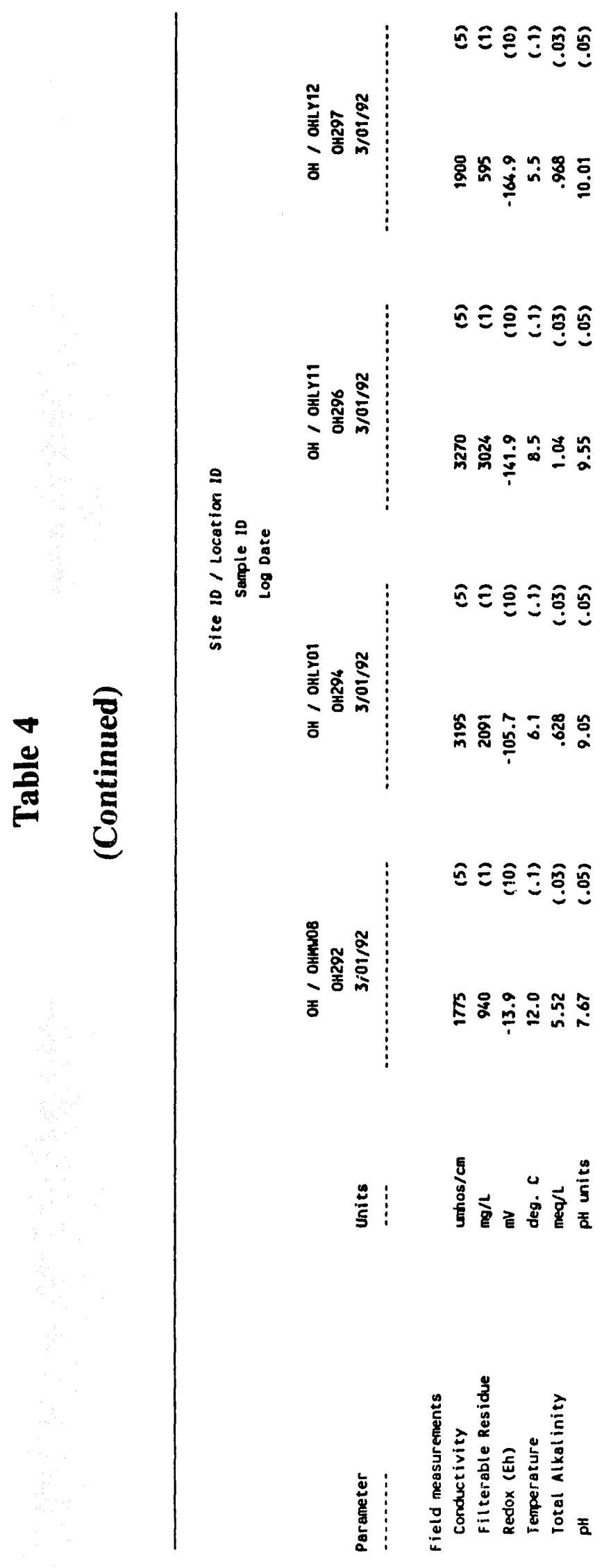




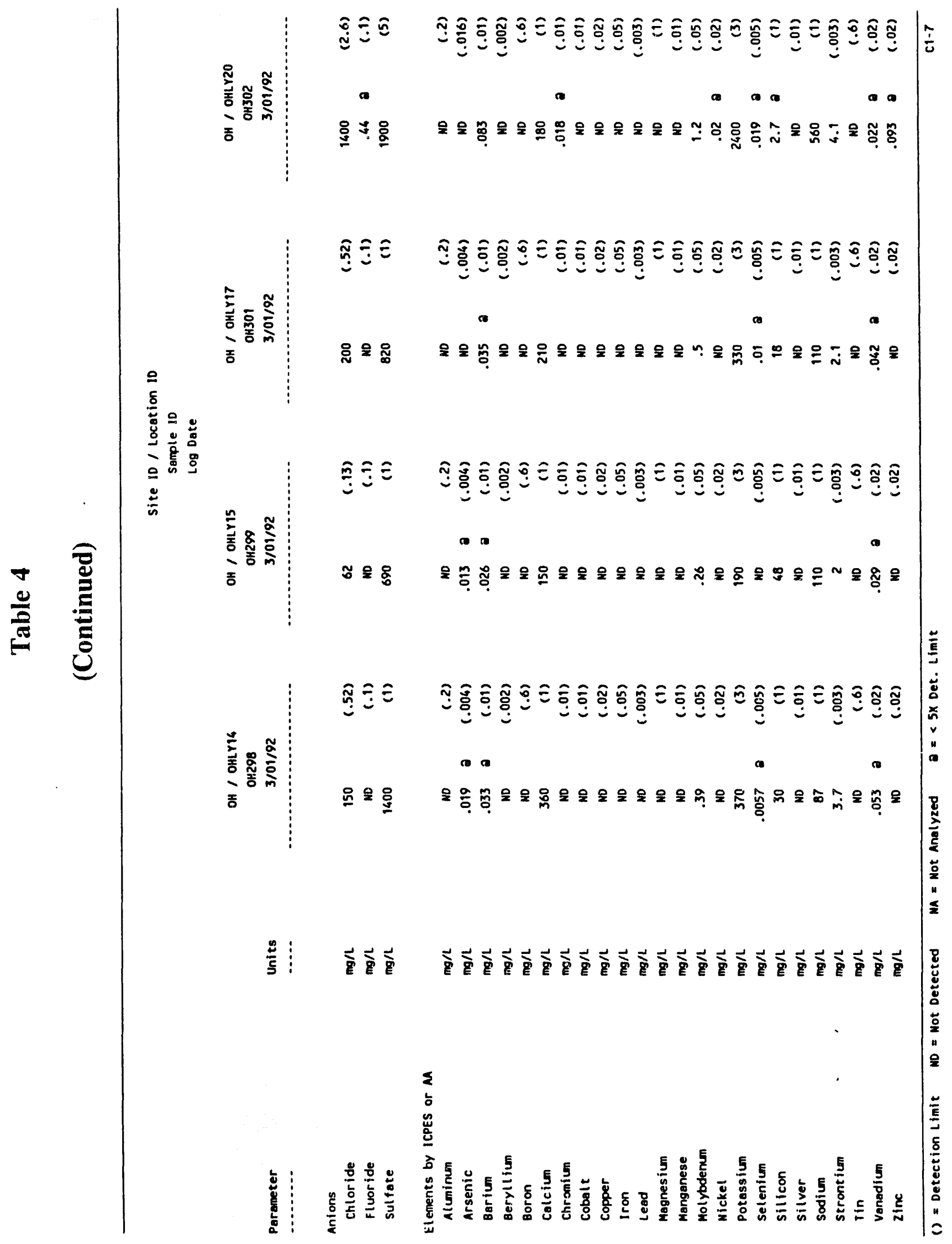




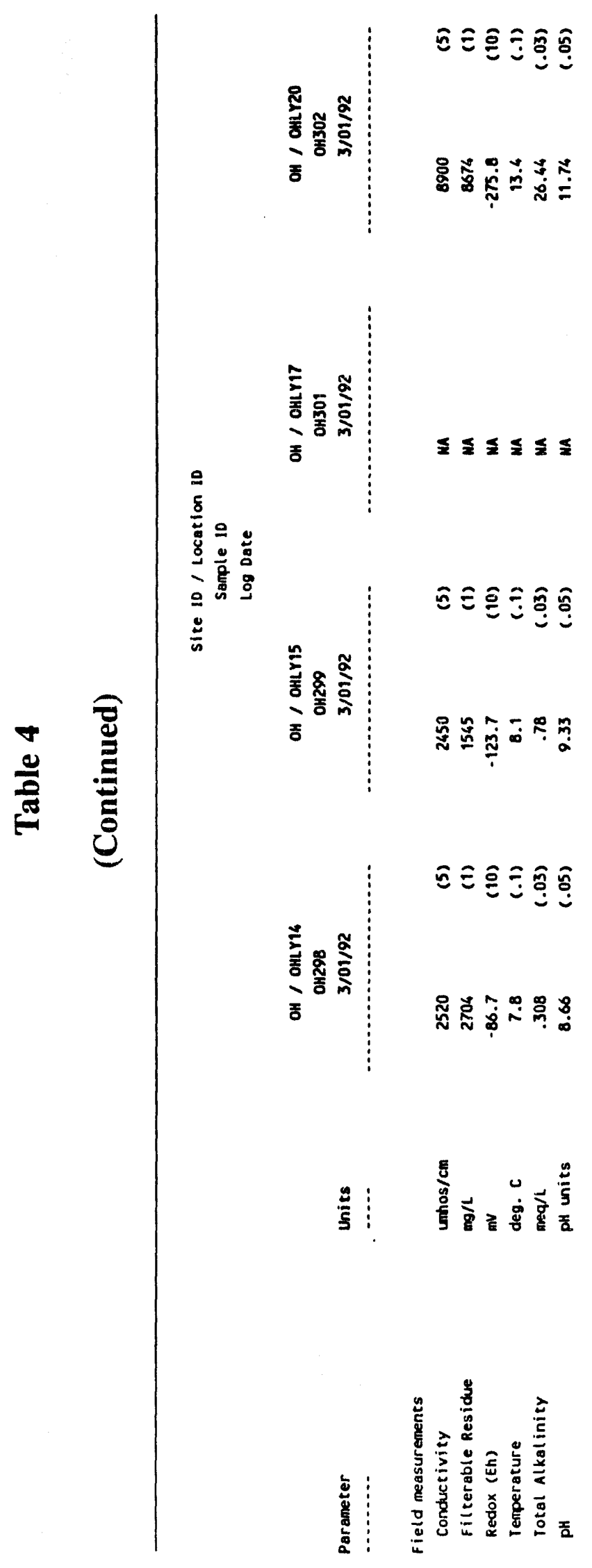




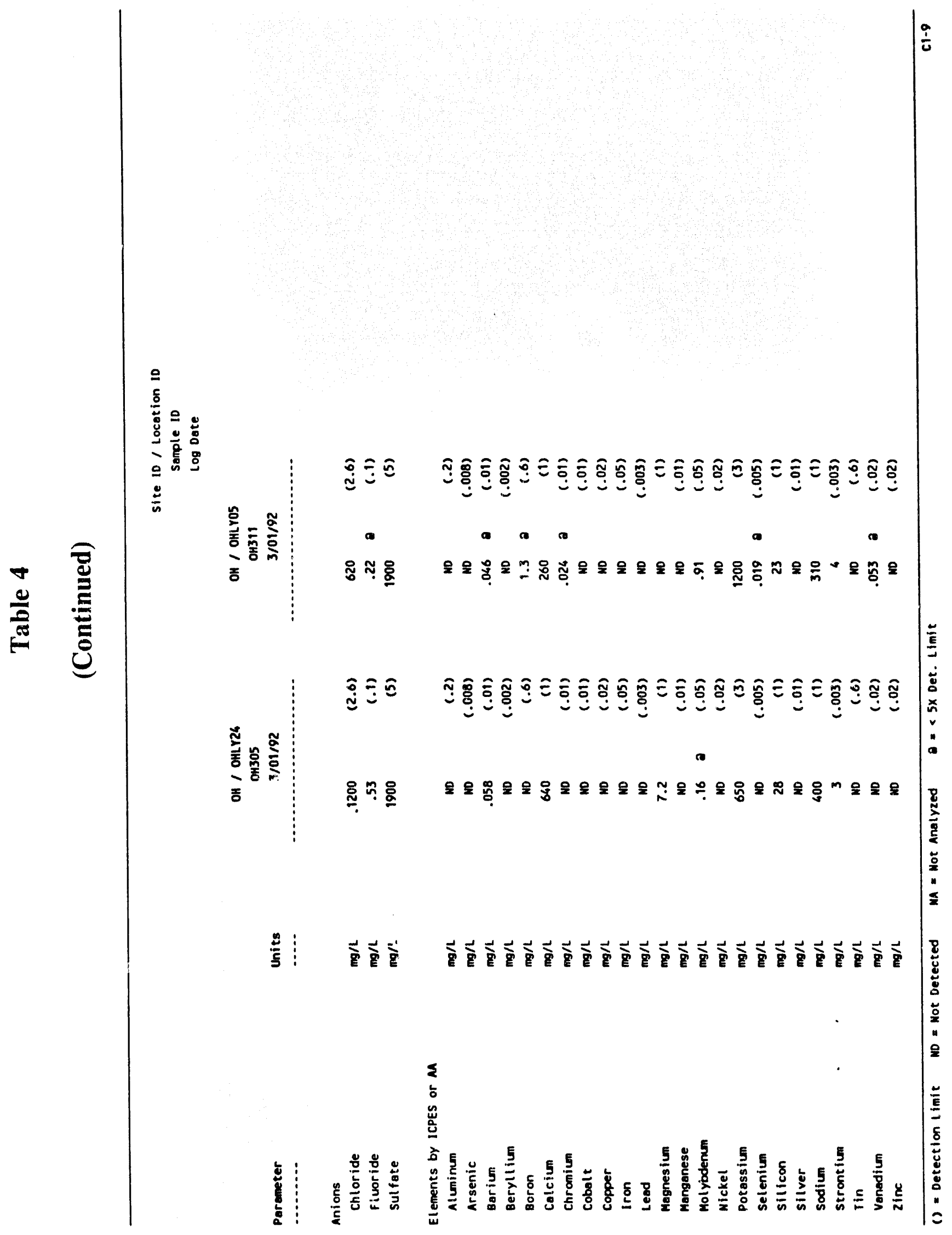




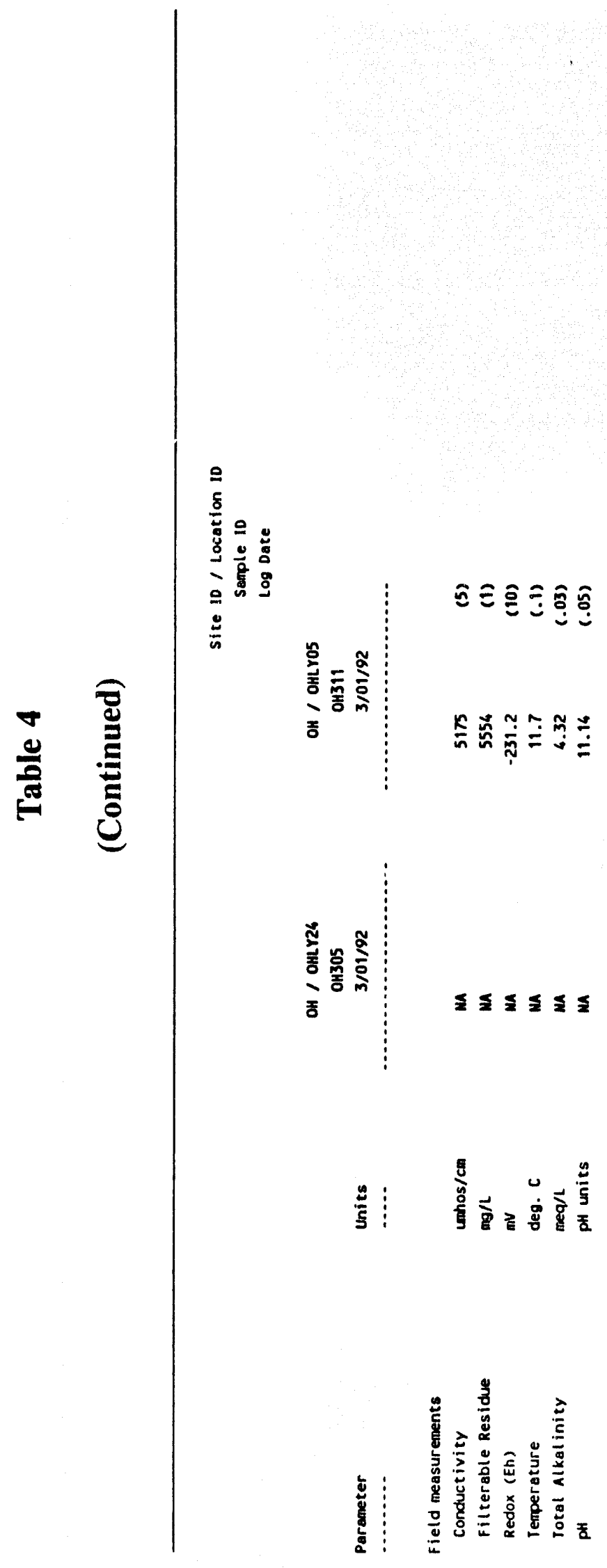




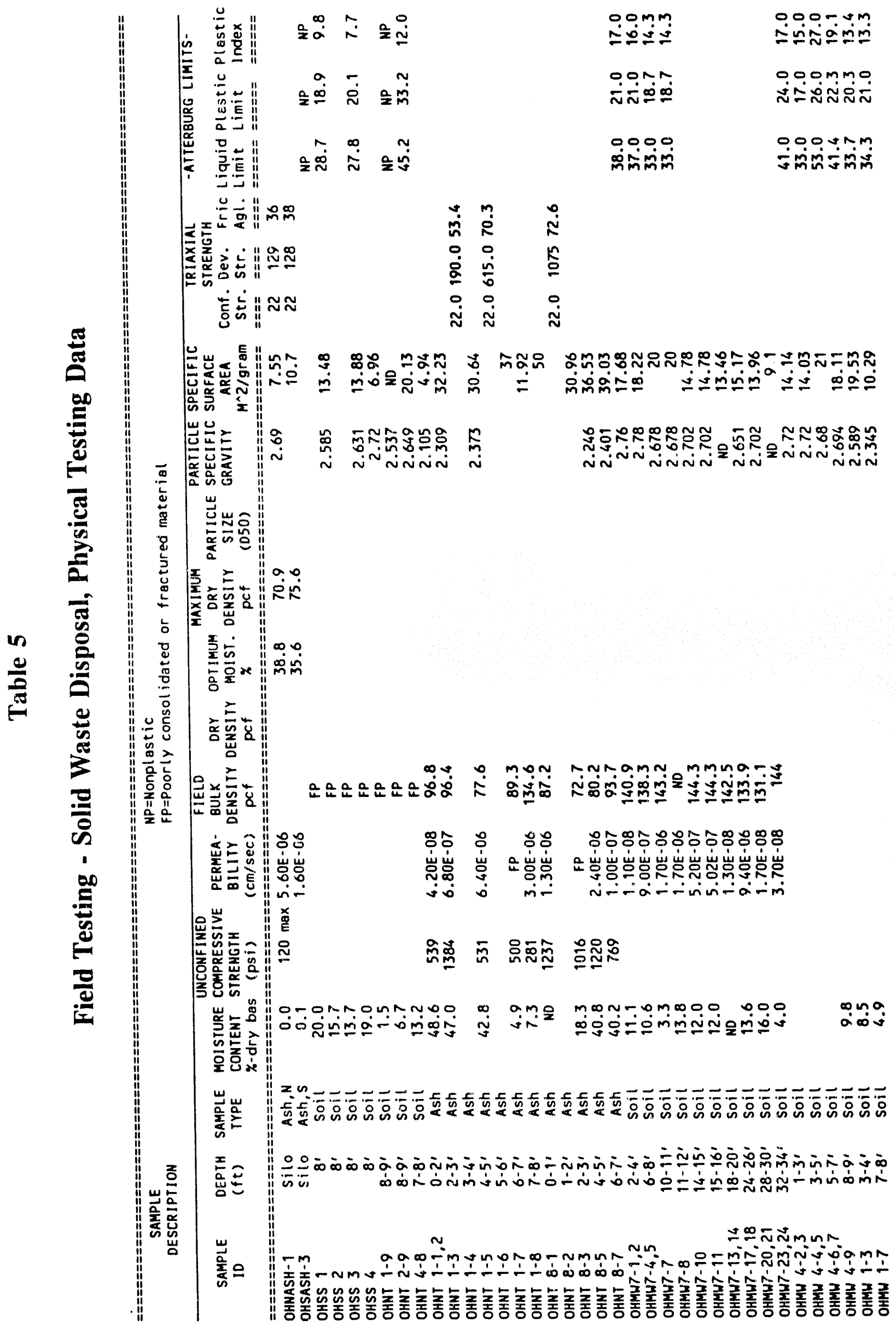




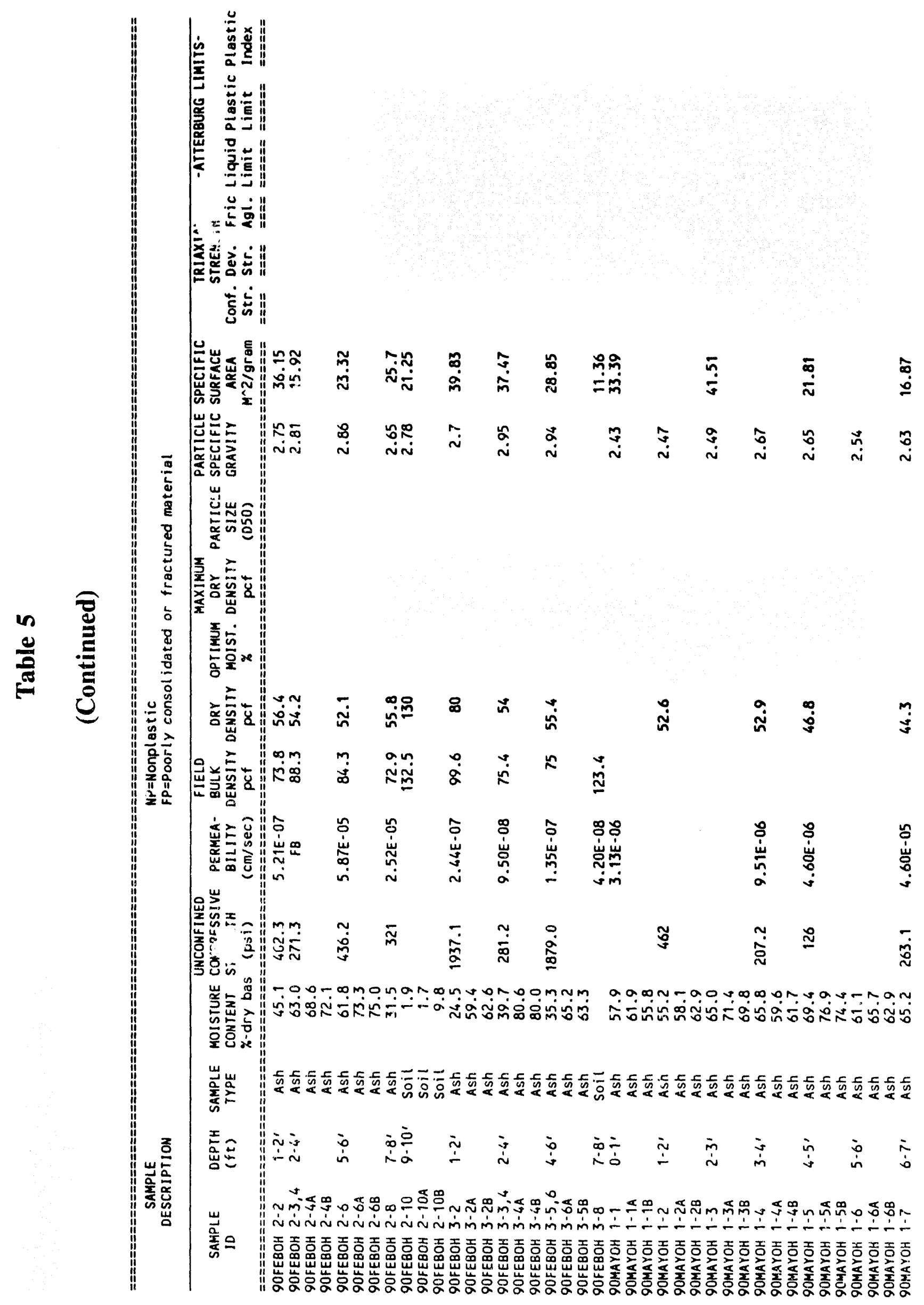




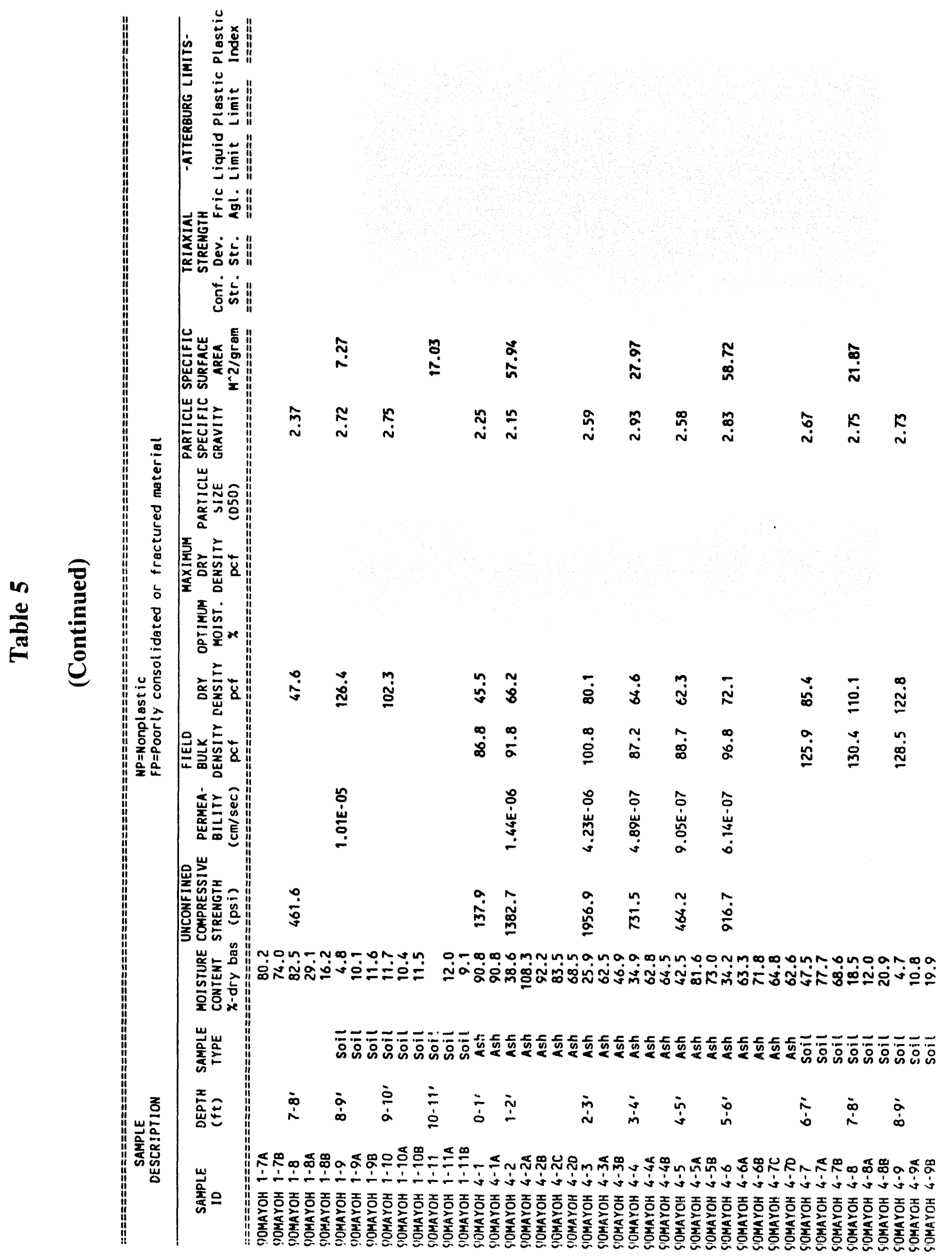




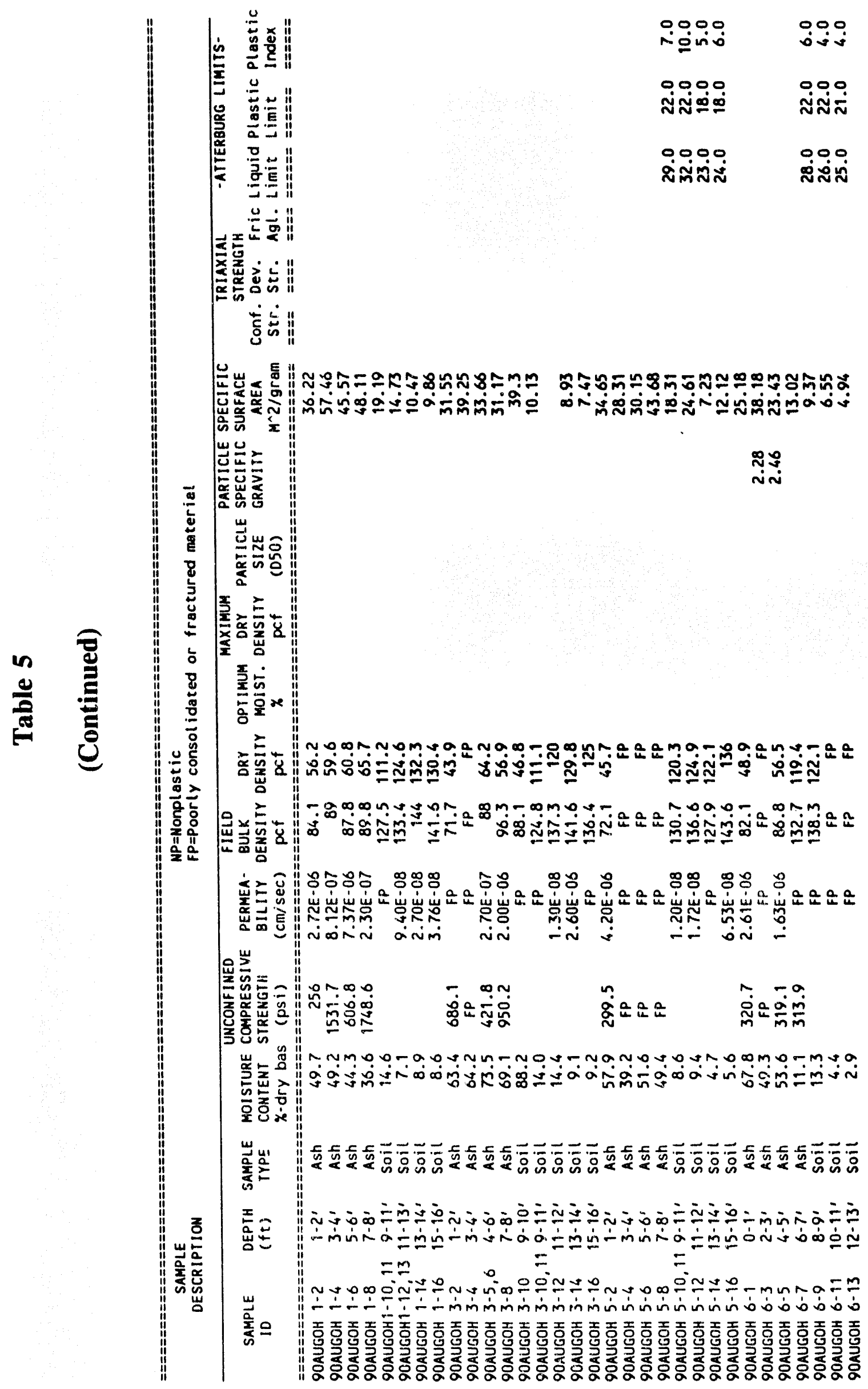




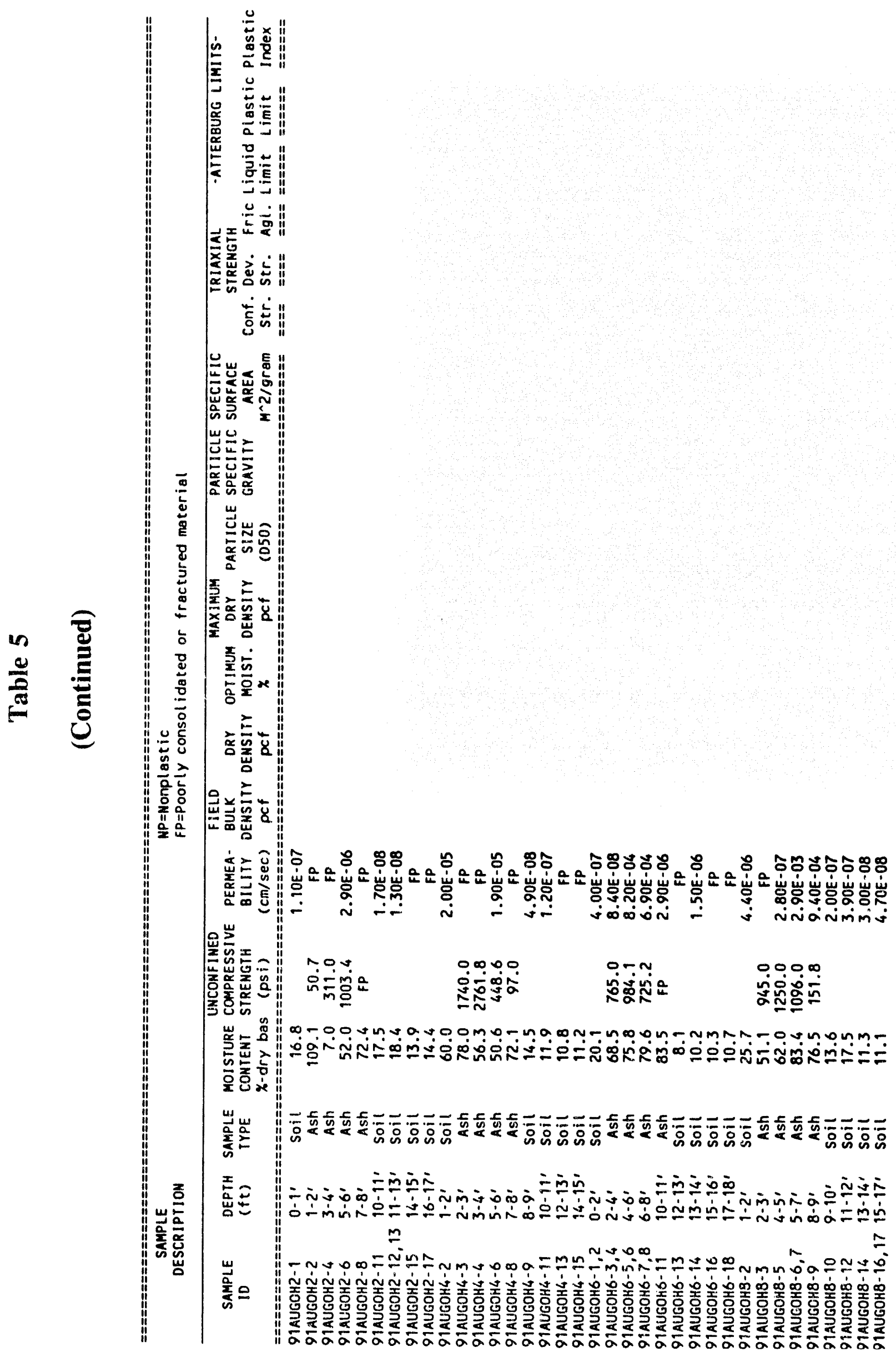




\section{Table 6}

\section{Field Testing - Solid Waste Disposal In-Situ Hydraulic Conductivity}

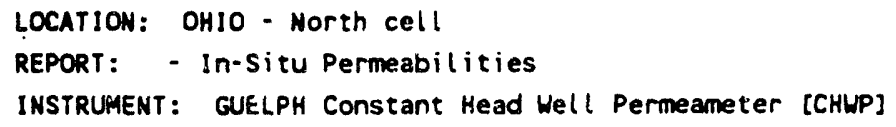

\begin{tabular}{|c|c|c|c|c|c|c|}
\hline \multicolumn{7}{|c|}{ INTERVAL } \\
\hline & & LOC. & TESTED & Kfs & Kfs & \\
\hline OATE & TEST\# & QUAD & $(f t-r e f)$ & $(\mathrm{cm} / \mathrm{sec})$ & $(f t / y r)$ & COMMENTS \\
\hline \multicolumn{7}{|c|}{ 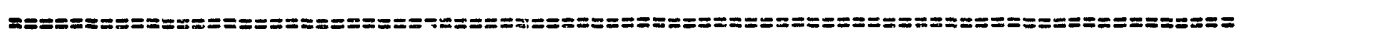 } \\
\hline $06 / 01 / 90$ & OHBP-1N & S.E. & $.23-1.1$ ron & $1.22 E-04$ & 126 & \\
\hline $06 / 06 / 90$ & OHBP $-5 \mathrm{~N}$ & S.W. & $.5-1.25$, TOA & $1.28 \varepsilon-0.4$ & 132 & \\
\hline $06 / 06 / 90$ & OHBP- GN & N.H. & $.67-1.5: \mathrm{TOA}$ & $5.55 E-05$ & 57 & \\
\hline $08 / 07 / 90$ & OHBP-7N & N.ti. & $.37-1.9$ TOA & $9.35 E-05$ & 97 & \\
\hline $08 / 07 / 90$ & OHBP- TON & N.W. & $.29-1.5$ ' TOA & $4.31 E-04$ & 445 & $0.5 \mathrm{ft}=$ probable fracture zone \\
\hline $08 / 07 / 90$ & OHBP- TCN & N.W. & $.71 \cdot 1.5, \mathrm{rOA}$ & $9.10 E-05$ & 94 & \\
\hline $08 / 07 / 90$ & $O H B D-3 N$ & S.E. & $.6-1.33, \mathrm{TOA}$ & $1.36 E-04$ & 140 & $0.7 \mathrm{ft}=$ probable fracture zone \\
\hline $08 / 07 / 90$ & OHBP-8bN & S.E. & $.8-1.33$, TOA & $5.61 E-05$ & 58 & \\
\hline $08 / 31 / 91$ & OHBP-9N & S.E. & $0.0-2.0^{\prime}$ TOA & $1.09 E-04$ & 112 & \\
\hline $08 / 31 / 91$ & OHRP-10N & Cntr & $6.0-8.5$ ' TOA & $1.49 E-05$ & 15 & \\
\hline $08 / 31 / 91$ & OHBP-11N & Cntr & $4.0-6.0^{\prime}$ TOA & $4.02 E-05$ & 42 & \\
\hline $08 / 31 / 91$ & OHEP-12N & Cntr & $2.0-4.01$ TOA & $5.13 E-05$ & 53 & \\
\hline $08 / 31 / 91$ & OHBP-13N & Contr & $0.6-.42^{\prime}$ cap & $3.88 E-04$ & 401 & \\
\hline $11 / 19 / 91$ & OHBP-14N & M.E. & $0.0-2.0$ t ton & $1.00 E-04$ & 103 & \\
\hline $11 / 19 / 91$ & OHBP-15N & N.E. & $2.0-4.01$ TOA & $3.06 E \cdot 05$ & 32 & \\
\hline $11 / 19 / 91$ & OHBP-16N & N.E. & $5.5-7.0^{\circ} \mathrm{TOA}$ & $7.35 t-05$ & 76 & \\
\hline $02 / 25 / 92$ & OHBP-17N & N.H. & $0.5-1.25^{\prime}$ TOA & $1.03 E-04$ & 107 & \\
\hline $02 / 25 / 92$ & OHBP-18N & N.H. & $0.0-2.17^{\prime}$ TOA & $3.95 E-05$ & 41 & \\
\hline $02 / 25 / 92$ & OHBP-19N & N.H. & $4.0-6.17^{\prime}$ TOA & $5.22 E-05$ & 54 & \\
\hline
\end{tabular}




\section{Table 6}

\section{(Continued)}

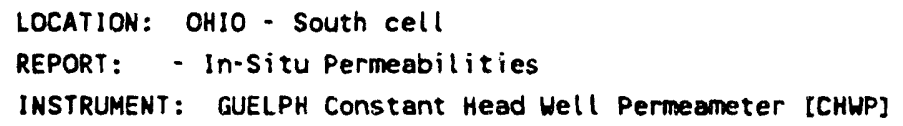

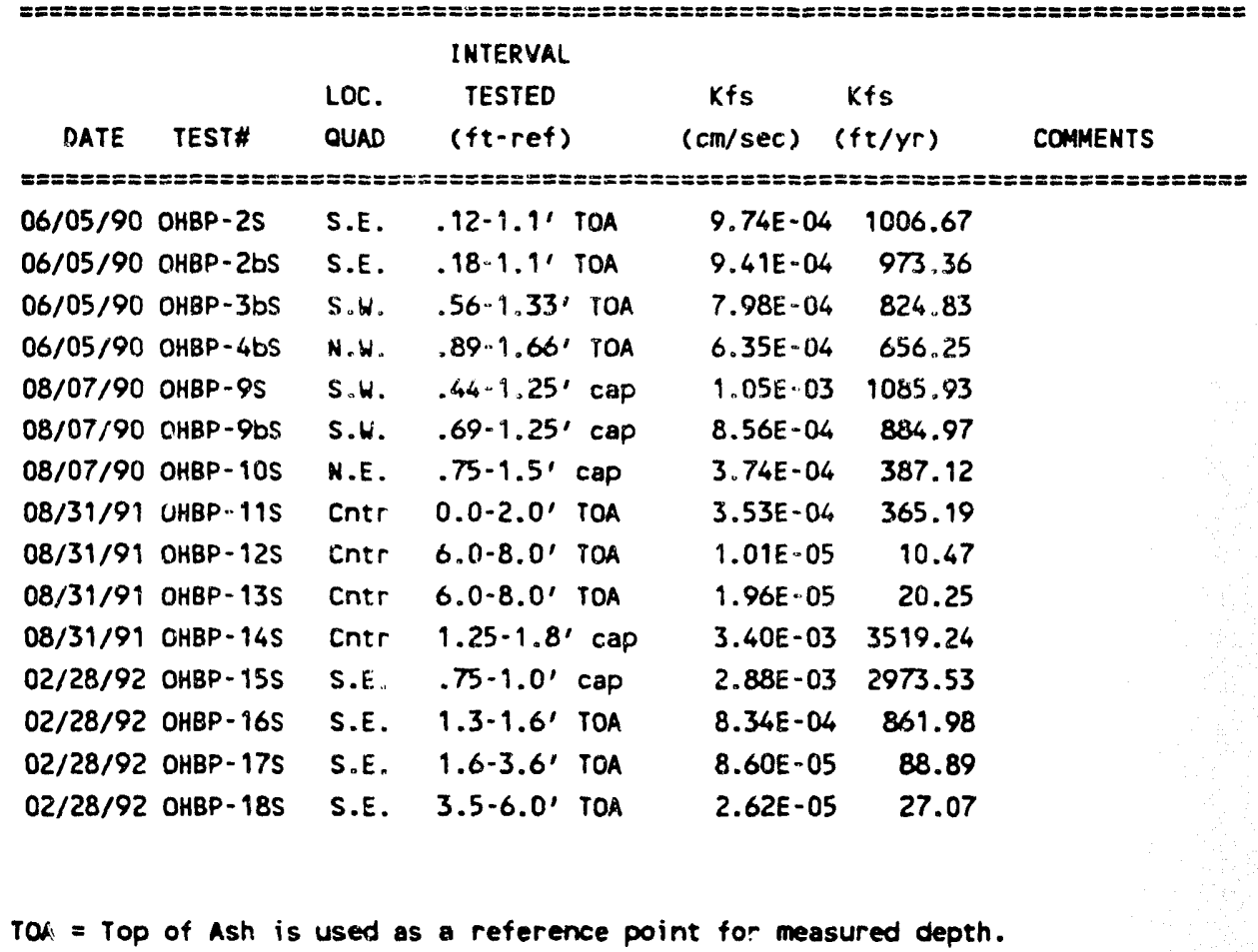




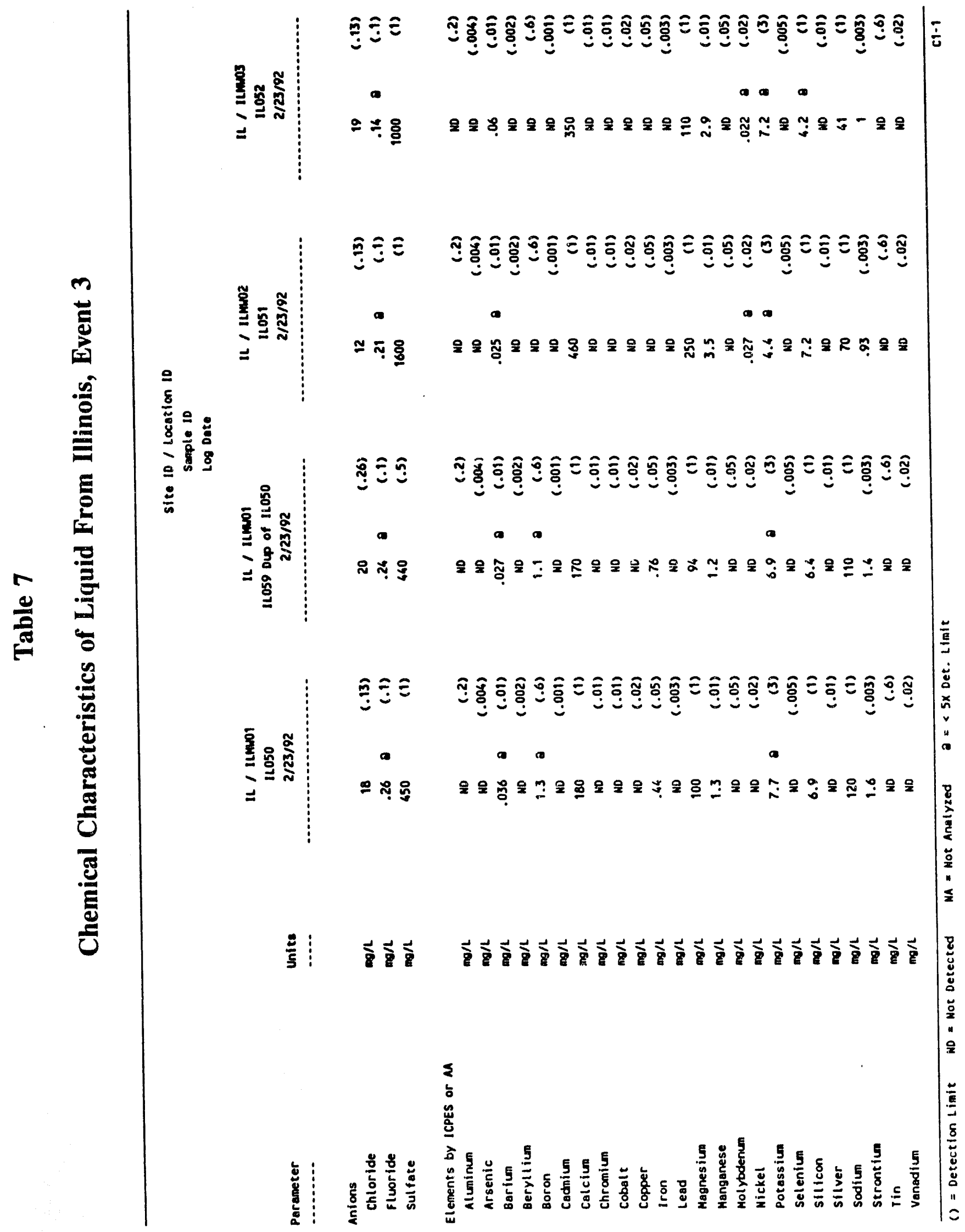




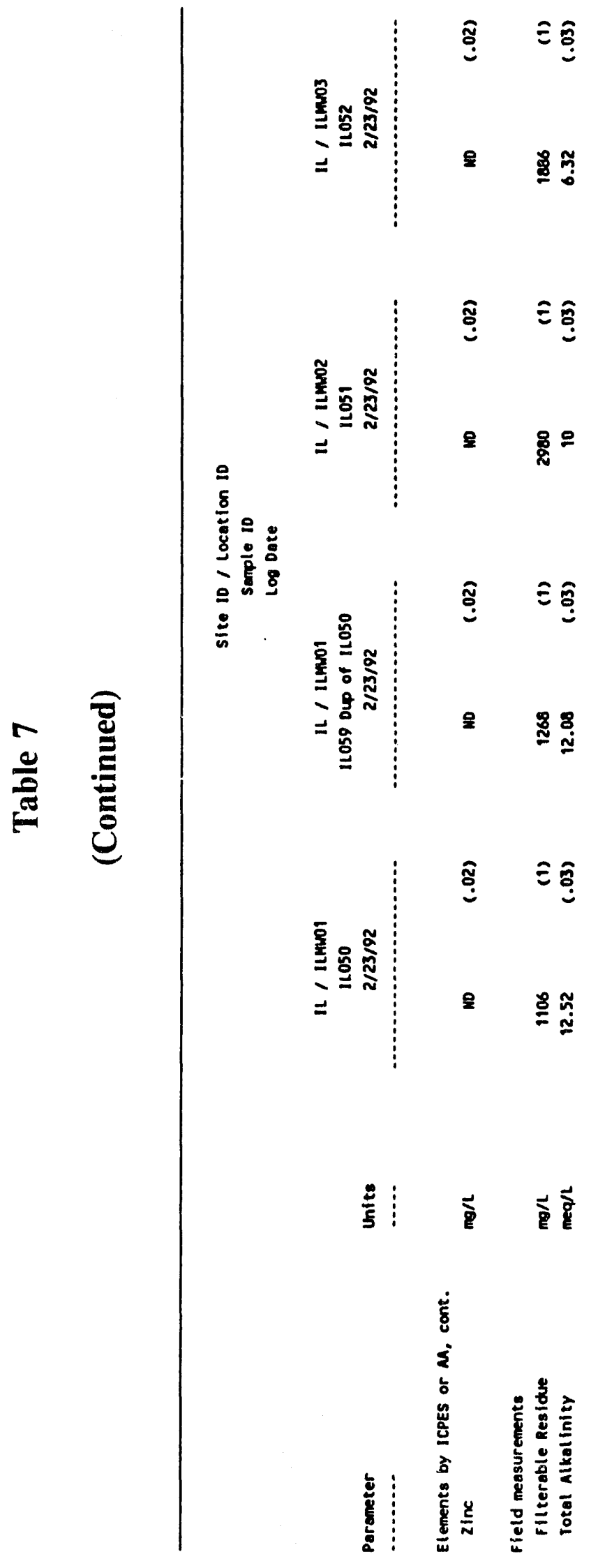




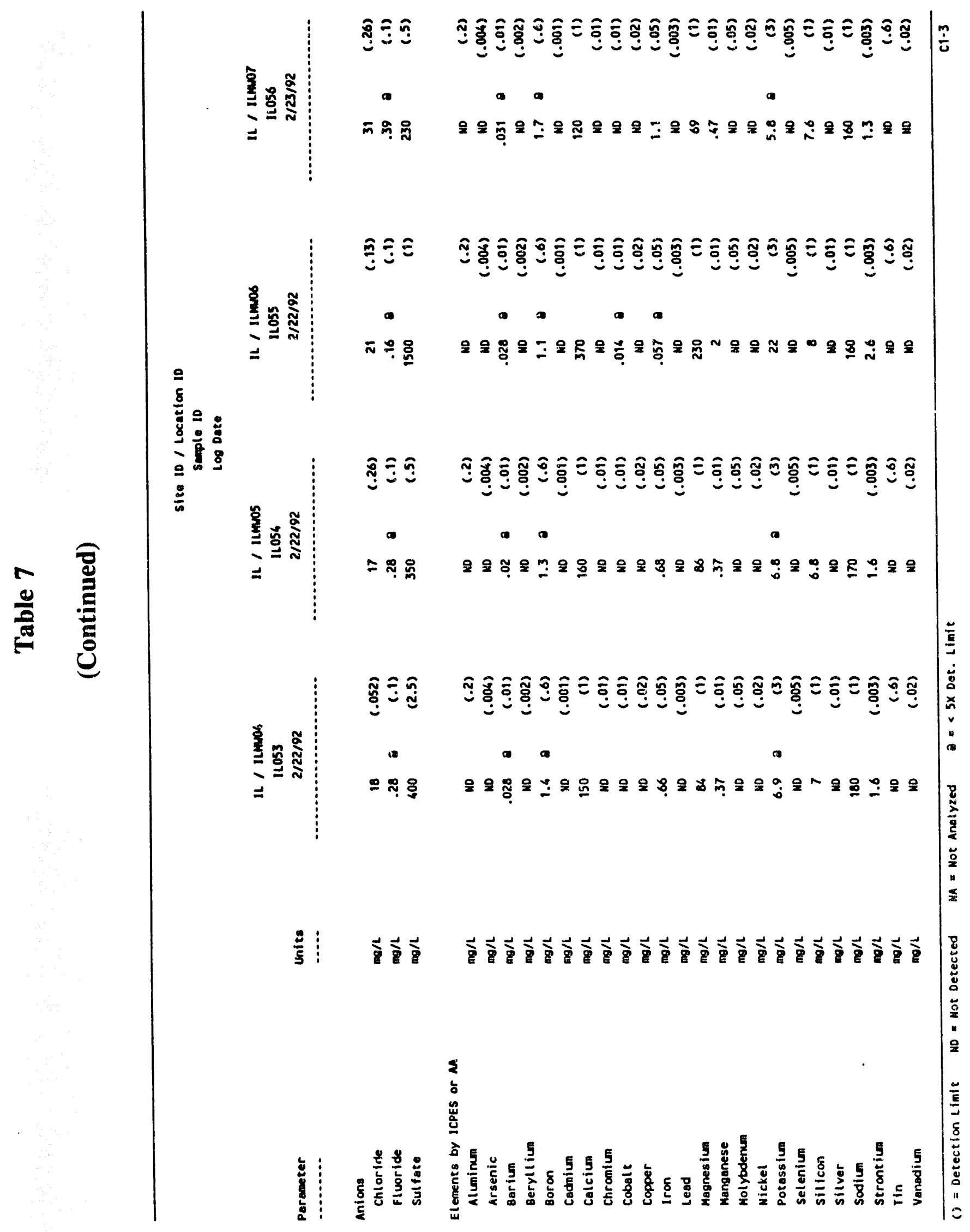




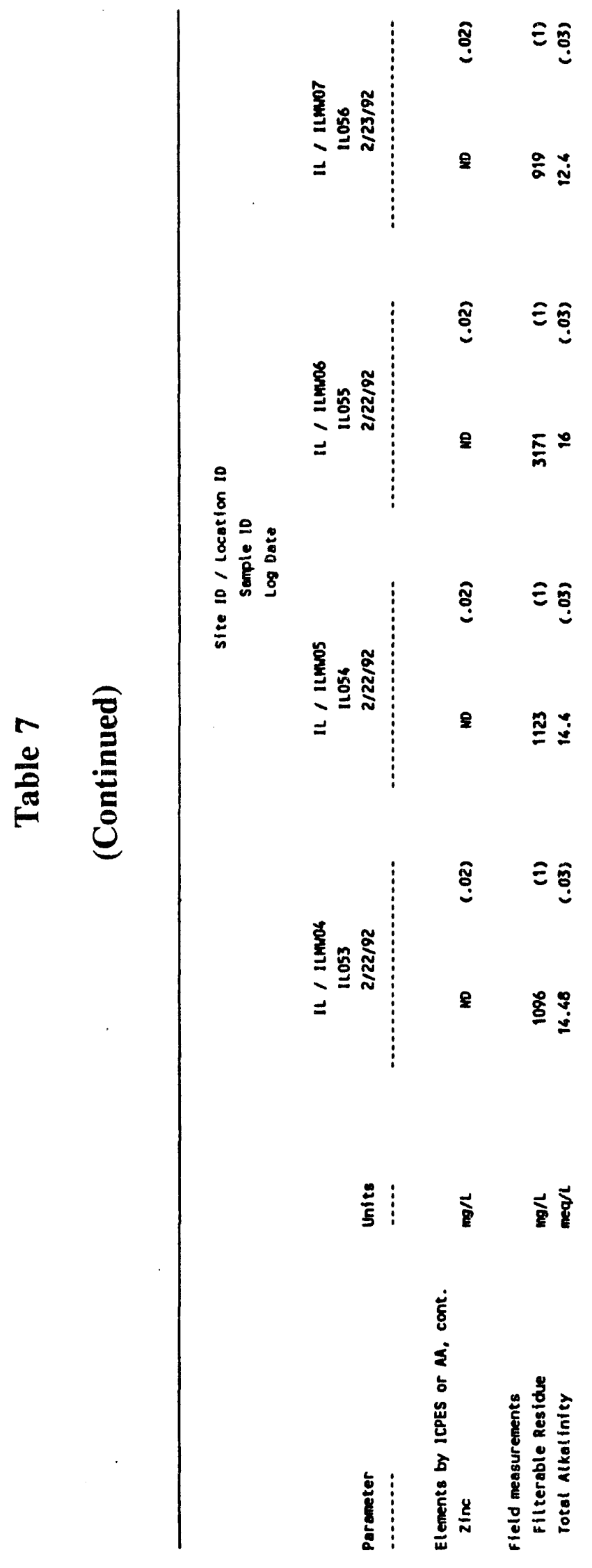

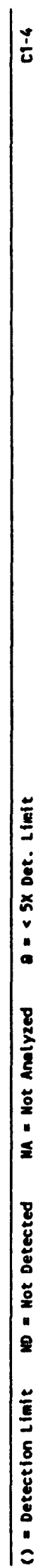




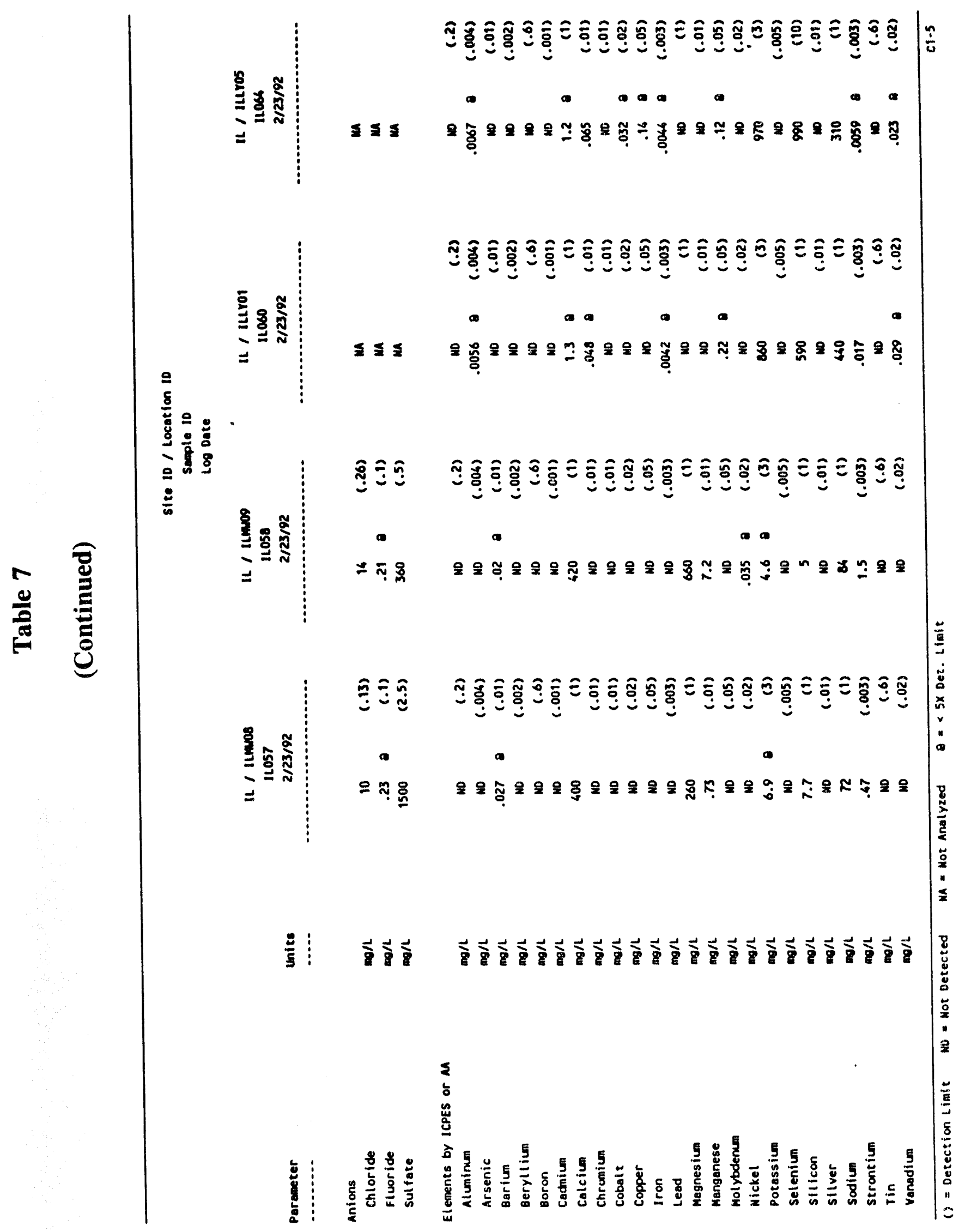




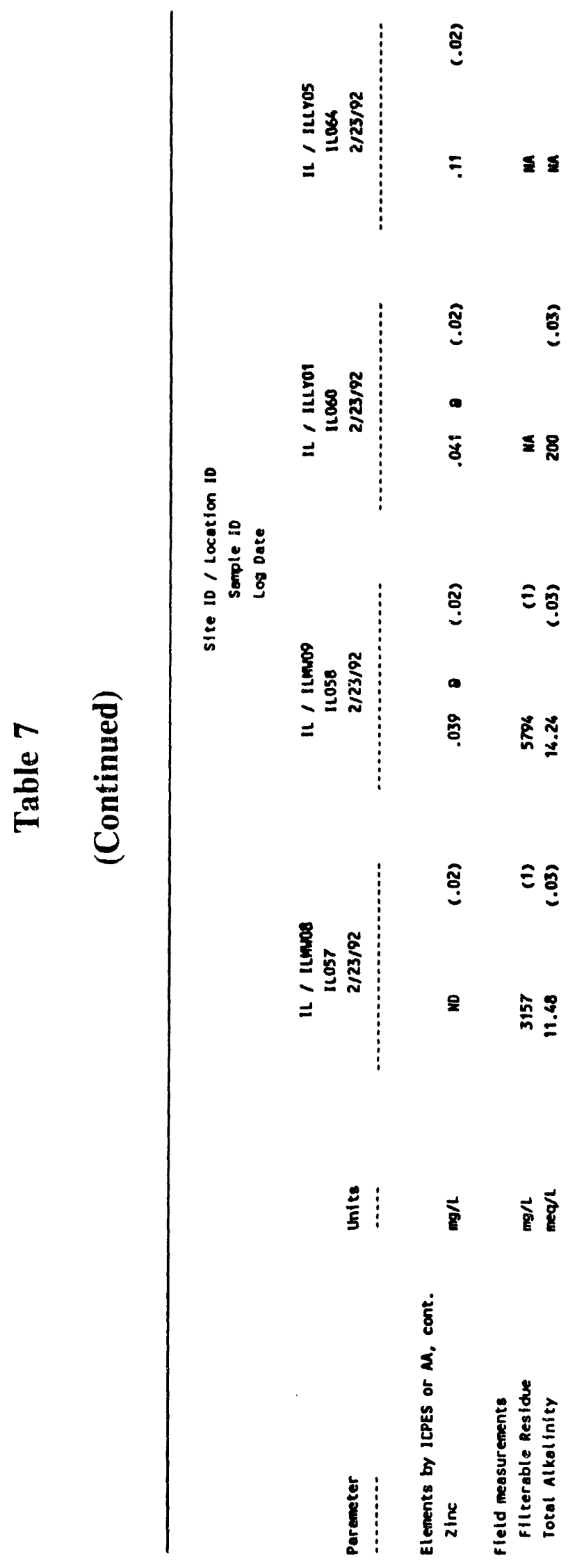

| 


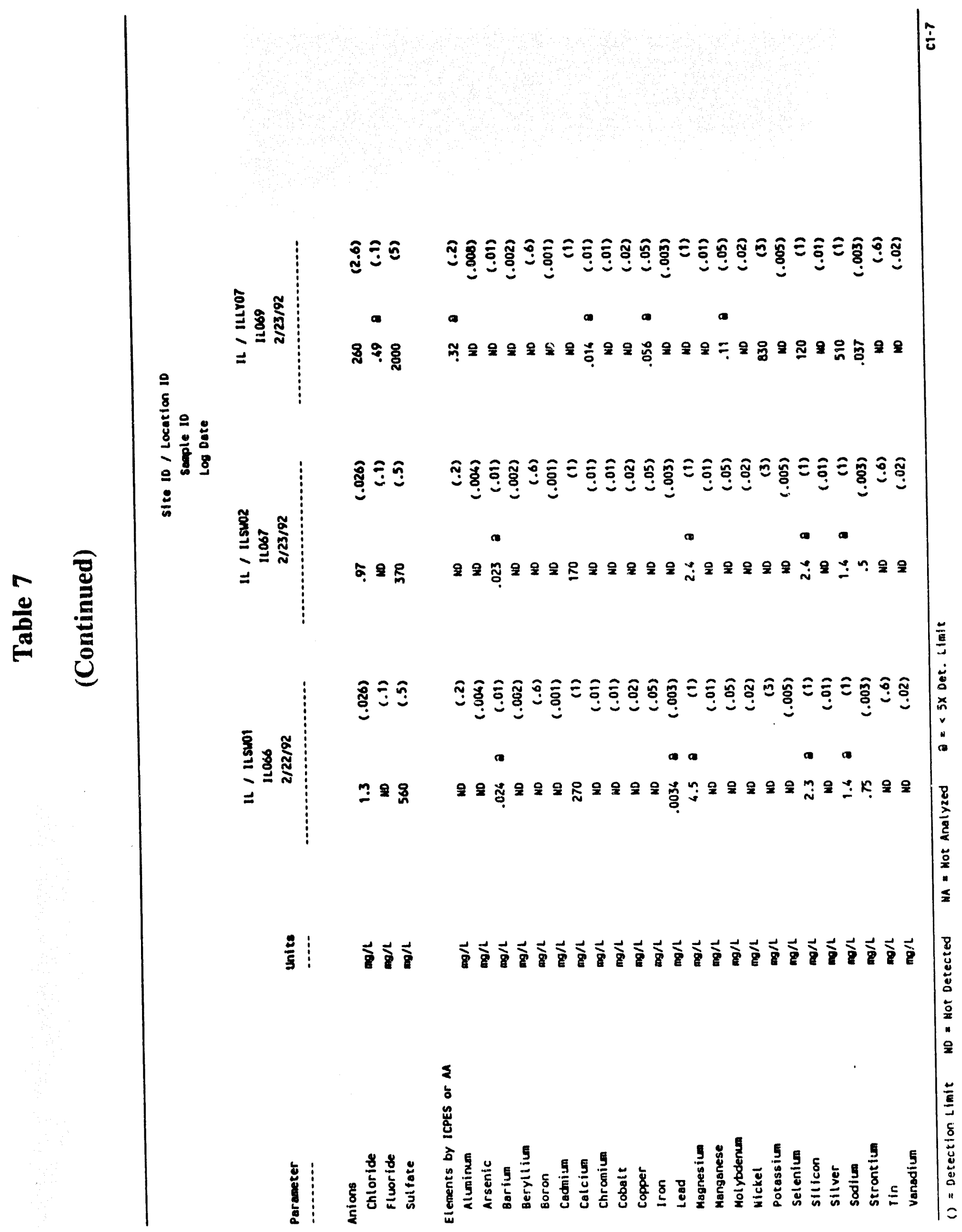




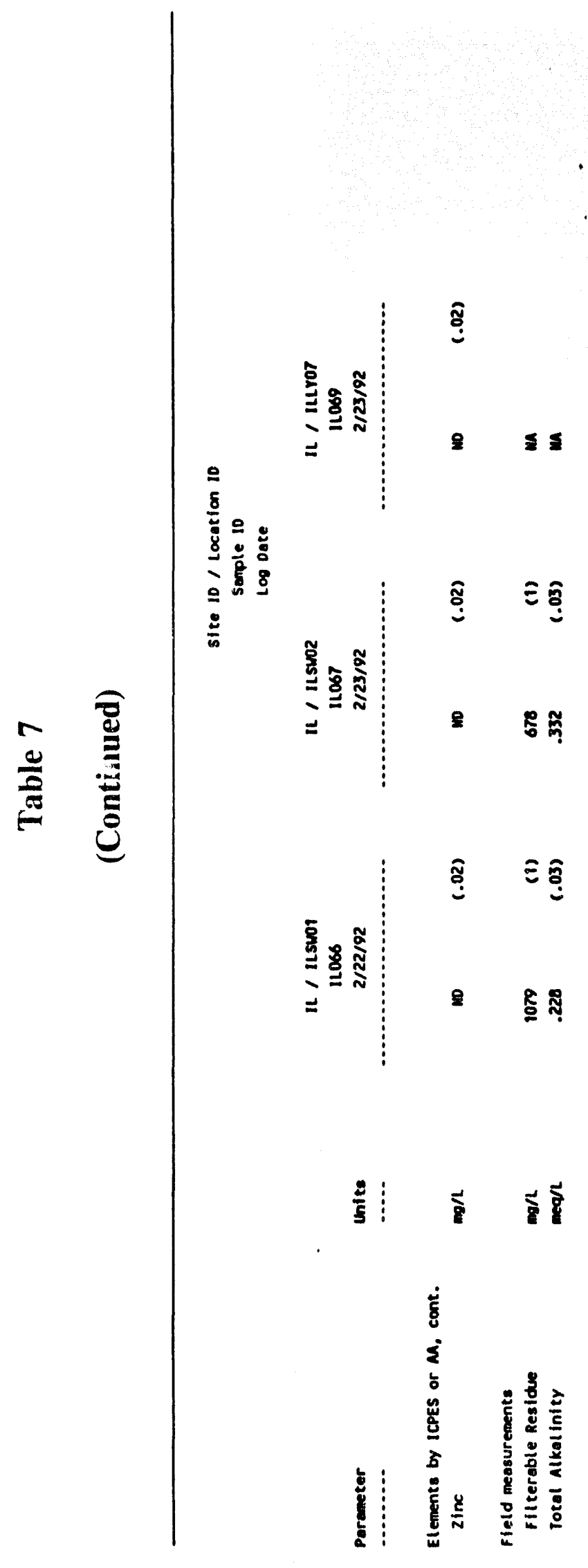

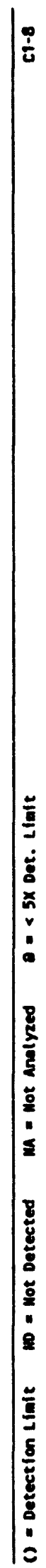




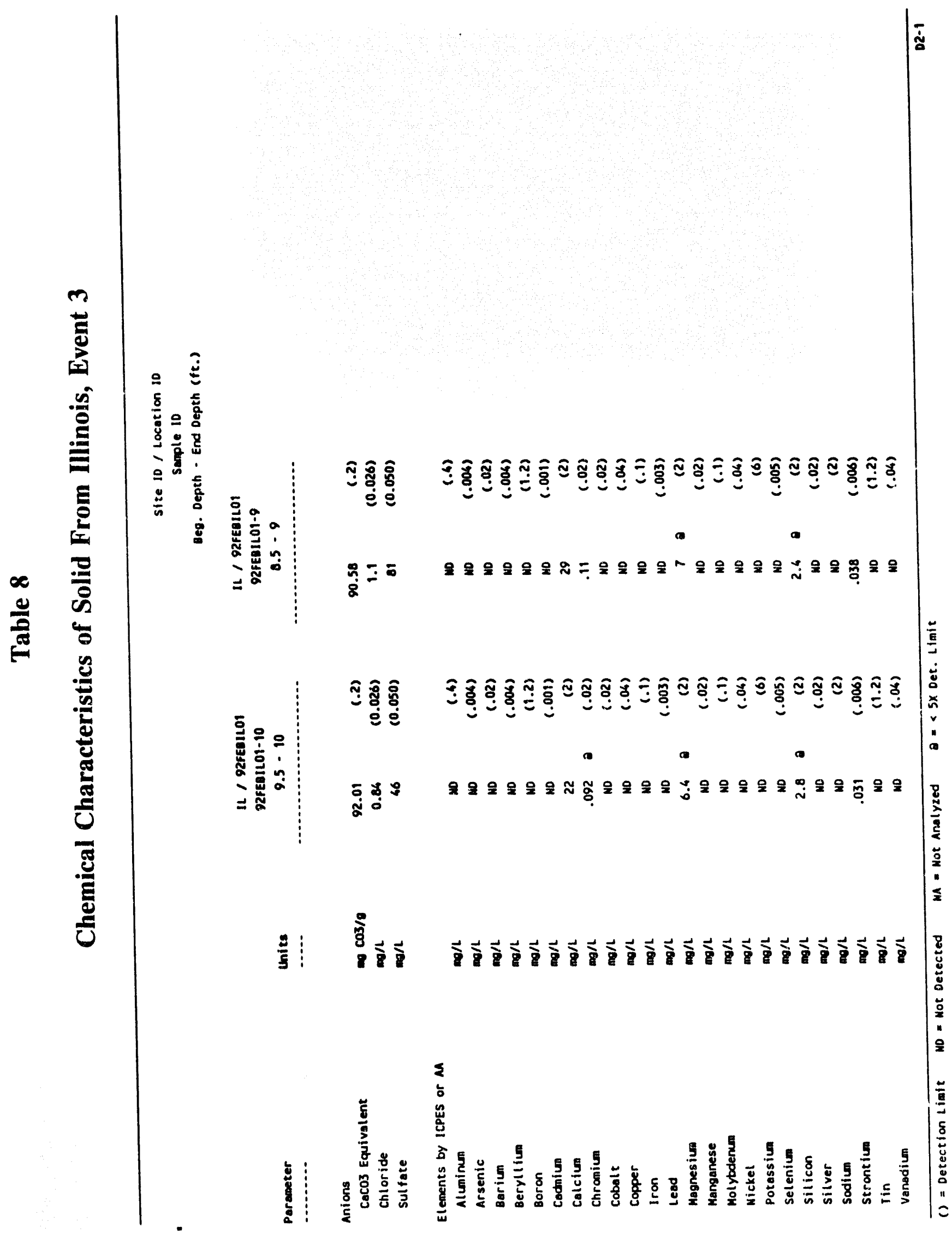




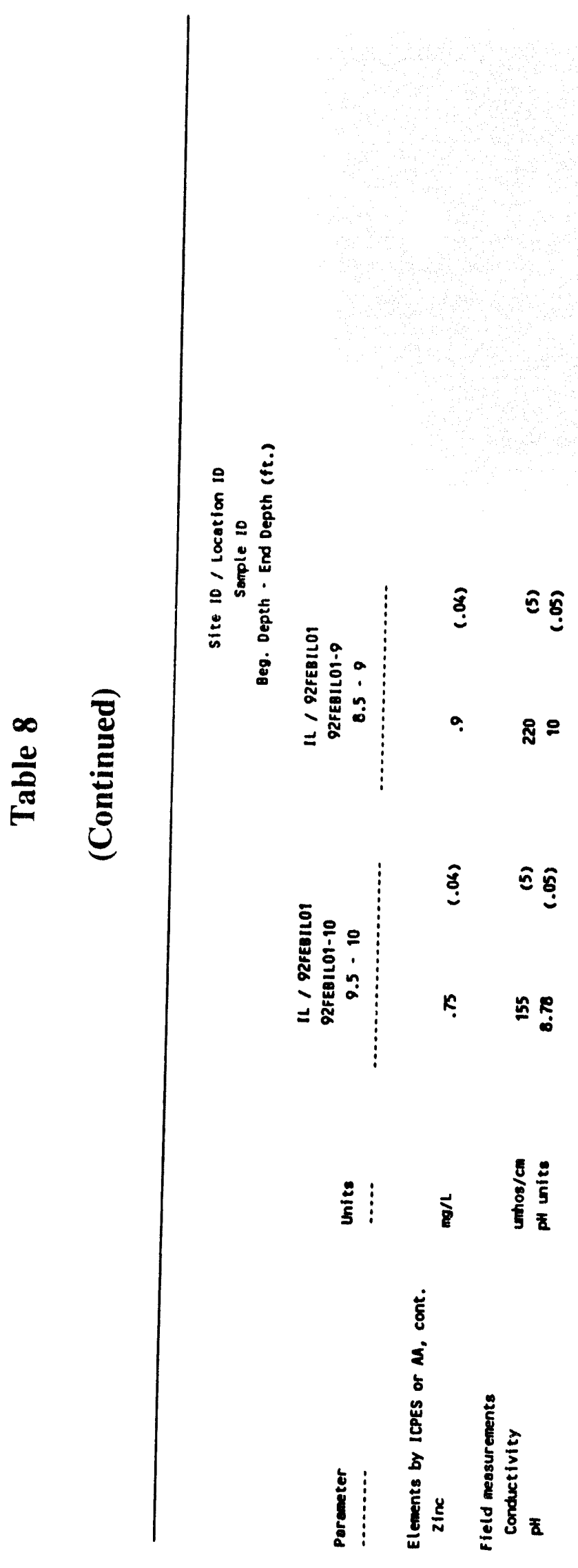




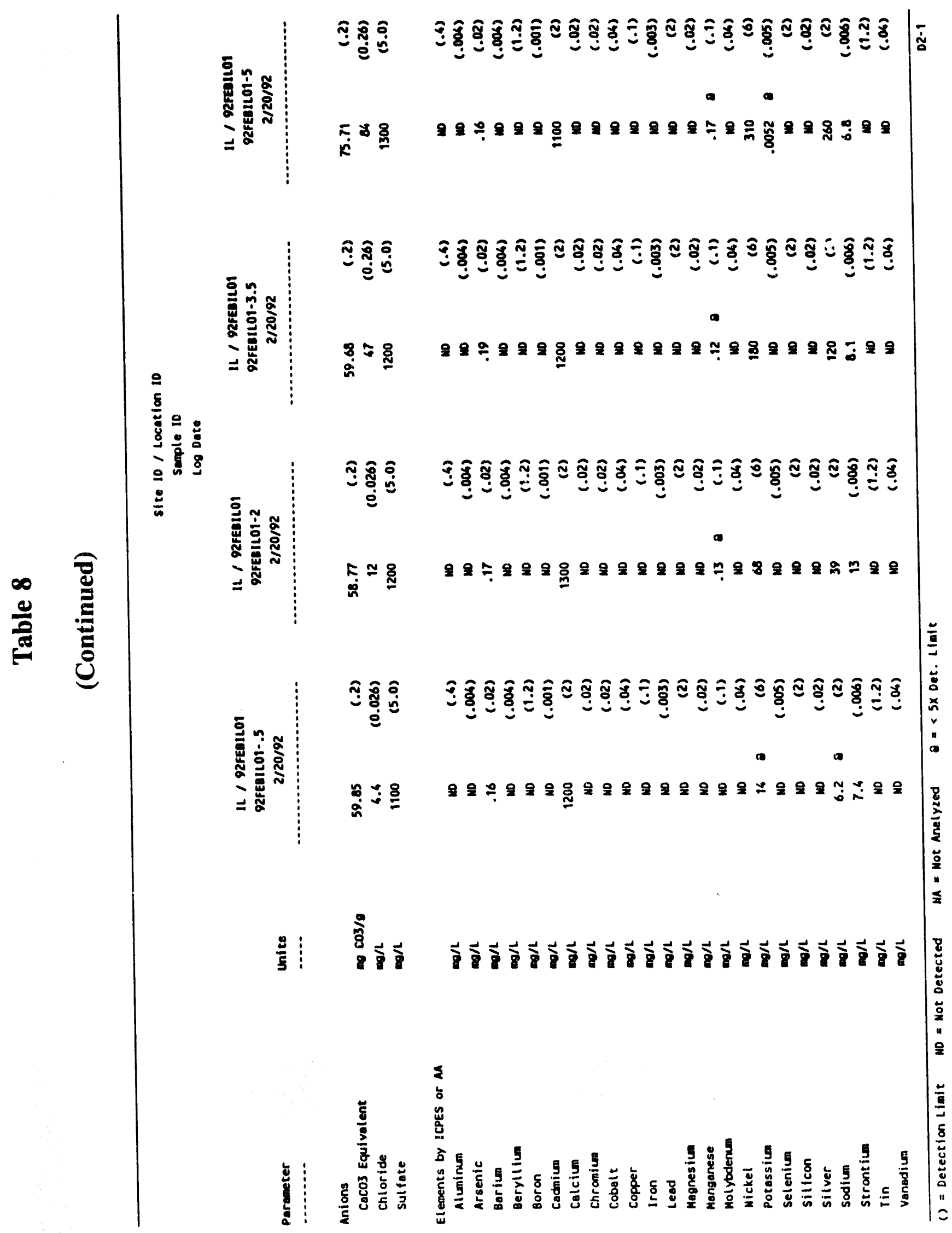



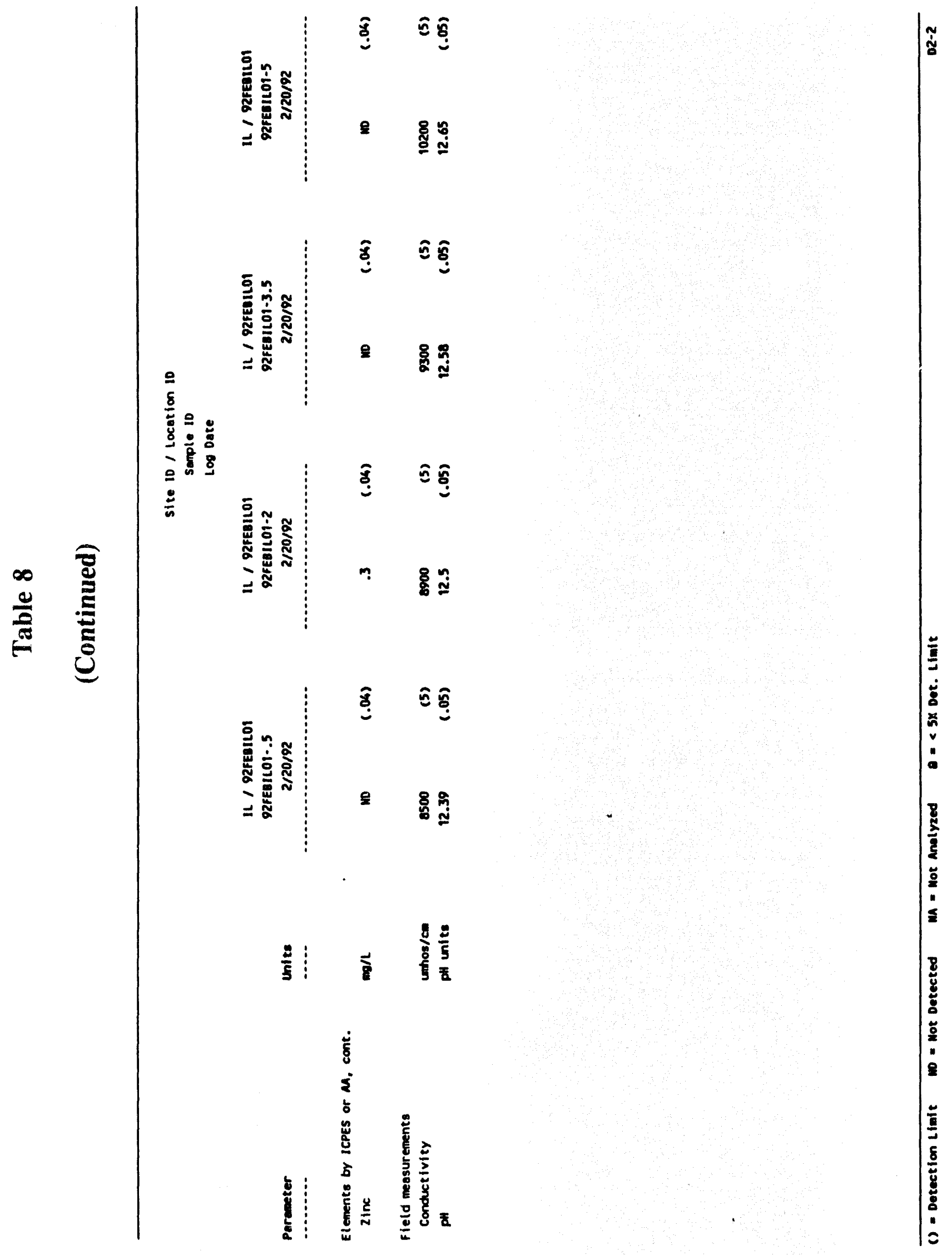


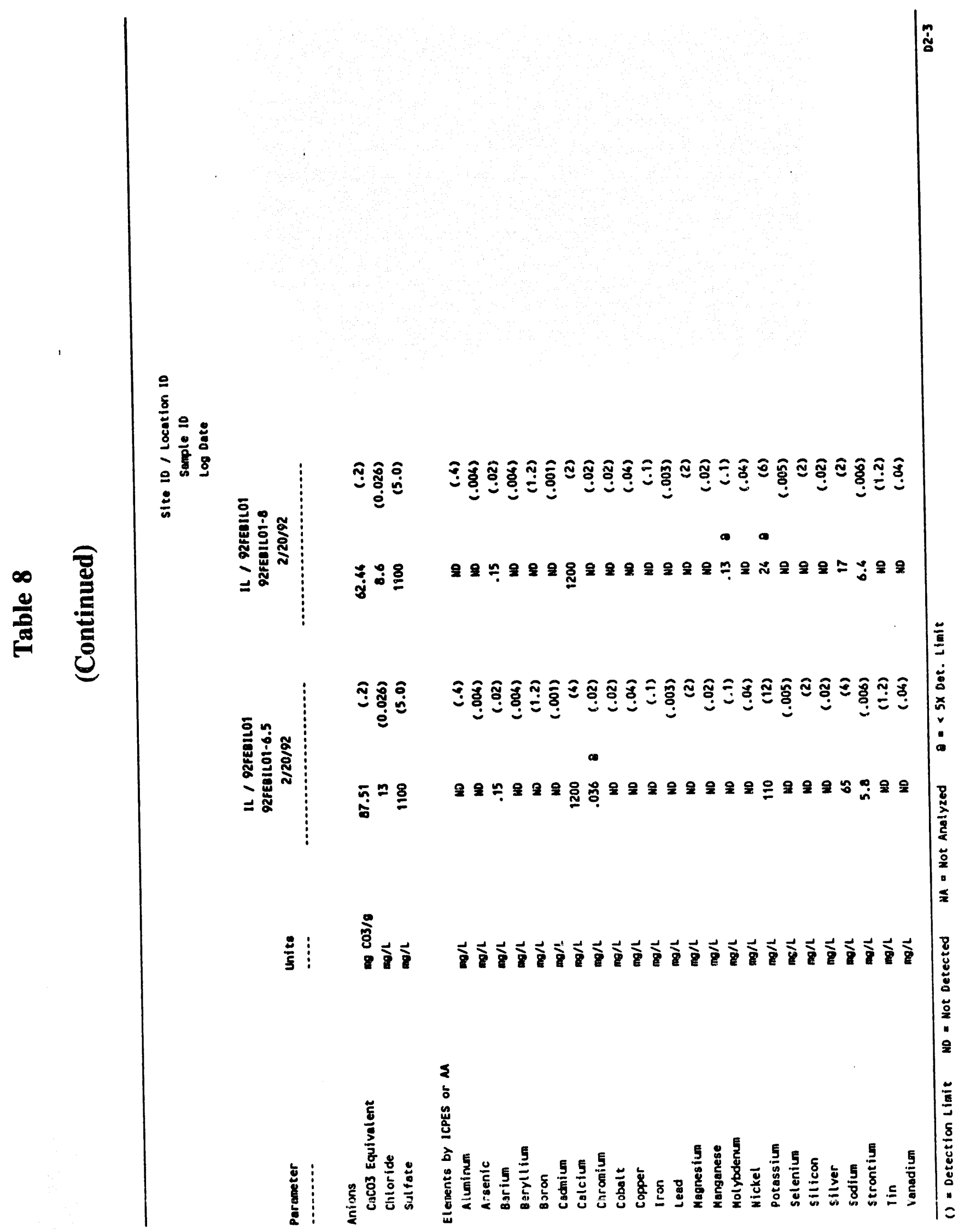




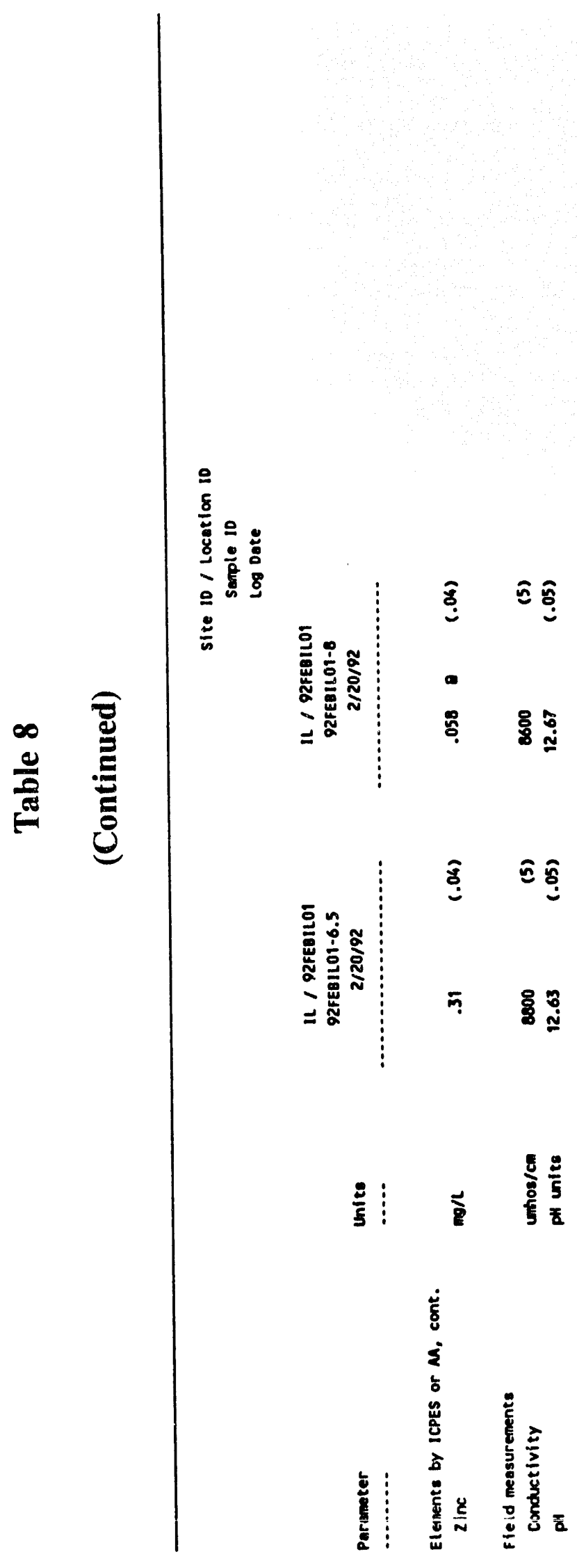




\section{Table 9}

\section{Field Testing - Solid Waste Disposal X-Ray Diffraction Mineralogy - Ash}

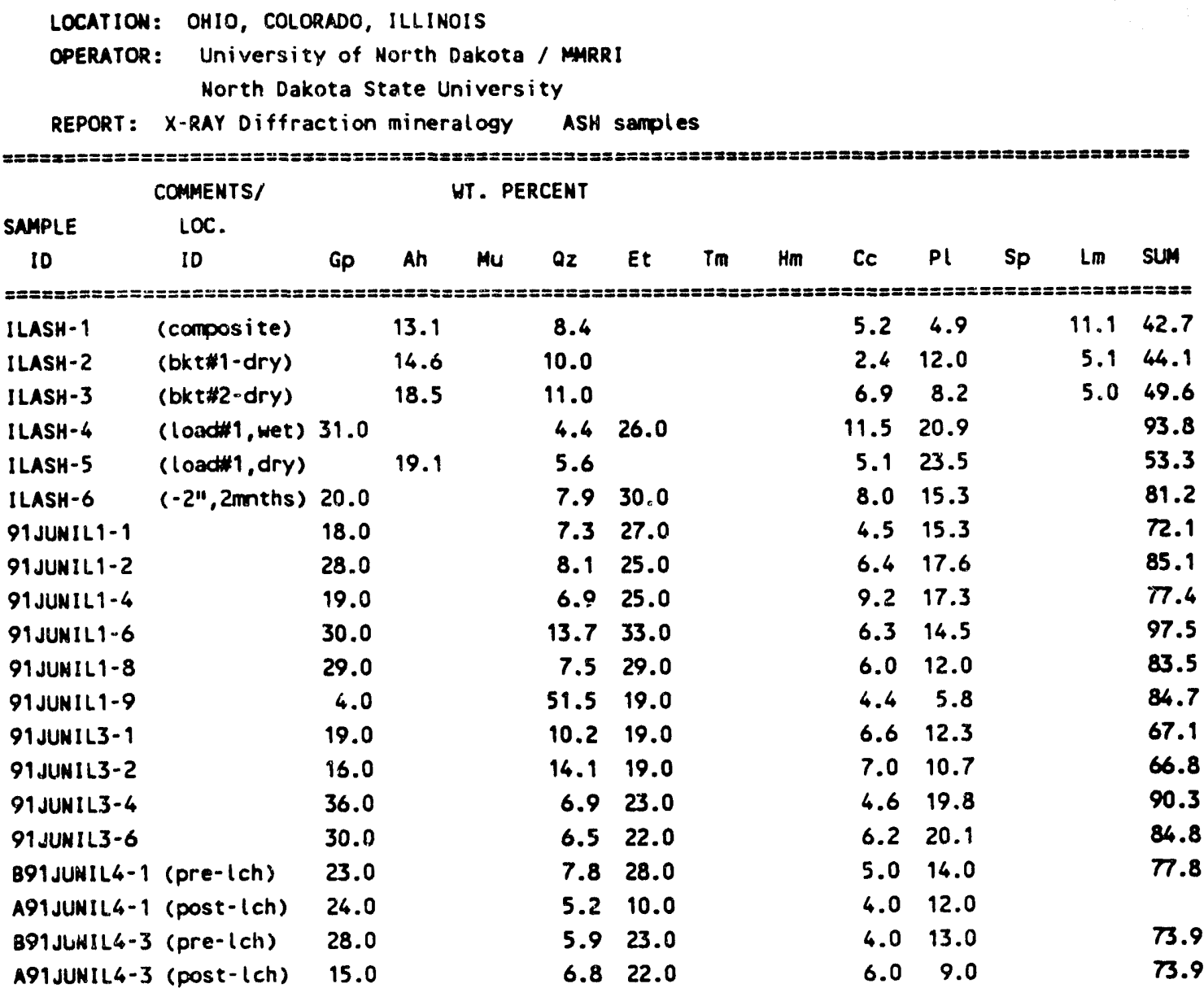

XRD MINERAL KEY

\begin{tabular}{|c|c|c|}
\hline Anhydrite & Ah & CaSO4 \\
\hline Calcite & cc & $\mathrm{CaCO}$ \\
\hline Ettringite & Et & $\mathrm{Ca} 6 \mathrm{Al}(2(\mathrm{SO} 4) \geq(\mathrm{OH}) 12.26 \mathrm{H} 2 \mathrm{O}$ \\
\hline Thaumasite & Tm & $\mathrm{Ca} 6 \mathrm{Si} 2[(\mathrm{SO} 4) 2(\mathrm{CO}) 2](\mathrm{OH}) 12.24 \mathrm{H} 2 \mathrm{O}$ \\
\hline Fe-Spinel & Sp & $\mathrm{Fe} 304$ \\
\hline Gypsum & Gp & $\mathrm{CaSO} 4.2 \mathrm{H} 2 \mathrm{O}$ \\
\hline Hematite & $\mathrm{Hm}$ & $\mathrm{Fe} 203$ \\
\hline Lime & Lm & $\mathrm{CaO}$ \\
\hline Mullite & Mu & Al6si2013 \\
\hline Portlandite & Pl & $\mathrm{Ca}(\mathrm{OH}) 2$ \\
\hline Quartz & 02 & sio2 \\
\hline
\end{tabular}




\section{Table 10}

\section{Field Testing - Solid Waste Disposal \\ In-Situ Hydraulic Conductivity}

LOCATION: ILLINOIS - HOrth cell

REPORT: - In Situ permeabilities

INSTRUMENT: GUELPH Constant head Hell Permeameter [CHUP]

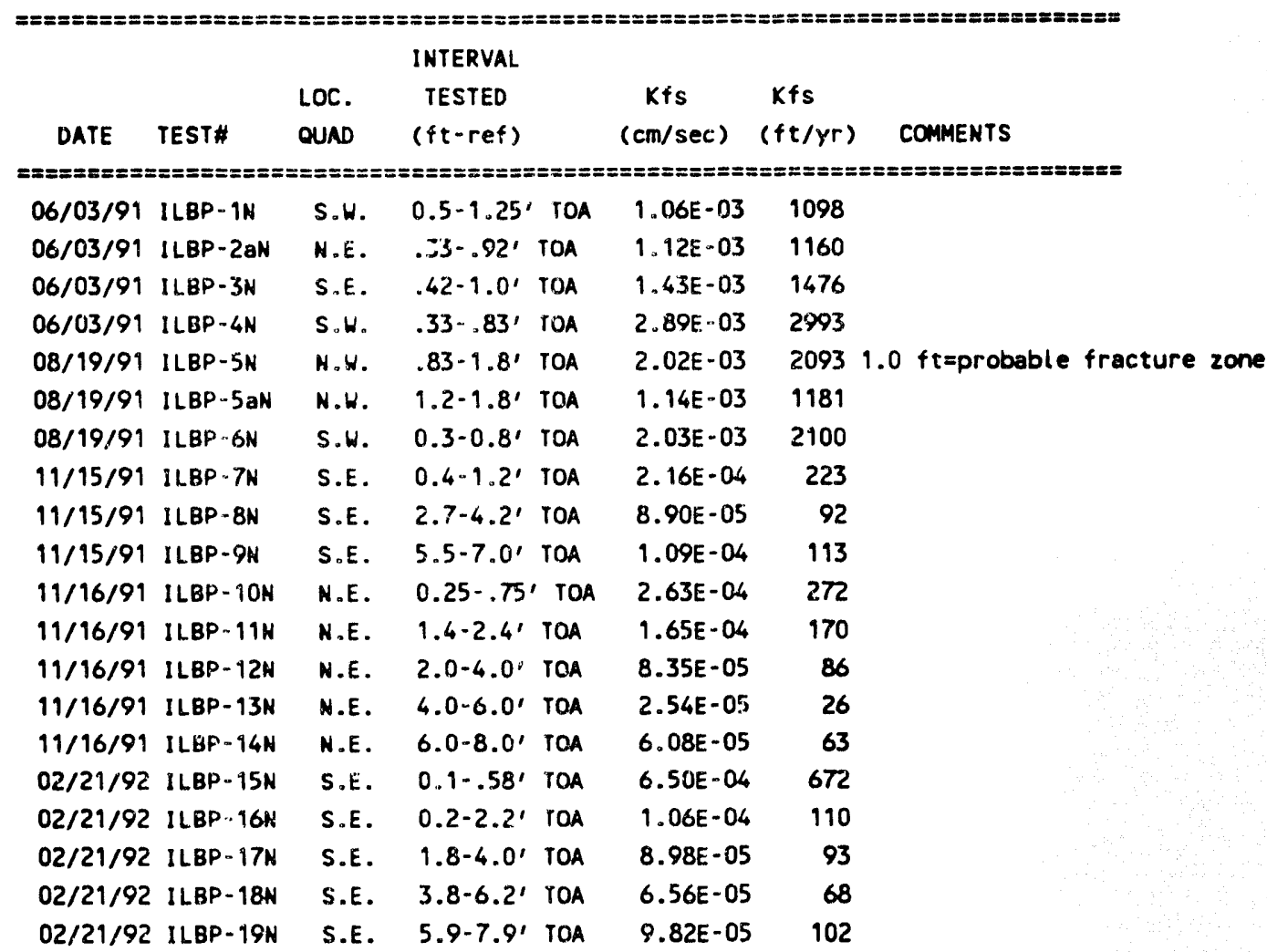

TOA = Top of Ash is used as a reference point for measured depth. 


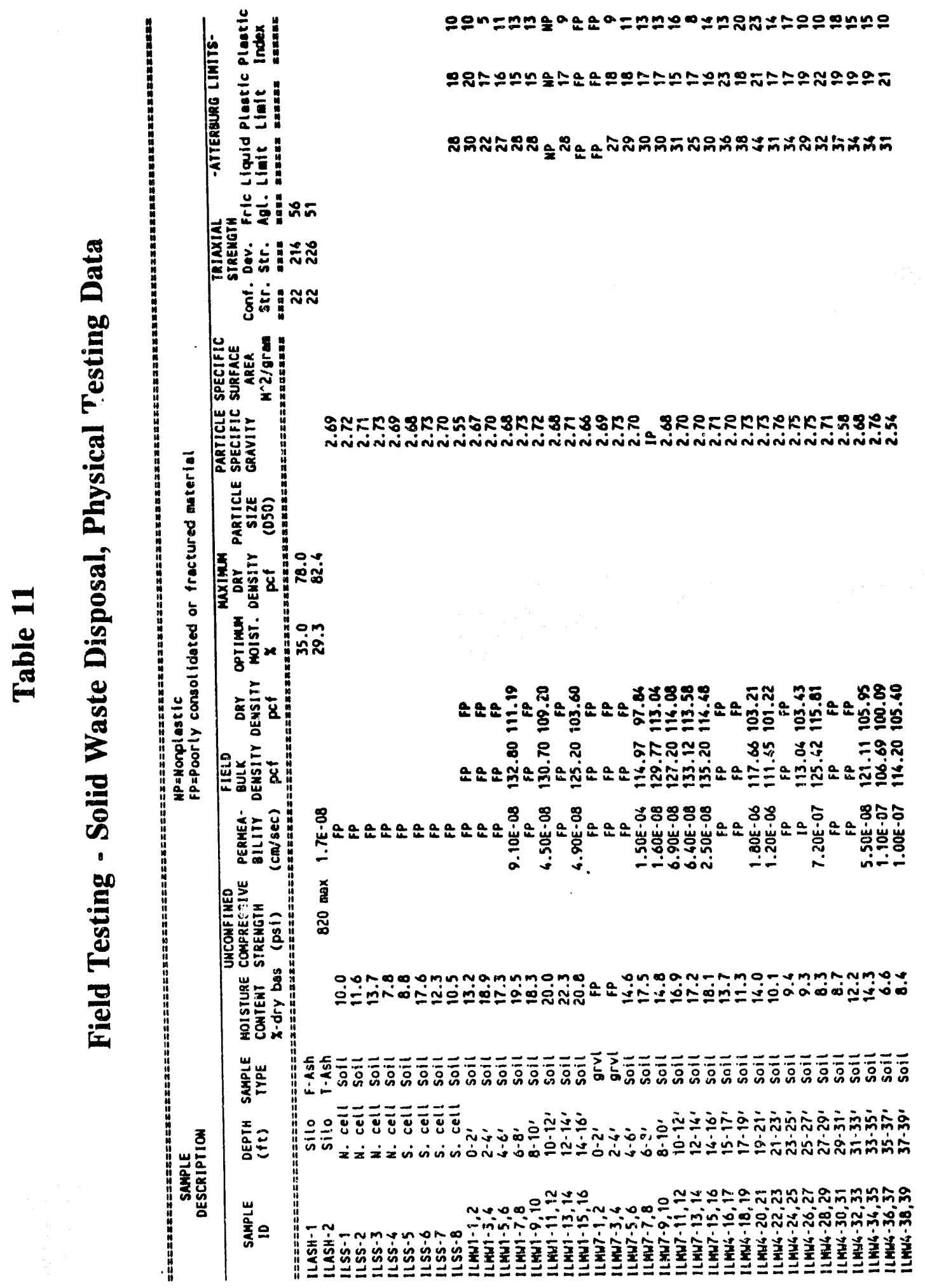




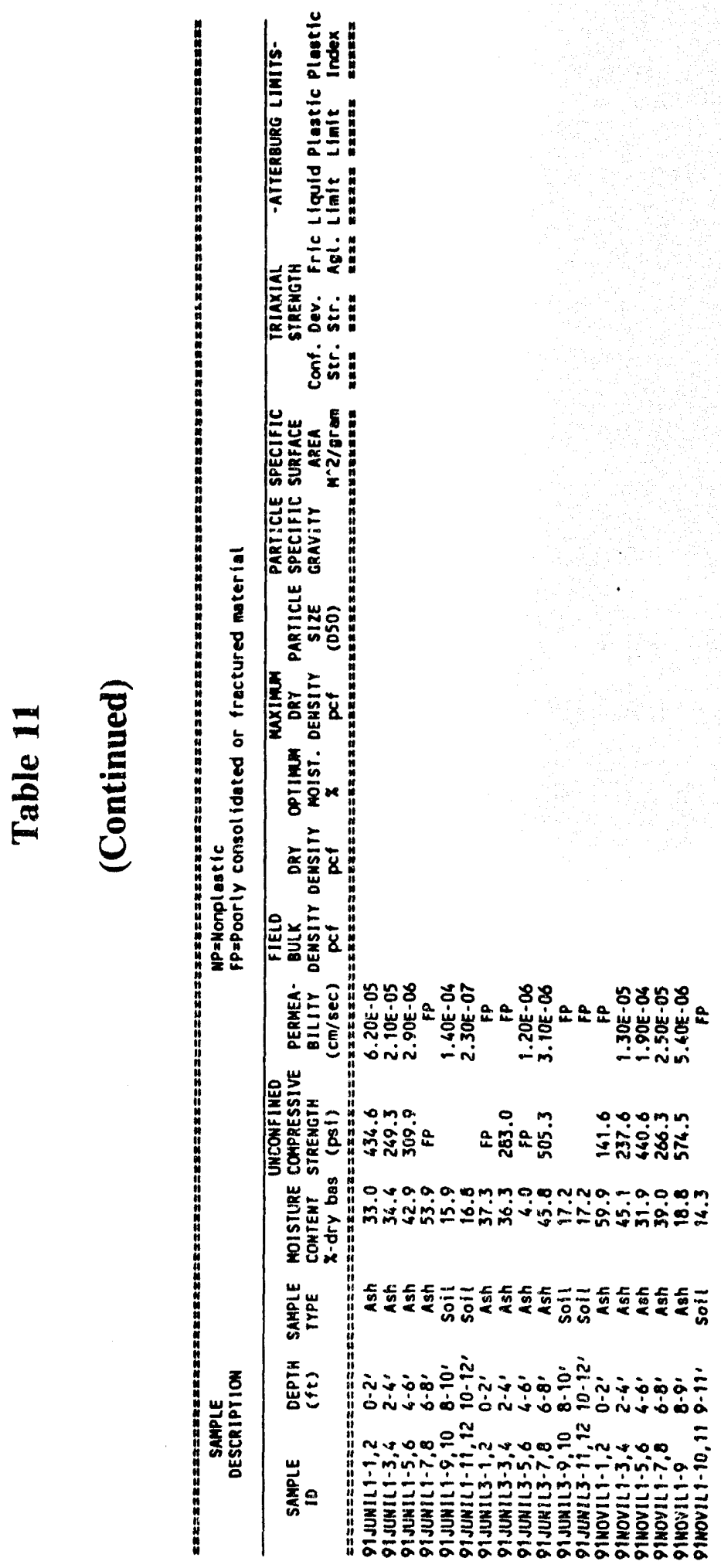




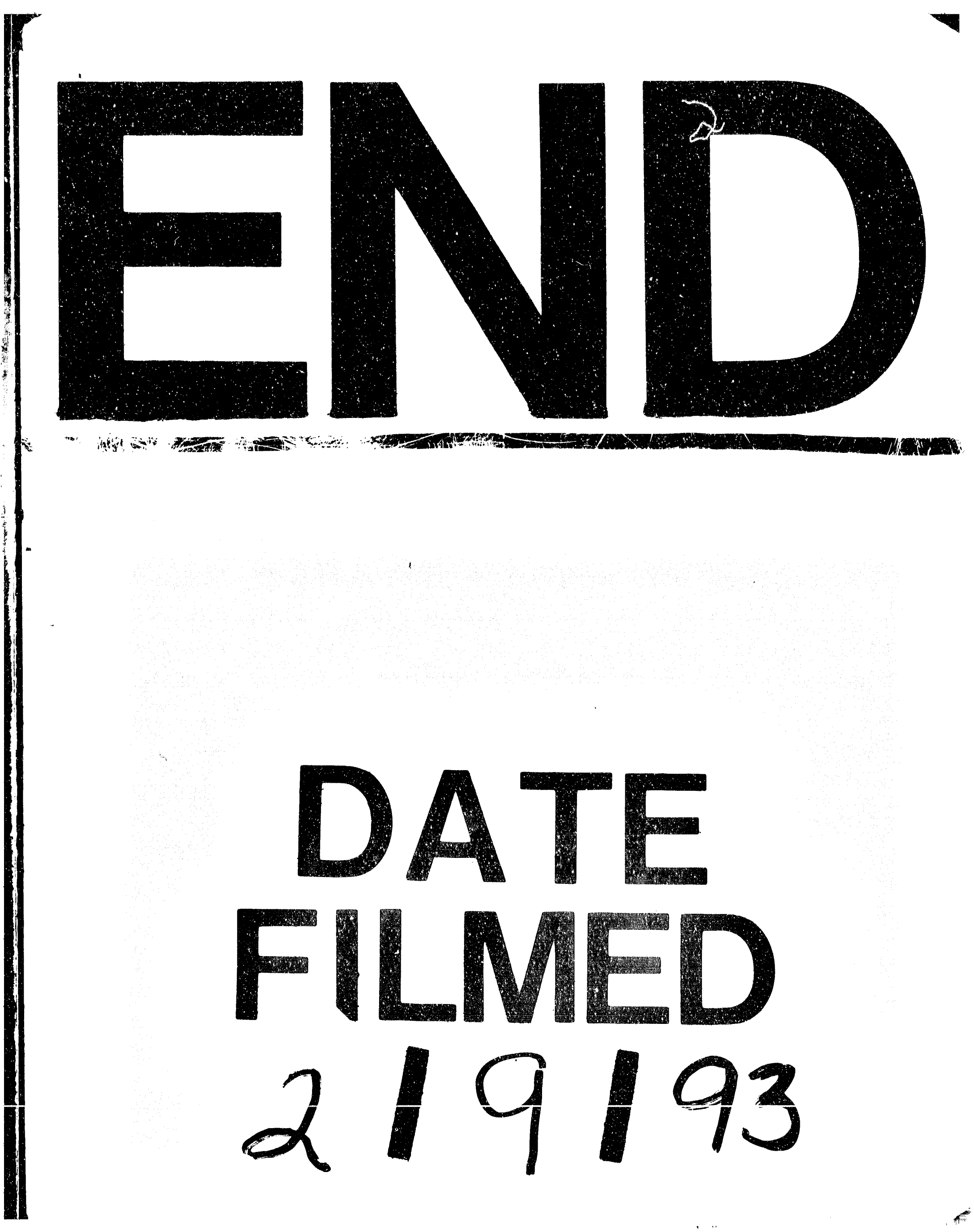




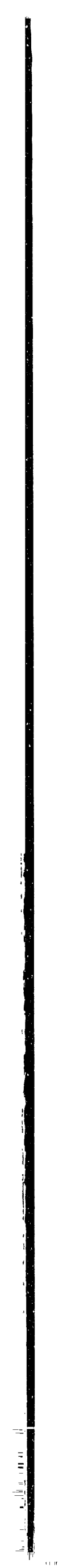

